\title{
Vitamin D derivatives potentiate the anticancer and anti-angiogenic activity of tyrosine kinase inhibitors in combination with cytostatic drugs in an A549 non-small cell lung cancer model
}

\author{
EWA MAJ $^{1}$, BEATA FILIP-PSURSKA ${ }^{1}$, MAGDALENA MILCZAREK $^{1}$, \\ MATEUSZ PSURSKI $^{1}$, ANDRZEJ KUTNER ${ }^{2}$ and JOANNA WIETRZYK ${ }^{1}$ \\ ${ }^{1}$ Hirszfeld Institute of Immunology and Experimental Therapy, Polish Academy of Sciences, \\ 53-114 Wroclaw; ${ }^{2}$ Pharmaceutical Research Institute, 01-793 Warsaw, Poland
}

Received August 24, 2017; Accepted November 17, 2017

DOI: 10.3892/ijo.2017.4228

\begin{abstract}
Numerous in vitro and in vivo studies have demonstrated that calcitriol $\left[1,25(\mathrm{OH})_{2} \mathrm{D}_{3}\right]$ and different vitamin $\mathrm{D}$ analogs possess antineoplastic activity, regulating proliferation, differentiation and apoptosis, as well as angiogenesis. Vitamin D compounds have been shown to exert synergistic effects when used in combination with different agents used in anticancer therapies in different cancer models. The aim of this study was to evaluate the mechanisms of the cooperation of the vitamin D compounds $\left[1,24(\mathrm{OH})_{2} \mathrm{D}_{3}\right.$ (PRI-2191) and $1,25(\mathrm{OH})_{2} \mathrm{D}_{3}$ ] with tyrosine kinase inhibitors (imatinib and sunitinib) together with cytostatics (cisplatin and docetaxel) in an A549 non-small cell lung cancer model. The cytotoxic effects of the test compounds used in different combinations were evaluated on A549 lung cancer cells, as well as on human lung microvascular endothelial cells (HLMECs). The effects of such combinations on the cell cycle and cell death were also determined. In addition, changes in the expression of proteins involved in cell cycle regulation, angiogenesis and the action of vitamin D were analyzed. Moreover, the effects of $1,24(\mathrm{OH})_{2} \mathrm{D}_{3}$ on the anticancer activity of sunitinib and sunitinib in combination with docetaxel were examined in an A549 lung cancer model in vivo. Experiments aiming at evaluating the cytotoxicity of the combinations of the test agents revealed that imatinib and sunitinib together with cisplatin or docetaxel exerted potent anti-proliferative effects in vitro on A549 lung cancer cells and in HLMECs; however, $1,24(\mathrm{OH})_{2} \mathrm{D}_{3}$ and $1,25(\mathrm{OH})_{2} \mathrm{D}_{3}$ enhanced the cytotoxic effects
\end{abstract}

Correspondence to: Dr Ewa Maj, Hirszfeld Institute of Immunology and Experimental Therapy, Polish Academy of Sciences, R. Weigla 12, 53-114 Wroclaw, Poland

E-mail: ewa.maj@iitd.pan.wroc.pl

Key words: angiogenesis, drug combinations, non-small cell lung cancer, tyrosine kinase inhibitor, vitamin D compounds only in the endothelial cells. Among the test agents, sunitinib and cisplatin decreased the secretion of vascular endothelial growth factor (VEGF)-A from the A549 lung cancer cells. The decrease in the VEGF-A level following incubation with cisplatin correlated with a higher p53 protein expression, while no such correlation was observed following treatment of the A549 cells with sunitinib. Sunitinib together with docetaxel and $1,24(\mathrm{OH})_{2} \mathrm{D}_{3}$ exhibited a more potent anticancer activity in the A549 lung cancer model compared to double combinations and to treatment with the compounds alone. The observed anticancer activity may be the result of the influence of the test agents on the process of tumor angiogenesis, for example, through the downregulation of VEGF-A expression in tumor and also on the induction of cell death inside the tumor.

\section{Introduction}

Over 100 years ago, lung cancer was a very rare disease. In 1912, Isaac Adler's first monograph 'Primary malignant growths of the lungs and bronchi: a pathological and clinical study' was published, and it focused on lung cancer in which the author analyzed 374 cases of lung cancer (1). Since that time, a significant increase in lung cancer incidence has been observed $(2,3)$. Currently, epidemiological data indicate that lung cancer is the leading cause of cancer-related mortality worldwide, with an estimation of over 1.8 million new diagnosed cases and 1.6 million deaths from lung cancer annually (4). An improvement in the diagnosis and treatment of lung cancer has been achieved over the past decades; however, the 5-year survival rate for this type of cancer is only $18 \%$, which is poor compared with that for other types of cancer (5). Such a poor outcome in lung cancer treatment is a result of the advanced stage of the disease at the time of diagnosis. While early-stage cancer is managed primarily with surgical resection, followed by adjuvant chemotherapy, advanced-stage lung cancer usually remains incurable, with patients being supported only with palliative care. Therefore, a number of treatment concepts and schedules are investigated and being 
developed globally, beginning from basic research aiming at understanding the molecular events driving lung cancer to novel therapeutic approaches and strategies (6).

Over the past decades, much research has focused on the anticancer activity of vitamin $\mathrm{D}$, as it was discovered that calcitriol $\left[1,25(\mathrm{OH})_{2} \mathrm{D}_{3}\right]$, a hormonally active form of vitamin $\mathrm{D}_{3}$, regulates a number of signaling pathways that drive breast cancer, colon cancer, prostate cancer, melanoma and other types of cancer $(7,8) .1,25(\mathrm{OH})_{2} \mathrm{D}_{3}$ and different vitamin $\mathrm{D}$ analogs have also been shown to possess antiproliferative activity against lung cancer cells that express vitamin D receptor (VDR) $(9,10)$. Moreover, studies using animal models have indicated that $1,25(\mathrm{OH})_{2} \mathrm{D}_{3}$ decreases the metastatic potential of Lewis lung cancer (LLC) cells and augment the immune response against cancer $(11,12)$. Other studies have revealed that vitamin D supplementation decreases the frequency of lung cancer induced by using various carcinogens in laboratory animals $(13,14)$. In addition, $1,25(\mathrm{OH})_{2} \mathrm{D}_{3}$ is able to inhibit the metastasis of B16 melanoma cells into the lungs (15).

By regulating proliferation, differentiation and apoptosis, as well as angiogenesis, $1,25(\mathrm{OH})_{2} \mathrm{D}_{3}$ exhibits anti-neoplastic activity (7). 1,25(OH) ${ }_{2} \mathrm{D}_{3}$ influences angiogenesis by exerting direct anti-proliferative effects on tumor-derived endothelial cells or via the downregulation of the expression of vascular endothelial growth factor (VEGF) or interleukin (IL)-8 in several malignant cells (16-18). These data suggest that $1,25(\mathrm{OH})_{2} \mathrm{D}_{3}$ or its analogs may be very important agents in the anti-angiogenic therapy of cancers.

In a number of types of cancer, including non-small cell lung cancer (NSCLC), targeting tumor angiogenesis is widely developed since neovascularization is essential for tumor growth, progression and metastasis (19). One of the main pro-angiogenic pathways described is VEGF signaling (20). There are, in general, two main approaches used in interfering with tumor angiogenesis and these are as follows: i) the use of high molecular weight monoclonal antibodies binding circulating VEGF or its receptors (VEGFRs) present in the cell membranes of endothelial cells; and ii) small-molecule tyrosine kinase inhibitors (TKIs) that bind and block the activity of VEGF receptors (19). Bevacizumab (Avastin, Hoffmann-La Roche Ltd., Basel, Switzerland) is one of the most well-known anti-VEGF monoclonal antibodies. In an Eastern Cooperative Oncology Group (ECOG) clinical trial involving 878 patients with recurrent or advanced NSCLC, bevacizumab in combination with platinum-based chemotherapy was shown to improve survival compared to chemotherapy alone $(21,22)$. In the case of TKIs, there is a growing number of newly synthesized and studied inhibitors that not only target VEGFRs, but also simultaneously target other kinases [e.g., c-kit, platelet-derived growth factor receptor (PDGFR), fibroblast growth factor receptor (FGFR) and RET]. Among these inhibitors, nintedanib was the first agent to demonstrate improved survival in the second-line treatment of patients with adenocarcinoma NSCLC $(19,23)$.

Treatment with sunitinib (inhibitor of VEGFR1-3, PDGFR $\alpha$ and $\beta$ RET) and other multi-target drugs, is accompanied by certain adverse effects (19). Therefore, combining sunitinib at lower doses with other chemotherapeutic agents may be used to avoid undesirable side-effects, while revealing synergistic activity (24). Second, tumors develop resistance to anti-angiogenic treatment, activating alternative pathways that promote angiogenesis; therefore, studies on drug combinations targeting several signaling pathways may provide means of better controlling tumor angiogenesis (25). Third, despite the introduction of anti-angiogenic drugs to clinical practice, there has still been a high failure rate of trials with anti-angiogenic agents. Due to the heterogeneous nature of lung cancer in NSCLC, some patients are more likely to respond to antiangiogenic drugs than others, which may explain the failure of some clinical trials (19 and refs therein).

Vitamin D compounds have been previously tested in our laboratory for their anti-proliferative and anticancer activities in different cancer models both in vitro and in vivo, mainly in breast cancer, colorectal cancer and leukemia, where vitamin D analogs exhibited anticancer activity alone or potentiated the activity of standard cytostatics (26-32). In the present study, we wished to examine the activity of the vitamin $\mathrm{D}$ compounds, $1,24(\mathrm{OH})_{2} \mathrm{D}_{3}(\mathrm{PRI}-2191)$ and $1,25(\mathrm{OH})_{2} \mathrm{D}_{3}$, in combination with two TKIs (imatinib and sunitinib) and two cytostatic drugs (cisplatin and docetaxel) in A549 lung cancer cells and human lung microvascular endothelial cells (HLMECs).

\section{Materials and methods}

Cell culture. The lung cancer cell line, A549, was obtained from the American Type Culture Collection (ATCC, Bethesda MD, USA). HLMECs (which had been already immortalized by transfection with pSV3-neoplasmid containing large T-antigen gene) were a kind gift from Professor Claudine Kieda (Center for Molecular Biophysics, Orleans, France) (33). The cell lines were maintained at the Cell Culture Collection Division of Hirszfeld Institute of Immunology and Experimental Therapy, Polish Academy of Sciences in Wroclaw, Poland. The A549 cells were cultured in OptiMEM + RPMI-1640 (1:1) medium [PChO; Institute of Immunology and Experimental Therapy (IIET), Polish Academy of Sciences (PAS), Wroclaw, Poland], containing 5\% fetal bovine serum (FBS) and $2 \mathrm{mM}$ L-glutamine (Sigma-Aldrich, Steinheim, Germany). The HLMECs were cultured in RPMI-1640 (PChO, IIET, PAS, Wroclaw, Poland) with the addition of $10 \%$ FBS and $2 \mathrm{mM}$ L-glutamine (Sigma-Aldrich). Both culture media were supplemented with the following antibiotics: streptomycin and penicillin (Polfa Tarchomin, Warsaw, Poland). The cells were cultured in an auto flow water jacket $\mathrm{CO}_{2}$ incubator (NuAire, Plymouth, MN, USA) at $37^{\circ} \mathrm{C}$ and in a humidified atmosphere saturated with $5 \% \mathrm{CO}_{2}$.

Compounds. Vitamin $\mathrm{D}_{3}$ metabolites, such as calcitriol [1,25-dihydroxy vitamin $\left.\mathrm{D}_{3}, 1,25(\mathrm{OH})_{2} \mathrm{D}_{3}\right]$ and PRI-2191 (24R)-1,24-dihydroxy vitamin $\mathrm{D}_{3}\left[1,24(\mathrm{OH})_{2} \mathrm{D}_{3}\right.$, tacalcitol] (31) were certified synthetic materials provided by the Pharmaceutical Research Institute (Warsaw, Poland). Imatinib mesylate (also termed Gleevec or GV) was obtained from the Pharmaceutical Research Institute. Sunitinib malate (also termed SU) and docetaxel (also termed DTX) were obtained from AK Scientific Inc. (Union City, CA, USA). Cisplatin (also termed CIS) was obtained from Accord Healthcare Poland (Warsaw, Poland). 
Prior to in vitro usage, the vitamin $\mathrm{D}$ compounds were dissolved in $99.8 \%$ ethanol (Avantor, Gliwice, Poland). Imatinib mesylate was dissolved in aqua pro injection (Polpharma, Starogard Gdanski, Poland). Sunitinib malate and docetaxel were dissolved in dimethyl sulfoxide (DMSO) (Avantor).

Prior to in vivo usage, the vitamin $\mathrm{D}$ analog $1,24(\mathrm{OH})_{2} \mathrm{D}_{3}$ was dissolved in $99.8 \%$ ethanol (Avantor), then diluted in $80 \%$ polyethylene glycol (Sigma-Aldrich) to reach the required concentrations, and then administered to mice at a volume of $5 \mu \mathrm{l} / \mathrm{g}$ /body weight. SU was diluted in $0.1 \mathrm{M}$ citrate buffer ( $\mathrm{pH} 3.5)$ (PChO, IIET PAS) to reach the required concentrations and was administered to mice at a volume of $10 \mu \mathrm{l} / \mathrm{g} / \mathrm{body}$ weight. DTX was dissolved in a mixture of cremophor + ethanol $(0.36 \mathrm{ml}+0.64 \mathrm{ml})$ and then in saline (1:9) (cremophor from Sigma-Aldrich; ethanol 96\% from Avantor; saline from PChO, IIET PAS) and was administered to the mice at a volume of $10 \mu \mathrm{l} / \mathrm{g} /$ body weight.

Determination of anti-proliferative activity. Using sulforhodamine B (SRB) assay, the cytotoxic activity of the test compounds and their combinations against the A549 cells and HLMECs was evaluated. First, the cells were exposed to each agent alone in the range of serial dilutions for $72 \mathrm{~h}$. Simultaneously, the cells were exposed to solvents used, such as EtOH and DMSO (Avantor) in the same serial dilutions as with the test agents. Following incubation, cells were fixed with $50 \%$ trichloroacetic acid (TCA) (Avantor) for $1 \mathrm{~h}$ followed by washing with tap water. The cells were then stained for $30 \mathrm{~min}$ with $0.1 \%$ SRB (Sigma-Aldrich) in $1 \%$ acetic acid (Avantor); the excess of SRB was washed out with $1 \%$ acetic acid. The dye bound to the cells was extracted with $10 \mathrm{mM}$ TRIS-base [Tris(hydroxymethyl)aminomethane] (Sigma-Aldrich), and the absorbance of each solution was measured at $540 \mathrm{~nm}$ wavelength in Synergy H4 Hybrid Multi-Mode microplate reader (BioTek Instruments, Inc., Winooski, VT, USA). Using Cheburator 0.4, Dmitry Nevozhay software, the 50\% inhibitory concentration $\left(\mathrm{IC}_{50}\right)$ was calculated, as previously described (34). Based on the calculated $\mathrm{IC}_{50}$ value, the concentrations of a given TKI and cytostatic were set following the rule of 'fixed constant ratio' $(35,36)$. Vitamin D compounds were used at the concentration of $100 \mathrm{nM}$. The cells were then exposed to various combinations of each vitamin D compound with each TKI and/or cytostatic tested for $72 \mathrm{~h}$; using SRB assay, the anti-proliferative activity was measured again, and the proliferation inhibition was calculated as follows: $\%$ proliferation inhibition $=-\left[\left(\mathrm{Abs}_{\text {control }}-\mathrm{Abs}_{\mathrm{med}}\right) /\left(\mathrm{Abs}_{\text {test }}-\mathrm{Abs}_{\mathrm{med}}\right)\right.$ $\mathrm{x} 100-100]$, where Abs ${ }_{\text {control }}$ is the absorbance of the control cells, Abs ${ }_{\text {med }}$ is the absorbance of the culture medium and Abs test is the absorbance for the test agent or combination treatment.

The experiments were repeated at least thrice in separate courses. Based on the calculated percentage of proliferation inhibition, the effects of the combination of the test compounds (synergism, additive effect and antagonism) were assessed using the combination index (CI) calculated as previously described by Chou and Talalay $(37,38)$ with CalcuSyn Version 2.1 software (Biosoft, Cambridge, UK). If the $\mathrm{CI}>1.2$, the effect observed was antagonistic, and the $\mathrm{CI}$ from the range of 0.8-1.2 depicted an additive effect and a CI $<0.8$ depicted synergism.
Cell cycle and cell death analysis. The A549 cells and HLMECs were seeded in 24-well plates (Corning Inc., Corning NY, USA) in culture medium. After $24 \mathrm{~h}$, the compounds in different combinations were added and the cells were exposed to these compounds for $72 \mathrm{~h}$. The cells were then collected, washed in phosphate-buffered saline (PBS) $(\mathrm{PChO}$, IIET PAS), and preserved in $70 \%$ ethanol (Avantor) at $-20^{\circ} \mathrm{C}$ for at least $24 \mathrm{~h}$. The cells were then washed in PBS and then incubated at $+37^{\circ} \mathrm{C}$ for $1 \mathrm{~h}$ with $8 \mu \mathrm{g} / \mathrm{ml}$ RNase (Thermo Fisher Scientific, Waltham MA, USA). Subsequently, the cells were incubated for $30 \mathrm{~min}$ with $50 \mu \mathrm{l}$ of $0.1 \mathrm{mg} / \mathrm{ml}$ propidium iodide (Sigma-Aldrich) and analyzed using a flow cytometer BD LSR Fortessa with FACS Diva Software (Becton-Dickinson, San Jose, CA, USA). The experiment was repeated at least thrice.

Caspase-3 activity assay. Caspase-3 activity was analyzed based on its enzymatic activity of the hydrolysis of synthetic substrate Ac-DEVD-ACC leading to the release of 7-aminocoumarin fluorochrome, with the measurement of the fluorescence intensity in time (39). Therefore, the A549 cells and HLMECs were seeded in 24-well plates, and after $24 \mathrm{~h}$, the test compounds were added to the cells alone or in different combinations for $72 \mathrm{~h}$. The culture medium was then discarded and the cells were lysed for $30 \mathrm{~min}$ at $+4^{\circ} \mathrm{C}$ in $50 \mathrm{mM}$ HEPES buffer ( $\mathrm{pH} 7.5$ ) containing $10 \%$ saccharose, $150 \mathrm{mM} \mathrm{NaCl}, 5 \mathrm{mM}$ EDTA, $10 \mathrm{mM}$ DL-dithiothreitol (DTT), 0.1\% Triton X-100 (DTT was added ex tempore) (Sigma-Aldrich). The $20 \mathrm{mM}$ HEPES reaction buffer ( $\mathrm{pH} 7.5)$ containing $10 \%$ saccharose, $100 \mathrm{mM} \mathrm{NaCl}, 1 \mathrm{mM}$ EDTA and $10 \mathrm{mM}$ DTT (DTT was added ex tempore) and $10 \mu \mathrm{M}$ Ac-DEVD-ACC synthetic substrate (added ex tempore) (Wroclaw University of Technology, Wroclaw, Poland) were prepared and warmed up to $+37^{\circ} \mathrm{C}$ in dark prior to use. Subsequently, $40 \mu \mathrm{l}$ of each cell lysate were transferred to 96-well white plates (Corning, Amsterdam, The Netherlands), followed by the addition of $160 \mu \mathrm{l}$ Ac-DEVD-ACC containing reaction buffer. The increase in fluorescence intensity was measured at $\lambda=355$ and $\lambda=460 \mathrm{~nm}$ within $2 \mathrm{~h}$ every $10 \mathrm{~min}$ at $+37^{\circ} \mathrm{C}$ in Synergy $\mathrm{H} 4$ Hybrid Multi-Mode microplate reader with Gen5 1.11.5 software (BioTek Instruments, Inc.). The kinetic of the reaction was calculated as relative fluorescence units (RFU)/min. In order to normalize the obtained results of caspase-3 activity to the number of cells, SRB assay was performed in parallel 24-well plates of cultured cells exposed to analogous combinations of the test compounds for $72 \mathrm{~h}$. Experiments were repeated at least thrice in separate courses.

Western blot analysis. The A549 cells and HLMECs exposed for $72 \mathrm{~h}$ to different combinations of GV, SU, CIS, DTX and vitamin D compounds were lysed in RIPA buffer (Sigma-Aldrich) supplemented with protease and phosphatase inhibitor cocktails (Sigma-Aldrich) followed by centrifugation for $10 \mathrm{~min}$ at $+4^{\circ} \mathrm{C}$ and $11,000 \mathrm{x}$ g. Tumors harvested from the mice (see below) following storage at $-80^{\circ} \mathrm{C}$ were homogenized (Tissue and Cell Homogenizer FastPrep-24, MP Biomedicals, Warsaw, Poland) in RIPA buffer containing protease inhibitor cocktail (Sigma-Aldrich). The homogenates were then centrifuged twice for $10 \mathrm{~min}$ at $+4^{\circ} \mathrm{C}$ and $11,000 \mathrm{x} \mathrm{g}$ and the supernatants were then transferred to new tubes. 
The total protein concentration in the cell and tissue lysates was measured using the modified Lowry method (Bio-Rad, Warsaw, Poland).

Approximately $30 \mu \mathrm{g}$ (in vitro) or $100 \mu \mathrm{g}$ (in vivo) of protein were denatured in Laemmli buffer (Bio-Rad, Warsaw, Poland) supplemented with $\beta$-mercaptoethanol (Sigma-Aldrich) for $5 \mathrm{~min}$ at $+95^{\circ} \mathrm{C}$ and were then loaded onto SDS-PAGE gels. Following electrophoresis, proteins were transferred from gels onto PVDF membranes (GE Healthcare UK Ltd., Little Chalfont, UK). After blocking in 5\% non-fat dry milk in PBS, the membranes were probed for $1 \mathrm{~h}$ at room temperature with the following primary antibodies (antibodies dilution 1:200 in PBS-Tween-20): anti-Bax (sc-493), anti-Bcl-2 (sc-783), anti-VDR (sc-1008), for actin (1:500), anti-CYP24 (sc-66851), anti-CYP27B1 (sc-67261), anti-p21 (sc-397), anti-p53 (sc-6243), anti-phosphatase and tensin homolog (PTEN) (sc-9145), anti-nuclear factor (NF) $\kappa \mathrm{B}$ (sc-114), anti-I $\mathrm{B}$ (sc-371), and anti-actin (sc-1616-R) (Santa Cruz Biotechnology, Santa Cruz CA, USA). Following incubation with the primary antibodies, the PVDF membranes were washed thrice for $10 \mathrm{~min}$ in PBS-Tween-20 (PBS from PChO, IIET, PAS; Tween-20 from Sigma-Aldrich) and were then incubated for $1 \mathrm{~h}$ at room temperature with alkaline phosphatase-conjugated secondary antibody (RPN5783) (antibody dilution 1:10,000 in PBS-Tween-20) (GE Healthcare UK Ltd.). Following incubation with the secondary antibody and washing in PBS-Tween-20 (3x10 min), protein bands were visualized with an enhanced chemifluorescence kit (GE Healthcare UK Ltd.). Images were acquired with a Carestream Image Station 4000MM PRO (Carestream Molecular Imaging, Woodbridge, CT, USA). Western blot analysis was repeated 2-4 times. Densitometric analysis of the western blots was performed using Image J 1.48v software (National Institutes of Health, Bethesda, MA, USA). The results were normalized to actin.

Immunofluorescence staining. The A549 cells were cultured on sterile cover glass (12-mm in diameter) (Menzel-Gläser, Thermo Fisher Scientific, Waltham, MA, USA), placed into 24-well plates, and exposed for $72 \mathrm{~h}$ to different combinations of GV, SU, CIS, DTX and vitamin D compounds. The cells were then washed in PBS and fixed in cold acetone:methanol (1:1) (Avantor) at $-20^{\circ} \mathrm{C}$, permeabilized in $0.5 \%$ PBS-Triton $\mathrm{X}-100$ (Sigma-Aldrich), washed in 0.1\% PBS-Triton X-100 and blocked in $2 \%$ FBS in PBS (Sigma-Aldrich). Subsequently, the cells were incubated with anti-p53 antibody at room temperature (sc-6243, Santa Cruz Biotechnology, Santa Cruz, CA, USA), washed in $0.1 \%$ PBS-Triton X-100, and incubated with FITC-conjugated secondary antibody (sc-2365, Santa Cruz Biotechnology). After the next wash, the cell nucleus was stained with 4',6-diamidino-2-phenylindole dihydrochloride (DAPI) (Life Technologies, Carlsbad, CA, USA) and the cells were embedded in anti-fade mounting medium (Santa Cruz Biotechnology). The slides were examined under a fluorescence microscope with CellSens software (Olympus, Warsaw, Poland).

Real-time PCR analysis. The A549 cells exposed to the test compounds and their combinations were collected in TRI Reagent (Sigma-Aldrich) and kept at $-80^{\circ} \mathrm{C}$ for further analysis. After thawing, chloroform (Avantor) was added to each test tube, following by shaking and centrifugation $\left(12,000 \times \mathrm{g},+4^{\circ} \mathrm{C}, 15 \mathrm{~min}\right)$, and the obtained water phase was transferred to clean test tubes and total RNA was precipitated with isopropanol (POCH, Gliwice, Poland). Following centrifugation, the pellet of RNA was washed in $75 \%$ ethanol (Avantor); the RNA was allowed to dry, and the pellet of RNA was dissolved in DEPC (Sigma-Aldrich). The RNA concentration was measured using a NanoDrop 2000 UV-Vis spectrophotometer (Thermo Fisher Scientific, Wilmington, DE, USA). Approximately, $1 \mu \mathrm{g}$ RNA of each sample was incubated with DNase (Invitrogen, Carlsbad CA, USA) and RNase inhibitor (EURx, Gdansk, Poland) at $+37^{\circ} \mathrm{C}$ in Veritii 9902 thermocycler (Life Technologies) for $15 \mathrm{~min}$ and cDNA was synthesized using iScript kit (Bio-Rad, Hercules, CA, USA) according to the following steps: $5 \mathrm{~min}+25^{\circ} \mathrm{C}, 30 \mathrm{~min}+42^{\circ} \mathrm{C}$, $5 \mathrm{~min}+85^{\circ} \mathrm{C}$, and cooling down to $+4^{\circ} \mathrm{C}$. Samples were stored for further analysis at $-20^{\circ} \mathrm{C}$. Using real-time PCR, the expression of MYC (Hs00153408_m1, Life Technologies), VEGFA (Hs00900055_m1, Life Technologies), and TP53 (Hs00153349_m1, Life Technologies) was analyzed with the use of TaqMan probes and Master Mix (Life Technologies) in Viia 7 Real-Time PCR System with Viia 7 Software v1.1 (Life Technologies) as follows: $2 \mathrm{~min}+50^{\circ} \mathrm{C}, 10 \mathrm{~min}+95^{\circ} \mathrm{C}$; 40 cycles, $15 \mathrm{sec}+95^{\circ} \mathrm{C}, 1 \mathrm{~min}+60^{\circ} \mathrm{C}$. The $\Delta \Delta \mathrm{CT}$ method was used to calculate the relative changes in gene expression. Results were analyzed in Expression Suite Software v1.0.3 (Life Technologies) and the level of expression was normalized to RPLP0 (Hs99999902_m1, Life Technologies).

$P D G F-B B$ and VEGF-A ELISA. The levels of PDGF-BB and VEGF-A in tumor lysates, prepared as described for western blot analysis, were then assessed using commercially available ELISA kits (eBiosciences, Vienna, Austria and Invitrogen, Camarillo CA, USA, respectively), following the manufacturer's instructions. The absorbance of probes obtained at the end of the procedure was measured at $450 \mathrm{~nm}$ using Synergy H4 Hybrid Multi-Mode Microplate Reader with software Gen5 (BioTek Instruments, Inc.). The calculated cytokine level was then normalized in each sample to the total protein concentration. In addition, the VEGF-A level was measured in conditioned medium obtained from the A549 cells. For this purpose, the A549 cells were exposed in vitro to the test combinations of GV, SU, CIS, DTX and vitamin D compounds $\left[1,25(\mathrm{OH})_{2} \mathrm{D}_{3}\right.$ and $\left.1,24(\mathrm{OH})_{2} \mathrm{D}_{3}\right]$ for $72 \mathrm{~h}$ and then washed with PBS and incubated with RPMI-1640 medium without FBS and phenol red for $48 \mathrm{~h}$ (PChO, IIET PAS). Subsequently, conditioned medium was collected, and to include the number of cells in each well, SRB assay was performed to assess the proliferation inhibition of the test compounds and their combination. The experiment was repeated thrice.

Establishment of mouse xenograft A549 tumor model. The study involving the use of laboratory animals was performed following the approval of The First Local Ethical Committee for Experiments with the Use of Laboratory Animals, Wroclaw, Poland (LKE approval no.: 41/2011, 28/2013 and 29/2013). A total of 104 NOD/SCID female mice (Animal Facility of Department of Clinical Immunology and Transplantology, Jagiellonian University Medical College, Krakow, Poland), 
which were 4-6-weeks old, were maintained under specific pathogen-free (SPF) conditions. Viable A549 cells in the number of $5 \times 10^{6}$ per mouse in $0.2-\mathrm{ml}$ Hank's medium (PChO IIET PAS) were injected subcutaneously (s.c.) into the right flank of the abdomen of all mice (day 0 ), and after the tumor volume reached $80 \mathrm{~mm}^{3}$ of the mean volume, the mice were randomly divided into 8 groups $(6$ mice were not included in further analysis as the tumors were too small for evaluation): control (12 mice), DTX (12 mice), SU (12 mice), 1,24(OH) ${ }_{2} \mathrm{D}_{3}$ (12 mice), $\mathrm{SU}+1,24(\mathrm{OH})_{2} \mathrm{D}_{3}\left(12\right.$ mice), $\mathrm{DTX}+1,24(\mathrm{OH})_{2} \mathrm{D}_{3}$ (12 mice), SU + DTX (13 mice) and SU + DTX + 1,24(OH $)_{2} \mathrm{D}_{3}$ (13 mice), receiving different combinations of the treatment agents so that the mean tumor volume in each group was comparable (day 17, D17). The compounds were administered from the following day as follows: i) DTX, once a week for 3 weeks intraperitoneally (i.p.) at a dose of $5 \mathrm{mg} / \mathrm{kg} /$ body weight [days (D)18, D24 and D31]; ii) SU, every day for 19 days by oral gavage at a dose of $40 \mathrm{mg} / \mathrm{kg} /$ body weight (from D19 to D36); iii) vitamin D analog $1,24(\mathrm{OH})_{2} \mathrm{D}_{3}$ thrice a week for 5 weeks s.c. at a dose of $1 \mu \mathrm{g} / \mathrm{kg} /$ body weight (D19, D21, D23, D26, D28, D30, D33, D35, D37, D40, D42, D44, D47 and D49).

The control mice received all three solvents used for the test compounds in the respected schedule, while the mice that received one or two compounds were also administered the solvent of the remaining compounds (e.g., mice receiving DTX also received citrate buffer (solvent of $\mathrm{SU}$ ) and $80 \%$ polyethylene glycol [solvent of $\left.1,24(\mathrm{OH})_{2} \mathrm{D}_{3}\right)$ ].

The growing tumors were measured thrice a week using digital caliper (Mitutoyo Corp., Kawasaki, Japan) during the experiment, and the body mass of animals was controlled on a precise scale (Mettler Toledo, Warsaw, Poland). Tumor volume was calculated using the formula $\left(a^{2} \mathrm{xb}\right) / 2$, where $\mathrm{a}=$ shorter tumor diameter $(\mathrm{mm})$ and $\mathrm{b}=$ longer tumor diameter $(\mathrm{mm})$. On the final day of the experiment (D51), when tumor volume exceeded 2,000 $\mathrm{mm}^{3}$, mice were anesthetized with 3-5\% (v/v) mixture of isoflurane (Aerrane isofluranum; Baxter, Canada) in synthetic air $(200 \mathrm{ml} / \mathrm{min})$ and blood was harvested from retro-orbital sinus separately from all mice in two tubes with or without anticoagulant EDTA (Kabe Labortechnik GmbH; Nümbrecht, Germany). The mice were then sacrificed by cervical dislocation and the tumors and selected organs (liver, spleen, kidneys, and heart) were harvested and weighed on a scale. The tumors were then frozen in liquid nitrogen and stored at $-80^{\circ} \mathrm{C}$ for subsequent analysis. Multiple tumors were not observed in our study.

Hematological and biochemical analysis of blood harvested from mice. Blood collected on EDTA anticoagulant was analyzed on a fully automated hematological analyzer Mythic C18 (Orphée S.A., Plan-les-Ouates, Switzerland) using Hematos v.1.1 software (Zelnet, Ostrow Wlkp., Poland) assessing 18 hematological and blood morphology parameters listed in Results. Blood was centrifuged for $15 \mathrm{~min}$ at 2,500 x g after the analysis, and the obtained plasma was transferred to new and clean tubes. Blood collected in tubes without anticoagulant was stored at room temperature for approximately $30 \mathrm{~min}$ to coagulate. The probes were then centrifuged at $1,500 \mathrm{x} \mathrm{g}$ for $10 \mathrm{~min}$, and serum obtained was transferred to new and clean tubes. Plasma and serum were then analyzed on a biochemical analyzer Cobas c111 (Roche Diagnostics International Ltd., Rotkreuz, Switzerland) to assess the levels of the following biochemical parameters: alanine aminotransferase (ALT), aspartate transaminase (AST), alkaline phosphatase (ALP), lactate dehydrogenase (LDH), bilirubin, calcium, cholesterol, creatinine, glucose, phosphates, urea and uric acid.

Statistical analysis. Statistical analysis was performed using STATISTICA version 7.1 software (StatSoft, Inc., Tulsa, OK, USA). First, using Levene's test, homogeneity of variance was tested and then parametric (one-way ANOVA) or non-parametric tests were used. Second, the Kruskal-Wallis ANOVA multiple comparison p-values (two-tailed) test and the Mann-Whitney $U$ test were used for tumor growth inhibition analysis. P-values $<0.05$ were considered to indicate statistically significant differences.

\section{Results}

Anti-proliferative activity of $G V, S U, C I S, D T X$ and $1,24(\mathrm{OH})_{2} \mathrm{D}_{3}$ or $1,25(\mathrm{OH})_{2} \mathrm{D}_{3}$, and their combinations. After the $\mathrm{IC}_{50}$ value of each agent alone was assessed (as described in the Materials and methods), we performed the analysis of the anti-proliferative activity of different combinations of a given TKI with a cytostatic drug (also termed CYT) and vitamin $\mathrm{D}$ compound to examine whether using two or three compounds at low concentrations is more effective in the inhibition of A549 lung cancer cell proliferation and if using vitamin D compounds additionally strengthens the cytotoxicity of the test agents against the A549 cells and HLMECs. GV or SU in combination with CIS exerted a more potent anti-proliferative effect against the A549 lung cancer cells compared to each agent alone. When a third compound, such as $1,24(\mathrm{OH})_{2} \mathrm{D}_{3}$ or $1,25(\mathrm{OH})_{2} \mathrm{D}_{3}$ was added, no additional effects were observed. GV or SU did not augment the antiproliferative activity of DTX alone. When $1,24(\mathrm{OH})_{2} \mathrm{D}_{3}$ or $1,25(\mathrm{OH})_{2} \mathrm{D}_{3}$ were also added, no additional activity was observed (Fig. 1).

The analysis of the nature of the interaction between the test compounds revealed synergism for the combination of SU or CIS with vitamin D compounds at the highest concentrations used, and for GV or SU combined with CIS and/or with vitamin D compounds ( $\mathrm{CI}<0.8)$. When DTX was used with GV or SU, additive effects or antagonism were observed, depending on the concentration used (Table I).

As DTX revealed a high anti-proliferative activity in all three test concentrations, the proliferation inhibition observed in combinations with GV or SU may have probably resulted mostly from DTX activity. Therefore, in the following experiment, we tested DTX at a 10 -fold lower concentration. The results revealed that the combination of DTX with GV or SU resulted in a greater inhibition of proliferation than $\mathrm{GV}, \mathrm{SU}$, or DTX alone (Fig. 2). CI analysis revealed that the interactions between the test compounds were still additive or antagonistic (Table II).

The analysis of the anti-proliferative activity of the test agents using the HLMECs revealed that $1,24(\mathrm{OH})_{2} \mathrm{D}_{3}$ and $1,25(\mathrm{OH})_{2} \mathrm{D}_{3}$ augmented the cytotoxic activity of $\mathrm{GV}, \mathrm{SU}, \mathrm{CIS}$, DTX and their combinations (Fig. 3). 

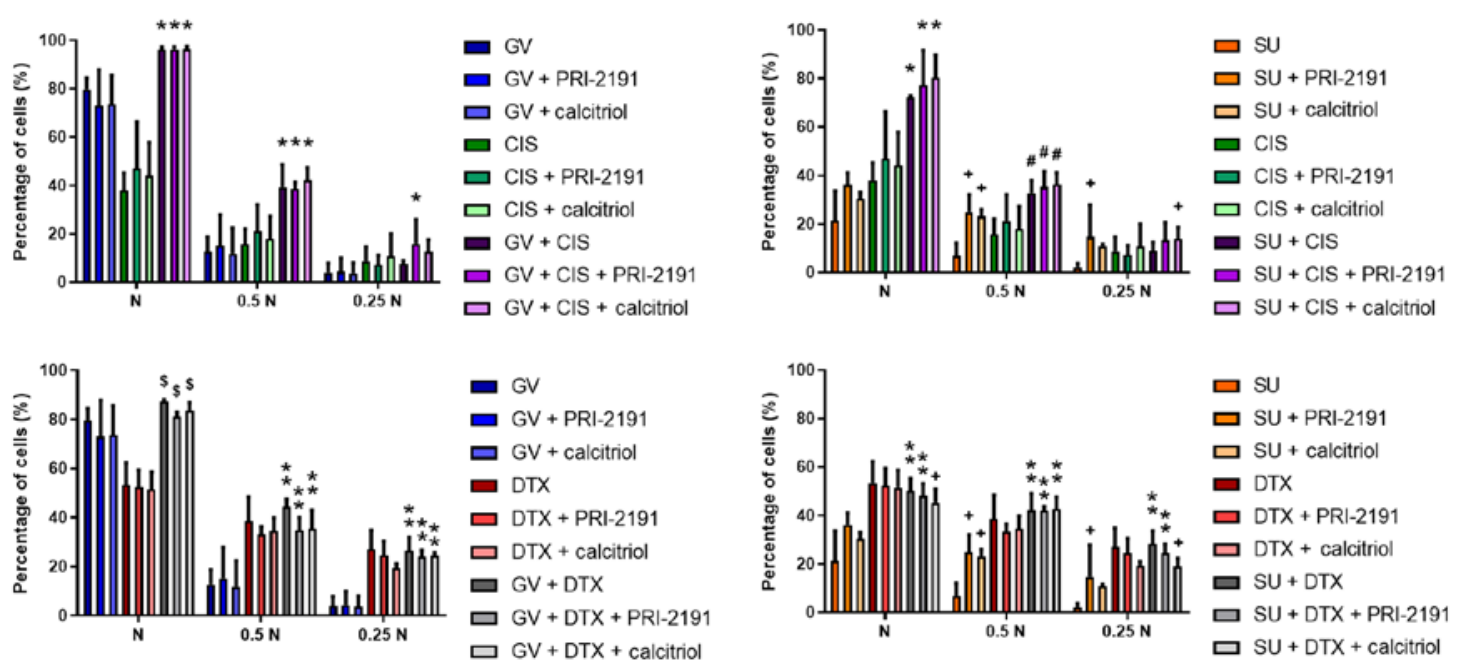

Figure 1. Antiproliferative activity of GV, SU, CIS, DTX, PRI-2191 and/or calcitriol against A549 lung cancer cells. A549 cells were exposed to combinations of the test compounds at different concentrations for $72 \mathrm{~h}: \mathrm{N}$, TKI and CYT were used at their respective $\mathrm{IC}_{50}$ concentrations; $0.5 \mathrm{~N}$, half of IC $50 ; 0.25 \mathrm{~N}$, a quarter of $\mathrm{IC}_{50}$; PRI-2191 and calcitriol were used at constant concentration of $100 \mathrm{nM}$. Bars represent the means $\pm \mathrm{SD} ;{ }^{*} \mathrm{p}<0.05$, compared with TKI, TKI + vit, CYT, CYT + vit; ${ }^{* *} \mathrm{p}<0.05$, compared with TKI and TKI + vit; ${ }^{+} \mathrm{p}<0.05$, compared with TKI; ${ }^{*} \mathrm{p}<0.05$, compared with TKI and CYT and CYT + vit; ${ }^{\$} \mathrm{p}<0.05$, compared with CYT and CYT + vit (one-way ANOVA, Fisher's test). GV, imatinib; SU, sunitinib; CIS, cisplatin; DTX, docetaxel; vit, vitamin D compound [PRI-2191, 1,24(OH) $\mathrm{D}_{3}$; Calcitriol, 1,25(OH $\left.)_{2} \mathrm{D}_{3}\right]$; TKI, tyrosine kinase inhibitor.
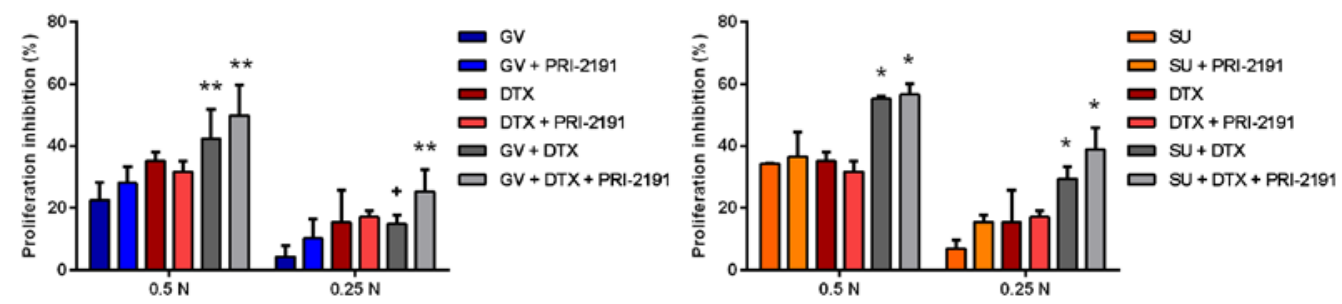

Figure 2. Anti-proliferative activity of GV and SU with DTX and/or with PRI-2191 against A549 lung cancer cells. DTX was used at concentration a 10-fold lower concentration than the calculated $\mathrm{IC}_{50}$ value. Bars represent the means $\pm \mathrm{SD}$; ${ }^{*} \mathrm{p}<0.05$, compared with TKI, TKI + vit, CYT, CYT + vit; ${ }^{* *} \mathrm{p}<0.05$, compared with TKI and TKI + vit (GV + DTX only compared to GV); ${ }^{+} \mathrm{p}<0.05$, compared with TKI (one-way ANOVA, Fisher's test). GV, imatinib; SU, sunitinib; DTX, docetaxel; vit, vitamin D compound [PRI-2191, 1,24(OH) $\left.\mathrm{D}_{3}\right]$; TKI, tyrosine kinase inhibitor.
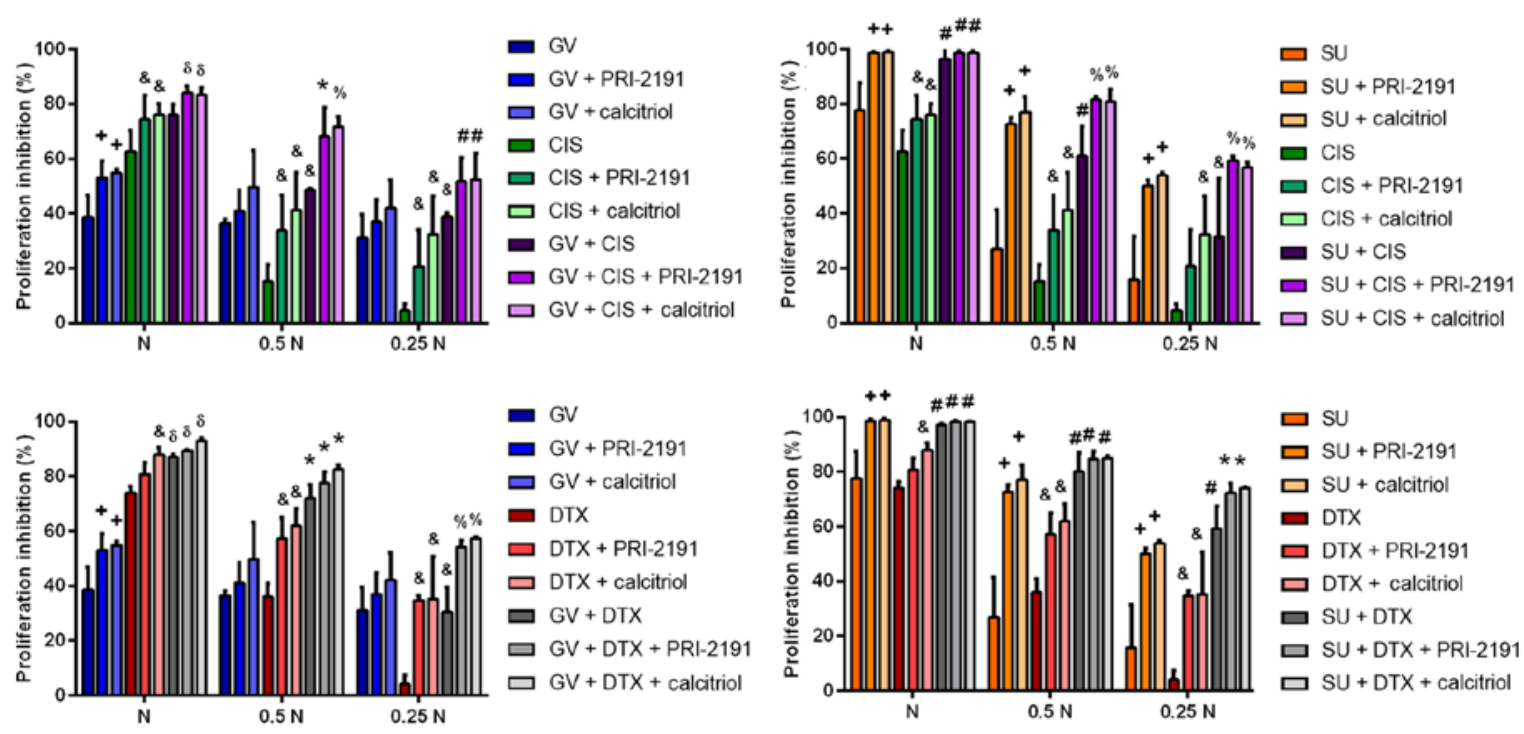

Figure 3. Anti-proliferative activity of GV, SU, CIS, DTX, PRI-2191 and/or calcitriol against human lung microvascular endothelial cells (HLMECs). HLMECs were exposed to combinations of the test compounds at different concentrations for $72 \mathrm{~h}: \mathrm{N}$, TKI and CYT were used at their respective IC 50 values; $0.5 \mathrm{~N}$, half of $\mathrm{IC}_{50} ; 0.25 \mathrm{~N}$, a quarter of $\mathrm{IC}_{50} ; \mathrm{PRI}-2191$ and calcitriol were used at a constant concentration of $100 \mathrm{nM}$. Bars represent the means $\pm \mathrm{SD}$; " $\mathrm{p}<0.05$, compared with TKI, TKI + vit, CYT, CYT + vit; ${ }^{+} \mathrm{p}<0.05$, compared with TKI; ${ }^{*} \mathrm{p}<0.05$, compared with TKI, CYT and CYT + vit; ${ }^{\delta} \mathrm{p}<0.05$, compared with TKI, TKI + vit and CYT; ${ }^{\$} \mathrm{p}<0.05$, compared with CYT and CYT + vit; ${ }^{\%} \mathrm{p}<0.05$, compared with TKI, CYT, CYT + vit and TKI + CYT (one-way ANOVA, Fisher's test). GV, imatinib; SU, sunitinib; CIS, cisplatin; DTX, docetaxel; vit, vitamin D compound [PRI-2191, 1,24(OH) $\left.{ }_{2} \mathrm{D}_{3} ; \mathrm{Calcitriol}, 1,25(\mathrm{OH})_{2} \mathrm{D}_{3}\right] ;$ TKI, tyrosine kinase inhibitor. 
Table I. Combination index (CI) for combinations of GV, SU, CIS, DTX with PRI-2191 or calcitriol for A549 lung cancer cells.

\begin{tabular}{|c|c|c|c|c|c|c|c|c|c|}
\hline \multirow[b]{2}{*}{ TKI/CYT } & \multicolumn{3}{|c|}{$\mathrm{N}^{\mathrm{b}}$} & \multicolumn{3}{|c|}{$0.5 \mathrm{~N}$} & \multicolumn{3}{|c|}{$0.25 \mathrm{~N}$} \\
\hline & $0^{c}$ & PRI-2191 & Calc & 0 & PRI-2191 & Calc & 0 & PRI-2191 & Calc \\
\hline GV & $--^{d}$ & 1.106 & 1.076 & - & 1.139 & 1.588 & - & 1.231 & 1.686 \\
\hline SU & - & 0.663 & 0.766 & - & 0.446 & 0.470 & - & 0.319 & 0.395 \\
\hline CIS & - & 0.712 & 0.776 & - & 0.867 & 1.018 & - & 1.074 & 0.799 \\
\hline DTX & - & 1.034 & 1.078 & - & 1.376 & 1.281 & - & 1.153 & 1.679 \\
\hline $\mathrm{GV}+\mathrm{CIS}$ & 0.570 & 0.564 & 0.559 & 1.229 & 1.247 & 1.165 & 1.771 & 1.134 & 1.308 \\
\hline $\mathrm{SU}+\mathrm{CIS}$ & 0.607 & 0.510 & 0.455 & 0.919 & 0.849 & 0.825 & 1.360 & 0.990 & 0.973 \\
\hline GV + DTX & 0.870 & 1.072 & 0.987 & 1.500 & 2.089 & 2.042 & 1.490 & 1.686 & 1.638 \\
\hline SU + DTX & 1.633 & 2.010 & 1.782 & 1.143 & 1.122 & 1.152 & 1.117 & 2.016 & 1.386 \\
\hline
\end{tabular}

CI was calculated using CalcuSyn Version 2.1 software based on proliferation inhibition, CI $<0.8$ synergism (bold font), CI 0.8-1.2 additive effect (normal font), CI >1.2 antagonism (italics); ${ }^{a}$ TKI, tyrosine kinase inhibitor and CYT, cytostatic drugs; ${ }^{b} \mathrm{~N}$ stands for $\mathrm{IC}_{50}$ of a given compound; ${ }^{c}$ without vitamin compound; ${ }^{\mathrm{d}} \mathrm{CI}$ is calculated for at least two compounds. GV, imatinib; SU, sunitinib; CIS, cisplatin; DTX, docetaxel; Calc, calcitriol.

Table II. Combination index (CI) for GV and SU with DTX and/or with PRI-2191 for A549 lung cancer cells.

\begin{tabular}{lcccccc}
\hline & \multicolumn{2}{c}{$0.5 \mathrm{~N}^{\mathrm{b}}$} & & \multicolumn{2}{c}{$0.25 \mathrm{~N}$} \\
\cline { 2 - 3 } \cline { 6 - 7 } TKI/CYT & & $0^{\mathrm{c}}$ & PRI-2191 & & 0 & PRI-2191 \\
\hline $\mathrm{GV}$ & $-^{\mathrm{d}}$ & 0.898 & & - & $\mathbf{0 . 7 1 1}$ \\
$\mathrm{SU}$ & - & 0.966 & & - & $\mathbf{0 . 7 2 6}$ \\
$\mathrm{DTX}$ & - & 1.102 & & - & 0.925 \\
$\mathrm{GV}+$ DTX & 1.527 & 1.311 & & 1.632 & 1.149 \\
$\mathrm{SU}+$ DTX & 1.329 & 1.296 & & 1.132 & 0.920 \\
\hline
\end{tabular}

CI was calculated using CalcuSyn Version 2.1 software based on proliferation inhibition, CI $<0.8$ synergism (bold font), CI 0.8-1.2 additive effect (normal font), CI $>1.2$ antagonism (italics); ${ }^{\mathrm{a}} \mathrm{TKI}$ tyrosine kinase inhibitor and CYT, cytostatic drugs; ${ }^{b} \mathrm{~N}$ stands for $\mathrm{IC}_{50}$ of a given compound; ${ }^{\mathrm{c}}$ without vitamin $\mathrm{D}$ compound; ${ }^{\mathrm{d}} \mathrm{CI}$ is calculated for at least two compounds; DTX was used at concentration 10 times lower than calculated $\mathrm{IC}_{50}$. GV, imatinib; SU, sunitinib; DTX, docetaxel.

Synergism was observed between the TKIs or the cytostatic drugs and $1,24(\mathrm{OH})_{2} \mathrm{D}_{3}$ or $1,25(\mathrm{OH})_{2} \mathrm{D}_{3}$. The interaction between $\mathrm{GV}$ or $\mathrm{SU}$ and cytostatic drugs was also synergistic in most cases, and the addition of $1,24(\mathrm{OH})_{2} \mathrm{D}_{3}$ or $1,25(\mathrm{OH})_{2} \mathrm{D}_{3}$ even augmented such an effect $(\mathrm{CI}<0.8)$. For those combinations for which an additive effect was observed, that is, $\mathrm{SU}+\mathrm{CIS}$ and SU + DTX, when vitamin D compounds were added, the mechanism of interaction shifted toward synergism (Table III).

Cell cycle and cell death analysis. In order to determine whether using the test drug combinations has an effect on specific phases of the cell cycle, that is, whether drug combinations arrest cells at the same or other phases as given agent alone, we performed cell cycle analysis. GV alone arrested the
A549 cells at the $\mathrm{G}_{0} / \mathrm{G}_{1}$ phase, decreasing the percentage of cells in the S phase compared to the control cells. SU, at the concentration used, did not affect the distribution of cells in cell the cycle phases, but when $1,24(\mathrm{OH})_{2} \mathrm{D}_{3}$ or $1,25(\mathrm{OH})_{2} \mathrm{D}_{3}$ was added with $\mathrm{SU}$, the percentage of cells in the $\mathrm{G}_{0} / \mathrm{G}_{1}$ phase increased compared to the control cells. CIS decreased the percentage of cells in the $G_{0} / G_{1}$ phase and increased that of cells in the $\mathrm{G}_{2} / \mathrm{M}$ phase compared to the control cells. The addition of vitamin D compounds to CIS resulted in a decrease in the percentage of cells in the $\mathrm{S}$ phase with a simultaneous increase in the percentage of cells in the $G_{2} / M$ phase compared to CIS alone. DTX also decreased the percentage of cells in the $\mathrm{G}_{0} / \mathrm{G}_{1}$ phase, but increased that of cells in the $S$ phase compared to the control cells. When $1,24(\mathrm{OH})_{2} \mathrm{D}_{3}$ or $1,25(\mathrm{OH})_{2} \mathrm{D}_{3}$ was added to DTX, no additional effects were observed. In the case of treatment of the A549 cells with GV or SU together with CIS, the percentage of cells in the $\mathrm{G}_{0} / \mathrm{G}_{1}$ and $S$ phase decreased, while that of the cells in the $G_{2} / M$ phase increased compared to the controls, and to treatment with CIS, GV and $\mathrm{SU}$ alone. $1,24(\mathrm{OH})_{2} \mathrm{D}_{3}$ or $1,25(\mathrm{OH})_{2} \mathrm{D}_{3}$ added to these combinations augmented the observed effects. GV with DTX increased the percentage of cells in the $\mathrm{G}_{0} / \mathrm{G}_{1}$ phase compared to DTX, and the percentage of cells in S phase compared to GV alone, while it decreased the percentage of cells in the $\mathrm{G}_{2} / \mathrm{M}$ phase compared with the control and the agents used alone. Treatment of the A549 cells with SU together with DTX resulted in a decrease in the percentage of cells in the $\mathrm{G}_{0} / \mathrm{G}_{1}$ phase, and in an increase in the percentage of cells in the $\mathrm{G}_{2} / \mathrm{M}$ phase compared to the controls and the compounds used alone, and also resulted in a decrease in the percentage of $\mathrm{S}$ phase cells compared to DTX alone. By introducing $1,24(\mathrm{OH})_{2} \mathrm{D}_{3}$ or $1,25(\mathrm{OH})_{2} \mathrm{D}_{3}$ to these combinations ( $\mathrm{p}<0.05$, one-way ANOVA, Fisher's test) (Fig. 4), no additional effects were observed.

$1,24(\mathrm{OH})_{2} \mathrm{D}_{3}$ or $1,25(\mathrm{OH})_{2} \mathrm{D}_{3}$ or $\mathrm{SU}$ treatment of the HLMECs resulted in a slight increase in the percentage of cells in the $G_{0} / G_{1}$ phase. When SU was used together with one of the vitamin $\mathrm{D}$ analogs, the increase in the cell percentage 
Table III. Combination index (CI) for combinations of GV, SU, CIS, DTX with PRI-2191 or calcitriol for human lung microvascular endothelial cells (HLMECs).

\begin{tabular}{|c|c|c|c|c|c|c|c|c|c|}
\hline \multirow[b]{2}{*}{$\mathrm{TKI} / \mathrm{CYT}^{\mathrm{a}}$} & \multicolumn{3}{|c|}{$\mathrm{N}^{\mathrm{b}}$} & \multicolumn{3}{|c|}{$0.5 \mathrm{~N}$} & \multicolumn{3}{|c|}{$0.25 \mathrm{~N}$} \\
\hline & $0^{\mathrm{c}}$ & PRI-2191 & Calc & 0 & PRI-2191 & Calc & 0 & PRI-2191 & Calc \\
\hline GV & $-{ }^{\mathrm{d}}$ & 0.102 & 0.152 & - & 0.378 & 0.187 & - & 0.377 & 0.300 \\
\hline SU & - & 0.367 & 0.324 & - & 0.637 & 0.634 & - & 0.494 & 0.545 \\
\hline CIS & - & 0.758 & 0.755 & - & 0.755 & 0.814 & - & 0.618 & 0.637 \\
\hline DTX & - & 0.926 & 0.782 & - & 0.677 & 0.686 & - & 0.465 & 0.669 \\
\hline $\mathrm{GV}+\mathrm{CIS}$ & 0.735 & 0.600 & 0.624 & 0.693 & 0.430 & 0.431 & 0.603 & 0.312 & 0.391 \\
\hline $\mathrm{SU}+\mathrm{CIS}$ & 0.858 & 0.584 & 0.569 & 1.315 & 0.871 & 0.903 & 1.062 & 0.675 & 0.772 \\
\hline GV + DTX & 0.792 & 0.734 & 0.638 & 0.546 & 0.494 & 0.459 & 1.711 & 0.372 & 0.418 \\
\hline SU + DTX & 0.945 & 0.803 & 0.795 & 1.040 & 0.927 & 0.933 & 0.755 & 0.609 & 0.615 \\
\hline
\end{tabular}

CI was calculated using CalcuSyn Version 2.1 software based on proliferation inhibition, CI $<0.8$ synergism (bold font), CI 0.8-1.2 additive effect (normal font), CI >1.2 antagonism (italics); ${ }^{a} \mathrm{TKI}$ tyrosine kinase inhibitor and CYT, cytostatic drugs; ${ }^{\mathrm{b}} \mathrm{N}$ stands for $\mathrm{IC}_{50}$ of a given compound; ' ${ }^{c}$ without vitamin D compound; ${ }^{\mathrm{d}} \mathrm{CI}$ is calculated for at least two compounds. GV, imatinib; SU, sunitinib; CIS, cisplatin; DTX, docetaxel; Calc, calcitriol.
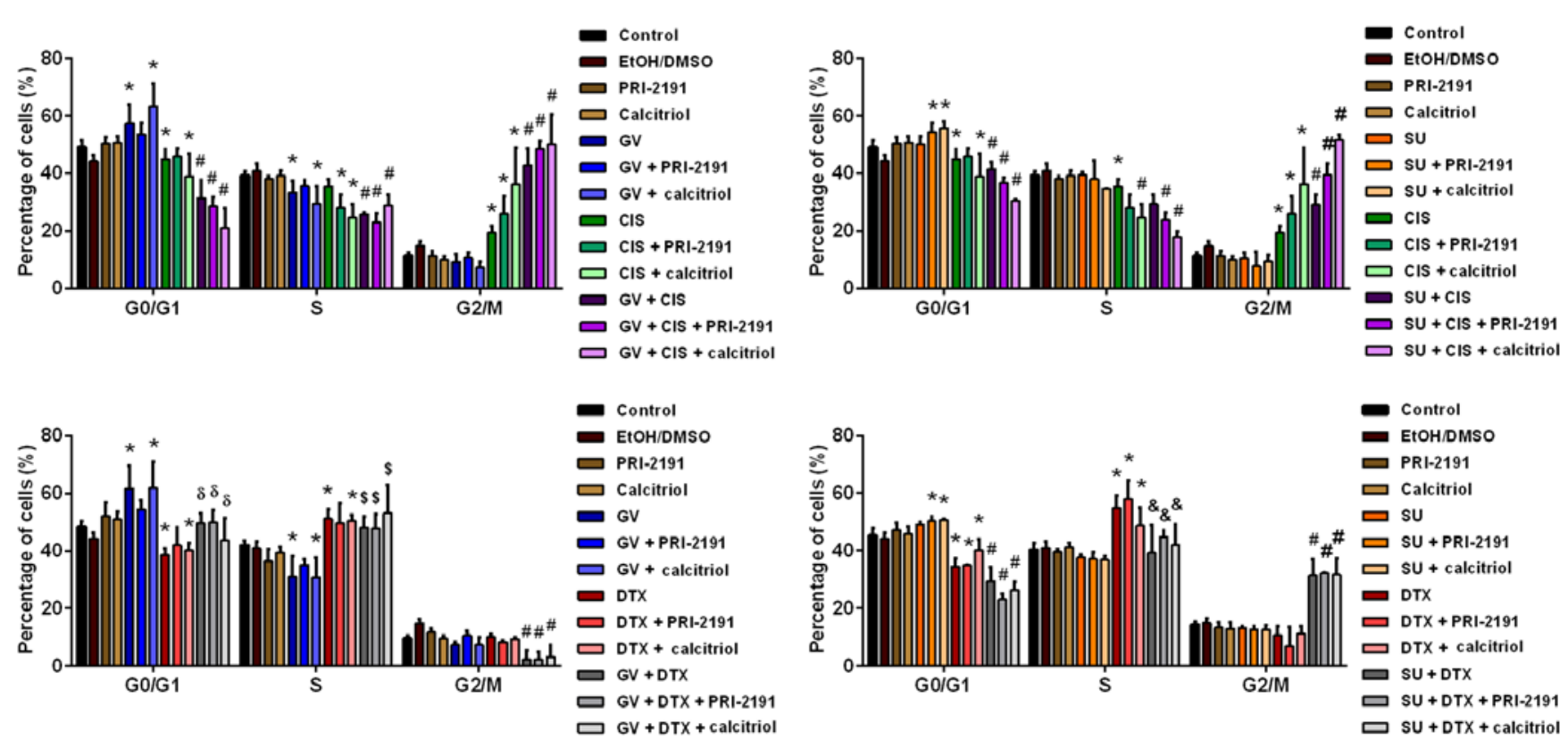

Figure 4. Cell cycle analysis of A549 lung cancer cells after $72 \mathrm{~h}$ of incubation with GV, SU, CIS, DTX and/or PRI-2191 or calcitriol. Bars represent the means \pm SD. ${ }^{*} \mathrm{p}<0.05$ compared with control; ${ }^{\sharp} \mathrm{p}<0.05$, compared with control and CIS or DTX and GV or SU; ${ }^{\$} \mathrm{p}<0.05$, compared with GV and DTX; ${ }^{\$} \mathrm{p}<0.05$, compared with GV; ${ }^{\&} \mathrm{p}<0.05$, compared with DTX (one-way ANOVA, Fisher's test). GV, imatinib; SU, sunitinib; CIS, cisplatin; DTX, docetaxel; PRI-2191, $1,24(\mathrm{OH})_{2} \mathrm{D}_{3} ;$ Calcitriol, $1,25(\mathrm{OH})_{2} \mathrm{D}_{3}$.

in the $\mathrm{G}_{0} / \mathrm{G}_{1}$ phase was statistically significant compared to the controls or to treatment with SU and vitamin D compounds alone. GV had no effect on the cell cycle of the HLMECs. CIS treatment increased the percentage of cells in the $S$ phase and decreased that of cells in the $\mathrm{G}_{0} / \mathrm{G}_{1}$ phase compared with the controls. The increase in the percentage of cells in the $\mathrm{G}_{2} / \mathrm{M}$ phase was observed when CIS was applied together with $1,24(\mathrm{OH})_{2} \mathrm{D}_{3}$ or $1,25(\mathrm{OH})_{2} \mathrm{D}_{3}$ (Fig. 5 ).

Treatment of the HLMECs with the combination of SU and CIS resulted in a lower percentage of cells in the $G_{0} / G_{1}$ phase and in an increase in the percentage of cells in the $\mathrm{G}_{2} / \mathrm{M}$ phase compared to the controls, or to treatment with SU and CIS alone. The percentage of cells in $\mathrm{G}_{2} / \mathrm{M}$ phase was even higher when $1,24(\mathrm{OH})_{2} \mathrm{D}_{3}$ or $1,25(\mathrm{OH})_{2} \mathrm{D}_{3}$ was added. In the case of $\mathrm{GV}$ treatment together with CIS, the percentage of cells in the $G_{0} / G_{1}$ phase decreased and the percentage of cells in the $S$ phase increased compared to the controls and to treatment with GV alone. An increase in the percentage of cells in the $\mathrm{G}_{2} / \mathrm{M}$ phase was observed when the HLMECs were exposed to GV, CIS and 1,24(OH) $)_{2} \mathrm{D}_{3}$ (Fig. 5). 

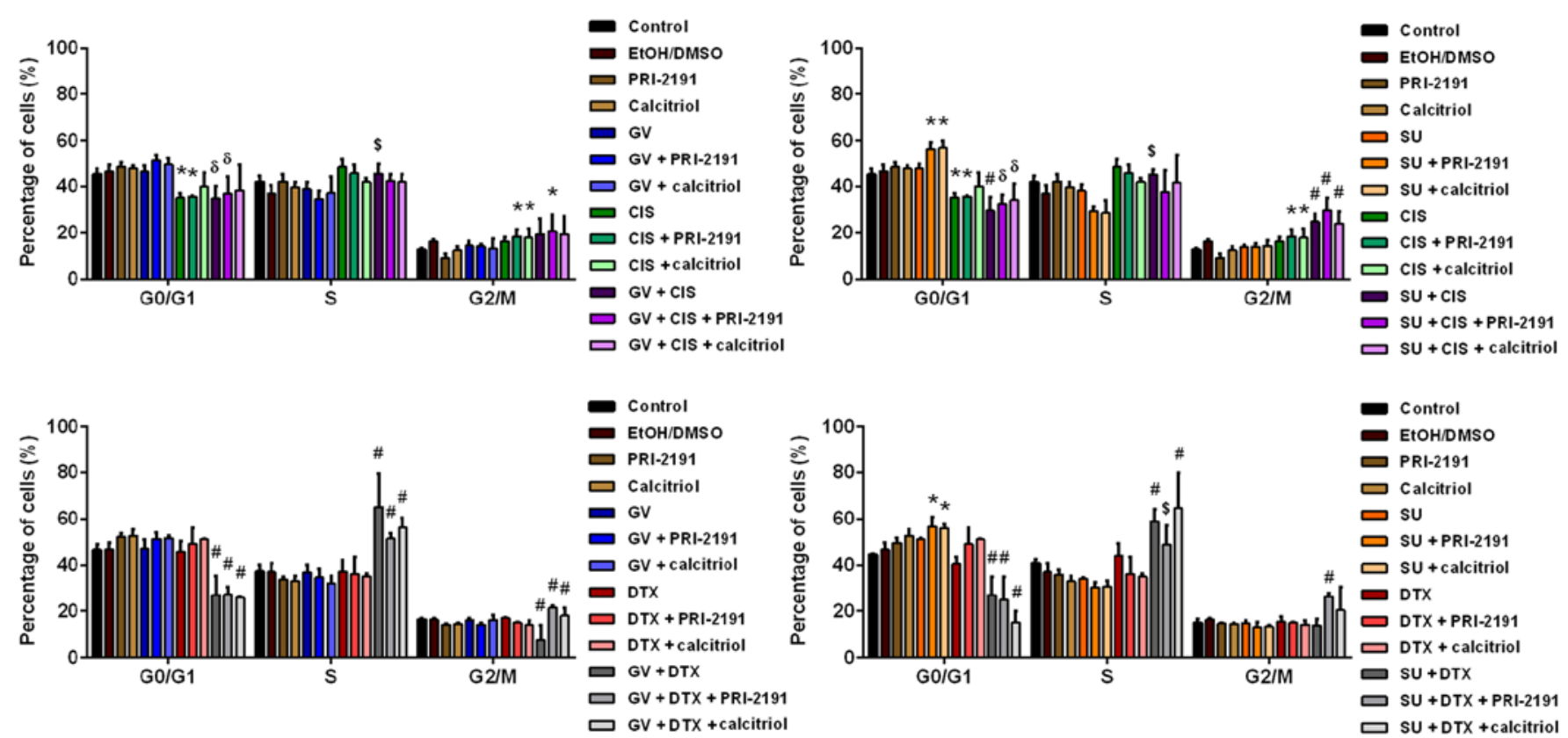

Figure 5. Cell cycle analysis of human lung microvascular endothelial cells (HLMECs) after $72 \mathrm{~h}$ of incubation with GV, SU, CIS, DTX and/or PRI-2191 or calcitriol. Bars represent the means $\pm \mathrm{SD}$. " $\mathrm{p}<0.05$, compared with control; ${ }^{*} \mathrm{p}<0.05$, compared with control and CIS or DTX and GV or SU; ${ }^{\delta} \mathrm{p}<0.05$, compared with control and GV or SU; ${ }^{\$}$ p $<0.05$, compared with GV or SU (one-way ANOVA, Fisher's test). GV, imatinib; SU, sunitinib; CIS, cisplatin; DTX, docetaxel; PRI-2191, 1,24(OH $)_{2} \mathrm{D}_{3}$; Calcitriol, 1,25(OH $)_{2} \mathrm{D}_{3}$.

GV in combination with DTX resulted in a decrease in the percentage of cells in the $G_{0} / G_{1}$ and $G_{2} / M$ phases, and in an increase in the percentage of cells in the $S$ phase compared to the controls, or to treatment with GV and DTX alone. The percentage of cells in the $\mathrm{G}_{2} / \mathrm{M}$ phase increased compared with the combination of GV and DTX when the HLMECs were exposed to GV and DTX in combination with $1,24(\mathrm{OH})_{2} \mathrm{D}_{3}$ or $1,25(\mathrm{OH})_{2} \mathrm{D}_{3}$. SU with DTX decreased the percentage of cells in the $G_{0} / G_{1}$ phase and increased that of cells in the $\mathrm{S}$ phase compared to the controls, or to treatment with $\mathrm{SU}$ and DTX alone, while the addition of $1,24(\mathrm{OH})_{2} \mathrm{D}_{3}$ to $\mathrm{SU}$ and DTX resulted in a small decrease in the percentage of cells in the S phase compared to SU in combination with DTX, and in an increase in the percentage of cells in the $\mathrm{G}_{2} / \mathrm{M}$ phase compared to the controls, SU alone, DTX alone, and SU with DTX (p $<0.05$, one-way ANOVA, Fisher's test) (Fig. 5).

Cell death analysis using propidium iodide staining and flow cytometric analysis revealed that treatment of the A549 cells and HLMECs with a combination of TKIs (GV or SU) with cytostatic drugs (CIS or DTX) resulted in an increase in the percentage of cells in the subG1 population compared to the controls, or to TKIs and CYT used alone. The test vitamin D compounds, such as $1,24(\mathrm{OH})_{2} \mathrm{D}_{3}$ and $1,25(\mathrm{OH})_{2} \mathrm{D}_{3}$ did not further augment the effects of TKIs and CYT in the case of A549 cells, but did increase the percentage of HLMECs in the subG1 population. The highest induction of cell death was observed upon treatment with SU in combination with CIS or DTX and $1,24(\mathrm{OH})_{2} \mathrm{D}_{3}$ or $1,25(\mathrm{OH})_{2} \mathrm{D}_{3}(\mathrm{p}<0.05$, one-way ANOVA, Fisher's test) (Table IV).

Caspase-3 activity in A549 lung cancer cells and HLMECs. We measured caspase- 3 activity to determine whether the observed increase in the percentage of dead cells was a result of apoptosis. Compared to the untreated cells, treatment of the A549 cells with GV resulted in a significant increase in caspase- 3 activity. The addition of the vitamin D compounds to GV decreased caspase-3 activity induced by GV alone. SU slightly decreased the activity of protease compared to its basal level observed in the untreated cells, and in the cells treated with combinations of SU with $1,24(\mathrm{OH})_{2} \mathrm{D}_{3}$ or $1,25(\mathrm{OH})_{2} \mathrm{D}_{3}$, the activity of caspase-3 was even lower. GV in combination with CIS caused a significantly higher enzyme activity compared with the untreated cells and cells incubated with GV or CIS alone. However, when $1,24(\mathrm{OH})_{2} \mathrm{D}_{3}$ or $1,25(\mathrm{OH})_{2} \mathrm{D}_{3}$ was added to the combination of GV with CIS, a decreased activity of caspase- 3 was observed. The increase in caspase- 3 activity was also observed for SU in combination with CIS, but only when compared to SU alone (Fig. 6).

Upon treatment with DTX, a significant increase in caspase-3 activity was also observed. A further increase in enzyme activity was observed when DTX was used together with GV. However, the addition of $1,24(\mathrm{OH})_{2} \mathrm{D}_{3}$ or $1,25(\mathrm{OH})_{2} \mathrm{D}_{3}$ to GV with DTX resulted in a decrease in protease activity compared with a previously achieved increase using the double combination of GV and DTX. A significant decrease in caspase-3 activity was observed using SU in combination with DTX compared to DTX alone ( $\mathrm{p}<0.05$, one-way ANOVA, Fisher's test) (Fig. 6).

Caspase-3 activity in the HLMECs was not affected by GV and SU alone. A significant increase in enzyme activity was noted upon treatment of the HLMECs with CIS or DTX together with $1,24(\mathrm{OH})_{2} \mathrm{D}_{3}$ or $1,25(\mathrm{OH})_{2} \mathrm{D}_{3}$. No additional changes in caspase-3 activity were observed when GV was added to CIS or DTX in combination with $1,24(\mathrm{OH})_{2} \mathrm{D}_{3}$ or $1,25(\mathrm{OH})_{2} \mathrm{D}_{3}$. The highest increase in caspase- 3 activity in the HLMECs was observed following incubation with $\mathrm{SU}$ in combination with CIS or DTX and $1,24(\mathrm{OH})_{2} \mathrm{D}_{3}$ or $1,25(\mathrm{OH})_{2} \mathrm{D}_{3}$, which was statistically significant compared with the untreated and 
Table IV. The percentage of A549 and human lung microvascular endothelial cells (HLMECs) in the subG1 population (cell death) after $72 \mathrm{~h}$ of incubation with TKI, CYT and vitamin D compounds.

\begin{tabular}{lccccccc}
\hline & \multicolumn{3}{c}{ A549 } & & \multicolumn{3}{c}{ HLMEC } \\
\cline { 2 - 4 } \cline { 6 - 7 } Group & - & PRI-2191 & Calcitriol & & - & PRI-2191 & Calcitriol \\
\hline Control & $5.7 \pm 2.9$ & $6.3 \pm 5.6$ & $6.5 \pm 2.8$ & & $6.7 \pm 2.4$ & $15.2 \pm 5.3^{\mathrm{a}}$ & $14.9 \pm 4.2^{\mathrm{a}}$ \\
GV & $13.4 \pm 4.5^{\mathrm{a}}$ & $12.3 \pm 4.3$ & $13.9 \pm 2.8$ & & $8.9 \pm 2.8$ & $16.2 \pm 7.7^{\mathrm{a}}$ & $18.1 \pm 7.6^{\mathrm{a}}$ \\
SU & $9.5 \pm 6.5$ & $11.0 \pm 8.2$ & $7.1 \pm 3.1$ & & $8.6 \pm 3.5$ & $28.0 \pm 6.0^{\mathrm{a}}$ & $19.9 \pm 11.1^{\mathrm{a}}$ \\
DTX & $17.9 \pm 3.5^{\mathrm{a}}$ & $19.7 \pm 5.3^{\mathrm{a}}$ & $18.3 \pm 3.7^{\mathrm{a}}$ & & $9.0 \pm 3.1$ & $18.3 \pm 3.2^{\mathrm{b}}$ & $15.2 \pm 2.9^{\mathrm{a}}$ \\
GV + DTX & $31.7 \pm 5.7^{\mathrm{b}}$ & $35.1 \pm 4.1^{\mathrm{b}}$ & $38.5 \pm 7.3^{\mathrm{b}}$ & & $24.8 \pm 6.0^{\mathrm{b}}$ & $36.5 \pm 6.2^{\mathrm{d}}$ & $34.6 \pm 4.0^{\mathrm{d}}$ \\
SU + DTX & $27.9 \pm 5.0^{\mathrm{b}}$ & $28.4 \pm 7.9^{\mathrm{b}}$ & $29.4 \pm 4.7^{\mathrm{b}}$ & & $29.7 \pm 5.6^{\mathrm{b}}$ & $55.4 \pm 7.3^{\mathrm{d}}$ & $50.9 \pm 7.5^{\mathrm{d}}$ \\
CIS & $25.0 \pm 6.2^{\mathrm{a}}$ & $27.8 \pm 4.6^{\mathrm{a}}$ & $20.4 \pm 9.1^{\mathrm{a}}$ & & $15.8 \pm 9.8$ & $24.4 \pm 13.6^{\mathrm{a}}$ & $26.3 \pm 12.2^{\mathrm{a}}$ \\
GV + CIS & $36.3 \pm 3.6^{\mathrm{c}}$ & $39.9 \pm 5.0^{\mathrm{b}}$ & $42.4 \pm 16.1^{\mathrm{b}}$ & & $20.0 \pm 15.0$ & $30.3 \pm 16.7^{\mathrm{c}}$ & $31.0 \pm 25.4^{\mathrm{c}}$ \\
SU + CIS & $32.0 \pm 7.3^{\mathrm{c}}$ & $21.0 \pm 2.9^{\mathrm{a}}$ & $38.2 \pm 22.8^{\mathrm{c}}$ & & $32.9 \pm 18.0^{\mathrm{b}}$ & $64.7 \pm 8.1^{\mathrm{d}}$ & $52.3 \pm 14.8^{\mathrm{d}}$ \\
\hline
\end{tabular}

${ }^{\mathrm{a} C}$ Compared with control; ${ }^{\mathrm{b}}$ compared with control, TKI, and CYT; ${ }^{\mathrm{c}}$ compared with control and TKI; ${ }^{\mathrm{d}}$ compared with control, TKI, CYT, and TKI + CYT ( $p<0.05$, one-way ANOVA, Fisher's test). GV, imatinib; SU, sunitinib; CIS, cisplatin; DTX, docetaxel; TKI, tyrosine kinase inhibitor; CYT, cytostatic drug.
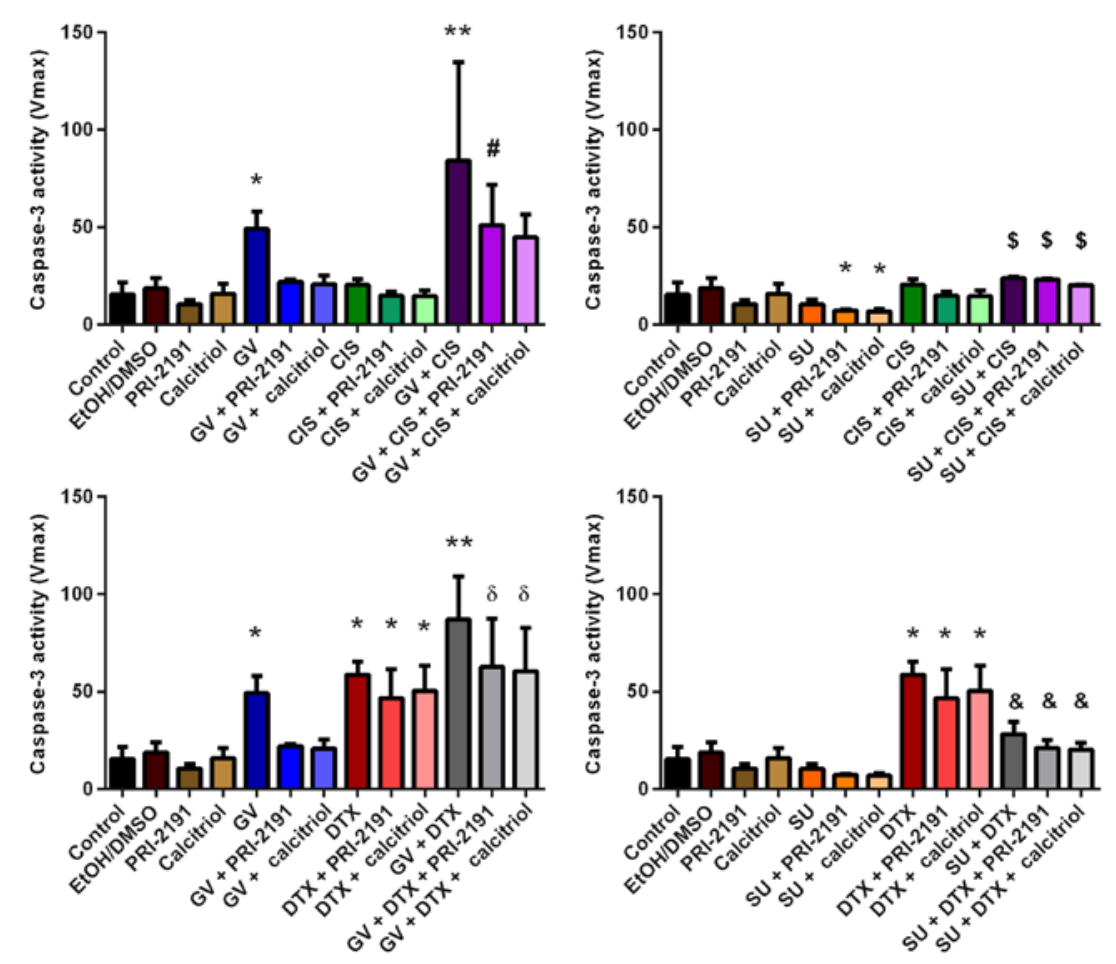

Figure 6. Caspase-3 activity in A549 cells after $72 \mathrm{~h}$ of incubation with the tested combinations of TKIs, CYT and vitamin D compounds. Bars represent the means $\pm \mathrm{SD}$. " $\mathrm{p}<0.05$, compared with control; ${ }^{* *} \mathrm{p}<0.05$, compared with control, TKI, and CYT; ${ }^{*} \mathrm{p}<0.05$, compared with control and CYT + vit; ${ }^{\circ} \mathrm{p}<0.05$, compared with control and TKI + vit; ${ }^{\$} \mathrm{p}<0.05$, compared with TKI; ${ }^{\star} \mathrm{p}<0.05$, compared with TKI and CYT (one-way ANOVA, Fisher's test). GV, imatinib; SU, sunitinib; CIS, cisplatin; DTX, docetaxel; TKI, tyrosine kinase inhibitor; CYT, cytostatic drug; vit, vitamin D compound [PRI-2191, 1,24(OH) ${ }_{2} \mathrm{D}_{3}$; Calcitriol, $\left.1,25(\mathrm{OH})_{2} \mathrm{D}_{3}\right]$.

SU- or CIS- or DTX-treated cells ( $\mathrm{p}<0.05$, one-way ANOVA, Fisher's test) (Fig. 7).

Sunitinib and cisplatin decrease VEGF-A secretion by A549 lung cancer cells. Using ELISA, the effects of the test compounds on VEGF-A secretion by A549 lung cancer cells were analyzed in conditioned medium. The A549 cells exposed to $\mathrm{SU}$ alone or in combination with $1,24(\mathrm{OH})_{2} \mathrm{D}_{3}$ or $1,25(\mathrm{OH})_{2} \mathrm{D}_{3}$ secreted significantly less VEGF-A into the conditioned medium compared to the untreated cells. In addition, treatment of the A549 cells with CIS alone or in combination with vitamin D compounds resulted in a decrease in VEGF-A levels compared with the untreated cells. The addition of GV to CIS did not augment the effect 

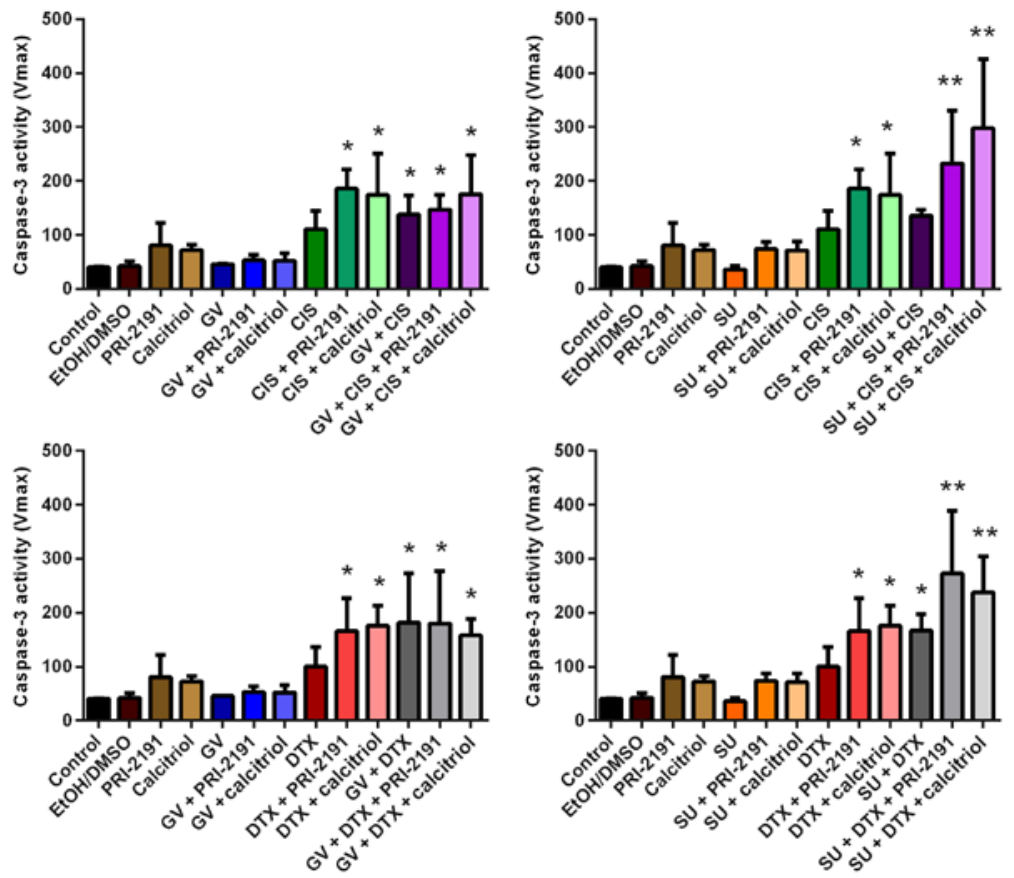

Figure 7. Caspase-3 activity in human lung microvascular endothelial cells (HLMECs) after $72 \mathrm{~h}$ of incubation with the tested combinations of TKIs, CYT and vitamin D compounds. Bars represent the means \pm SD. ${ }^{*} \mathrm{p}<0.05$, compared with control and TKI; ${ }^{* *} \mathrm{p}<0.05$, compared with control, TKI and CYT (one-way ANOVA, Fisher's test). GV, imatinib; SU, sunitinib; CIS, cisplatin; DTX, docetaxel; TKI, tyrosine kinase inhibitor; CYT, cytostatic drug; PRI-2191, $1,24(\mathrm{OH})_{2} \mathrm{D}_{3} ;$ Calcitriol, $1,25(\mathrm{OH})_{2} \mathrm{D}_{3}$.
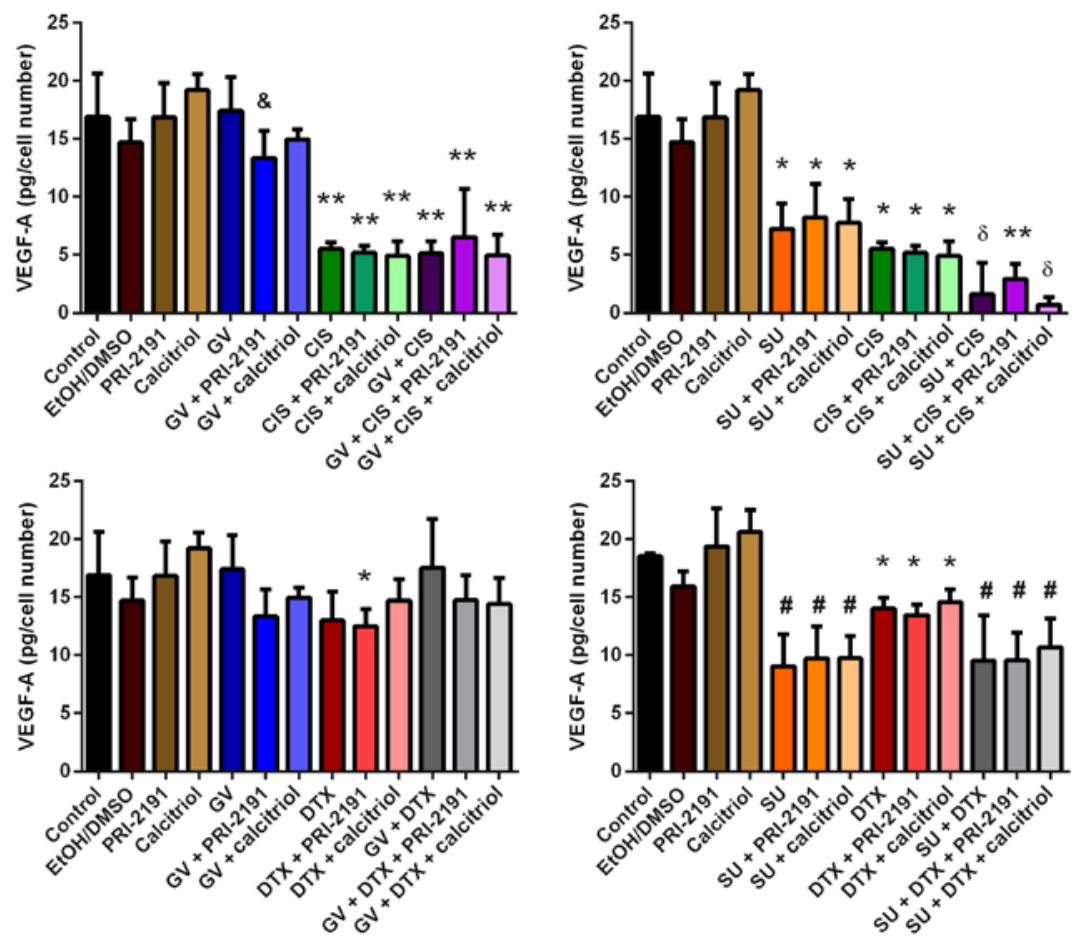

Figure 8. VEGF-A secretion by A549 lung cancer cells in vitro following treatment with GV, SU, CIS, DTX, PRI-2191 and/or calcitriol. Bars represent the means \pm SD. VEGF-A level was normalized to the number of cells assessed indirectly using sulforhodamine B (SRB) assay. "p $<0.05$, compared with control; ${ }^{* *} \mathrm{p}<0.05$, compared with control and TKI; ${ }^{\mathrm{p}} \mathrm{p}<0.05$, compared with TKI; ${ }^{*} \mathrm{p}<0.05$, compared with control and CYT; ${ }^{8} \mathrm{p}<0.05$, compared with control, TKI, and CYT (one-way ANOVA, Fisher's test). GV, imatinib; SU, sunitinib; CIS, cisplatin; DTX, docetaxel; TKI, tyrosine kinase inhibitor; CYT, cytostatic drug; PRI-2191, 1,24(OH $)_{2} \mathrm{D}_{3}$; Calcitriol, $1,25(\mathrm{OH})_{2} \mathrm{D}_{3}$.

achieved by CIS alone. However, the most prominent inhibition of VEGF-A was observed when the A549 cells were exposed to SU and CIS, which was statistically significant compared with the untreated and SU- or CIS-treated cells.
$1,24(\mathrm{OH})_{2} \mathrm{D}_{3}$ or $1,25(\mathrm{OH})_{2} \mathrm{D}_{3}$ did not further augment such an effect. DTX in combination with GV or SU had no effect on VEGF-A production $(\mathrm{p}<0.05$, one-way ANOVA, Fisher's test) (Fig. 8). 

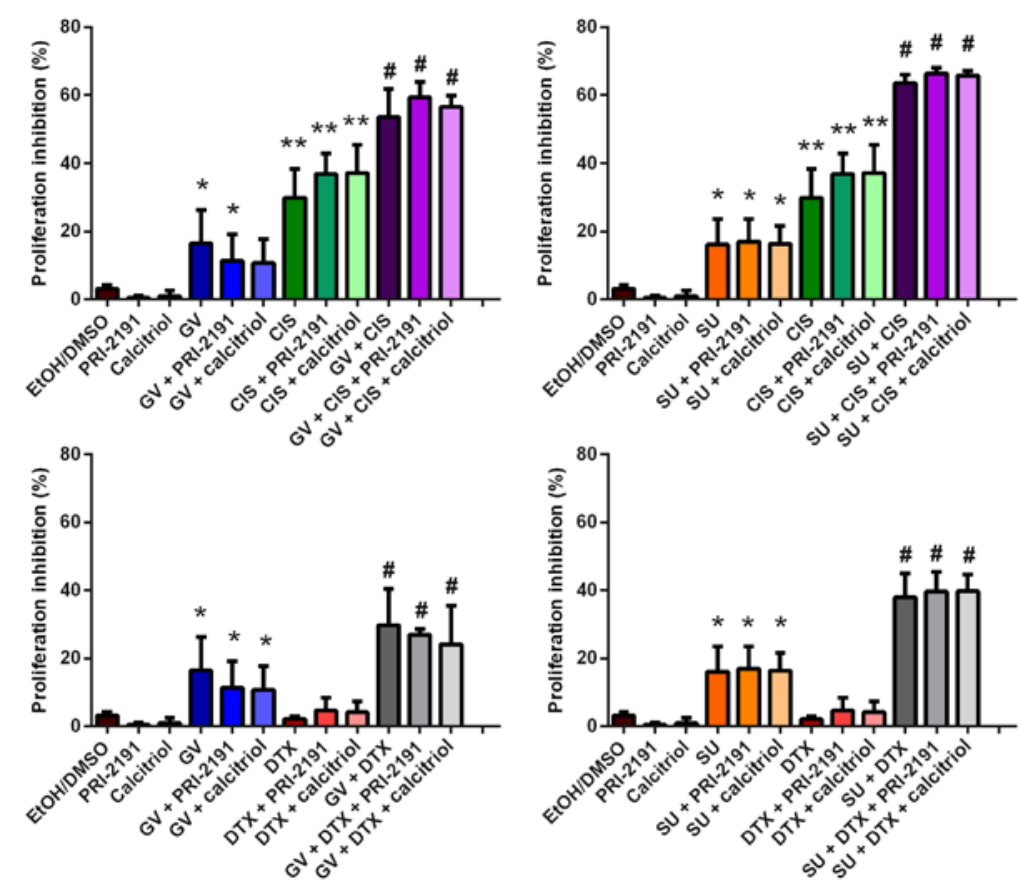

Figure 9. Inhibition of the proliferation of A549 cells after $72 \mathrm{~h}$ of incubation with GV, SU, CIS, DTX, PRI-2191 and/or calcitriol, followed by $48 \mathrm{~h}$ of culture in medium without FBS. Bars represent the means $\pm \mathrm{SD} .{ }^{*} \mathrm{p}<0.05$, compared with EtOH/DMSO and vitamin D compounds; ${ }^{* *} \mathrm{p}<0.05$, compared with EtOH/DMSO, vitamin D compounds, and TKI; ${ }^{*} \mathrm{p}<0.05$, compared with EtOH/DMSO, vitamin D compounds, TKI, and CYT (one-way ANOVA, Fisher's test). GV, imatinib; $\mathrm{SU}$, sunitinib; CIS, cisplatin; DTX, docetaxel; TKI, tyrosine kinase inhibitor; CYT, cytostatic drug; PRI-2191, 1,24(OH) ${ }_{2} \mathrm{D}_{3} ; \mathrm{Calcitriol,} 1,25(\mathrm{OH})_{2} \mathrm{D}_{3}$

The results of the inhibition of the proliferation of the A549 cells resulting from $72 \mathrm{~h}$ of incubation with $\mathrm{GV}, \mathrm{SU}$, CIS, DTX, $1,24(\mathrm{OH})_{2} \mathrm{D}_{3}$ and/or $1,25(\mathrm{OH})_{2} \mathrm{D}_{3}$ and their combinations, followed by $48 \mathrm{~h}$ of culture in medium without FBS are presented in Fig. 9. After the conditioned media were collected for ELISA, SRB assay was performed on the A549 cells present in 96-well plates.

Effects of GV, SU, CIS, DTX, 1,24(OH $)_{2} D_{3}$ and $1,25(\mathrm{OH})_{2} D_{3}$ on p53 and p21 expression in A549 cells. One of the functions of the p53 pathway is the regulation of the process of angiogenesis, for example, the downregulation of the expression of the pro-angiogenic factor, VEGF-A (25). In this study, we examined the effects of the test compound combinations on the protein expression of $\mathrm{p} 53$ and its target protein, $\mathrm{p} 21$, in A549 cells, in order to determine whether the changes in VEGF-A levels upon treatment with the test agents are the result of the upregulation of the p53 pathway. Densitometric analysis revealed that $72 \mathrm{~h}$ of incubation of the A549 cells with GV, SU, or vitamin D compounds did not affect p53 and p21 expression, while CIS and DTX induced p53 and p21 protein expression. The addition of GV or SU to CIS did not augment the level of p53 compared to treatment with CIS alone (Fig. 10). It was observed that the level of p53 protein expression was higher than that observed for DTX alone or DTX with $1,24(\mathrm{OH})_{2} \mathrm{D}_{3}$ or $1,25(\mathrm{OH})_{2} \mathrm{D}_{3}$ following treatment of the A549 with DTX in combination with GV or with SU and/or with $1,24(\mathrm{OH})_{2} \mathrm{D}_{3}$ or $1,25(\mathrm{OH})_{2} \mathrm{D}_{3}$ (Fig. 10A). Together with the induction of p53 expression by the test compounds, the upregulation of p21 expression was observed (Fig. 10B) $(\mathrm{p}<0.05$, one-way ANOVA, Fisher's test).

In order to visualize the localization of p53 in the A549 cells (nucleus vs. cytoplasm), p53 expression was additionally analyzed using indirect immunofluorescence. As assessed by using A549 staining with anti-p53 antibody followed by anti-IgG-FITC conjugated antibody, green fluorescence with nuclear localization was observed in the A549 cells treated with CIS, DTX alone or in combination with GV, SU, and/or vitamin D compound (Fig. 11). Thus, p53 was localized in the nucleus where it revealed the activity as a transcription factor; for example, it induced p21 expression as assessed by western blot analysis.

Analysis of expression of proteins involved in the activity and metabolism of vitamin D in A549 lung cancer cells. Vitamin D reveals its activity through binding with VDR, while the availability of vitamin D is regulated by 24-hydroxylase (CYP24), the enzyme that inactivates it (7). In this study, the expression level of VDR, as well as that of CYP24, was examined by western blot analysis to determine the possible cause of the weak activity of vitamin D compounds in A549 cells. Densitometric analysis revealed that $1,24(\mathrm{OH})_{2} \mathrm{D}_{3}(\mathrm{p}<0.05)$ and $1,25(\mathrm{OH})_{2} \mathrm{D}_{3}$ increased the expression of VDR in A549 cells. DTX when used alone, in turn, resulted in the downregulation of VDR compared to the untreated cells, but when $1,24(\mathrm{OH})_{2} \mathrm{D}_{3}$ or $1,25(\mathrm{OH})_{2} \mathrm{D}_{3}$ was used in combination with DTX, the level of VDR increased compared to treatment with DTX alone. A lower level of VDR expression was observed following incubation of the A549 cells with SU, DTX and vitamin D compounds compared to treatment with $\mathrm{SU}$ alone. No significant changes in VDR expression were observed in the cells treated with CIS used alone or in different combinations (Fig. 12A).

Treatment of the A549 cells with $1,24(\mathrm{OH})_{2} \mathrm{D}_{3}$ or $1,25(\mathrm{OH})_{2} \mathrm{D}_{3}$ resulted in the upregulation of CYP24 expression [statistically significant for $1,25(\mathrm{OH})_{2} \mathrm{D}_{3}$ ]. The upregulation of 

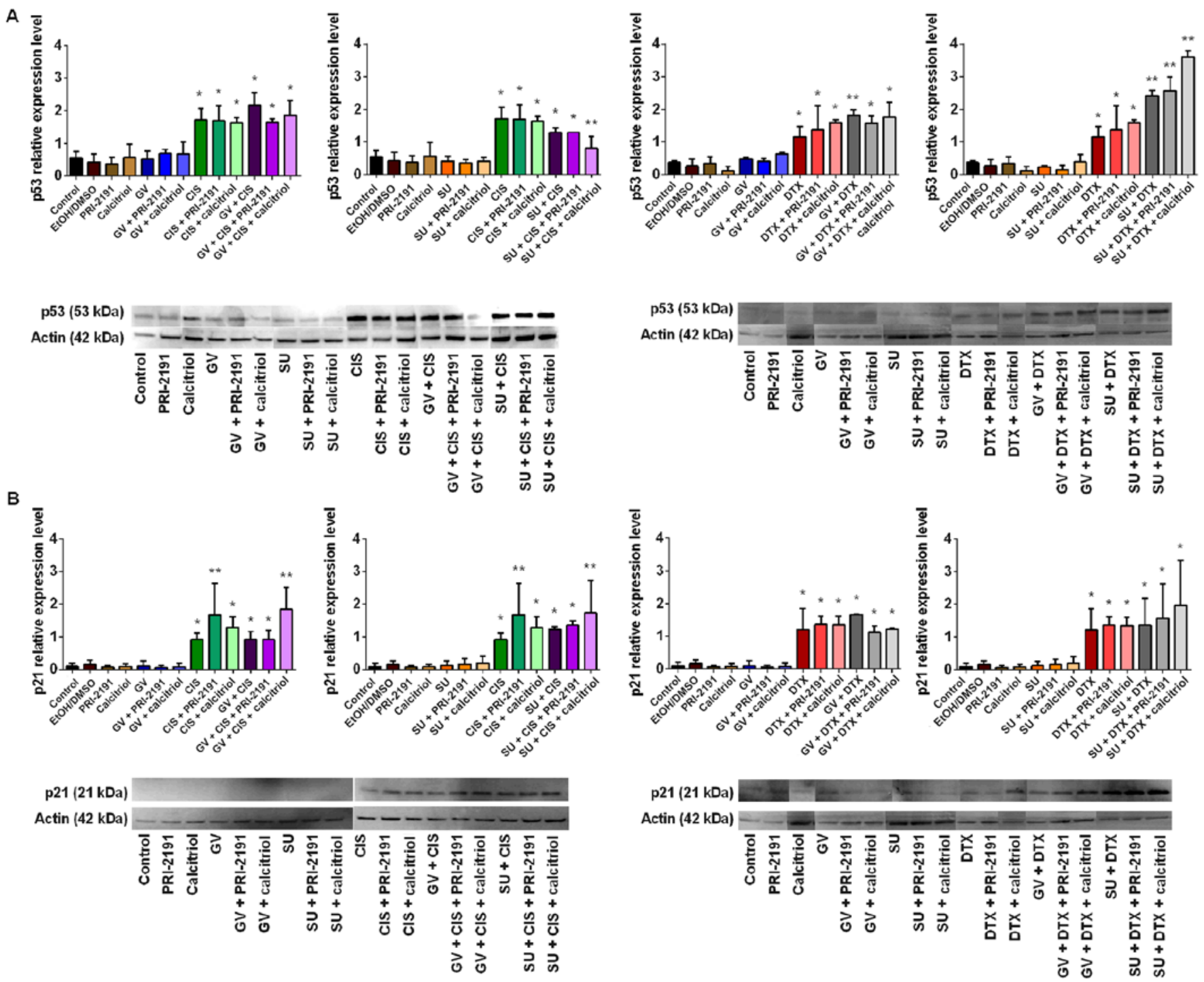

Figure 10. Effect of GV, SU, CIS, DTX, PRI-2191 and calcitriol on (A) p53 and (B) p21 expression in A549 cells. Densitometric analysis was performed using ImageJ $1.46 \mathrm{v}$ software; the results were normalized to actin; bars represent the means $\pm \mathrm{SD}, \mathrm{n}=2-3$ repeats. ${ }^{*} \mathrm{p}<0.05$, compared with control cells and TKI; ${ }^{*} \mathrm{p}<0.05$, compared with control cells, TKI, and CYT (one-way ANOVA, Fisher's test). Beneath the bar charts, representative immunoblots are presented. Note that not all the data samples were run continuously in adjacent lanes in the same gel, as portrayed in the figure. GV, imatinib; SU, sunitinib; CIS, cisplatin; DTX, docetaxel; PRI-2191, 1,24(OH $)_{2} \mathrm{D}_{3}$; Calcitriol, $1,25(\mathrm{OH})_{2} \mathrm{D}_{3}$.

CYP24 in the A549 cells was also observed following incubation with $\mathrm{GV}$ in combination with $1,24(\mathrm{OH})_{2} \mathrm{D}_{3}$ or $1,25(\mathrm{OH})_{2} \mathrm{D}_{3}$, and with GV together with CIS or DTX and vitamin D compounds. $1,24(\mathrm{OH})_{2} \mathrm{D}_{3}$ and $1,25(\mathrm{OH})_{2} \mathrm{D}_{3}$ in combination with CIS did not increase the level of CYP24. When used in combination with SU and DTX, vitamin D compounds caused a small, but not significant increase in the CYP24 expression level. The highest induction of CYP24 protein expression was observed when the A549 cells were incubated with GV in combination with CIS or DTX and with $1,24(\mathrm{OH})_{2} \mathrm{D}_{3}$ or $1,25(\mathrm{OH})_{2} \mathrm{D}_{3}$. Vitamin D compounds in combination with SU together with CIS significantly increased the CYP24 protein level compared to the cells treated with SU in combination with CIS (Fig. 12B).

$1,24(\mathrm{OH})_{2} \mathrm{D}_{3}$ and $1,25(\mathrm{OH})_{2} \mathrm{D}_{3}$ also increased the expression of VDR in the HLMECs. A statistically significant increase in the VDR protein expression level was observed following incubation of the HLMECs with the test vitamin D compounds in combination with SU or CIS or DTX or SU + CIS, SU + DTX or $\mathrm{GV}+\mathrm{CIS}$ or $\mathrm{GV}+\mathrm{DTX}\left(\mathrm{GV}+\mathrm{DTX}+1,25(\mathrm{OH})_{2} \mathrm{D}_{3}\right.$ was not significant) (Fig. 13A). Treatment of the HLMECs with $1,24(\mathrm{OH})_{2} \mathrm{D}_{3}$ or $1,25(\mathrm{OH})_{2} \mathrm{D}_{3}$ also resulted in an increase in the CYP24 expression level compared to the untreated cells. However, the expression level of CYP24 was lower when the endothelial cells were treated with the vitamin D compounds in combination with GV or GV + CIS compared to the cells treated with the vitamin D compounds alone. An increase in CYP24 expression was observed in the HLMECs following incubation with $1,24(\mathrm{OH})_{2} \mathrm{D}_{3}$ or $1,25(\mathrm{OH})_{2} \mathrm{D}_{3}$ in combination with SU, CIS, DTX or their combinations compared to the untreated cells and SU alone or CIS or DTX alone (Fig. 13B).

Analysis of the expression levels of TP53, VEGFA and MYC. The mRNA expression levels of TP53, VEGFA and MYC in the A549 cells following incubation with GV, SU, CIS, DTX, 1,24(OH) $)_{2} \mathrm{D}_{3}$ and $1,25(\mathrm{OH})_{2} \mathrm{D}_{3}$ and their combinations were analyzed by real-time PCR with the $\Delta \Delta \mathrm{Ct}$ method. The 

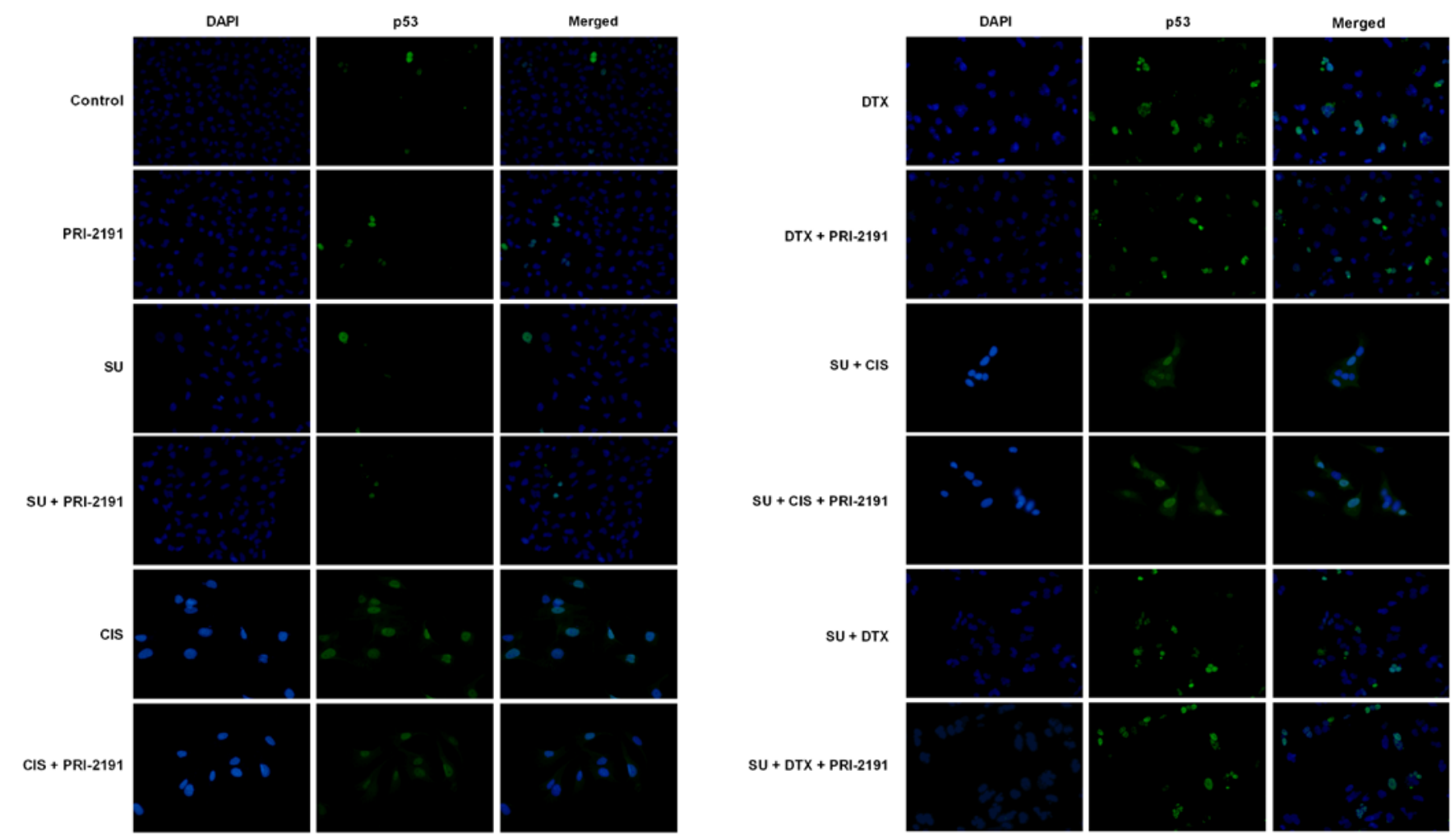

Figure 11. Effect of SU, CIS, DTX and PRI-2191 and their combinations on p53 expression and localization in A549 cells. A549 cells cultured on a coverglass were incubated with the tested combinations for $72 \mathrm{~h}$, then fixed, permeabilized and stained for p53 (FITC) and nuclear staining (DAPI). Representative images of the combinations of SU with CIS and DTX and PRI-2191 are shown. SU, sunitinib; CIS, cisplatin; DTX, docetaxel; PRI-2191, 1,24(OH) ${ }_{2} \mathrm{D}_{3}$
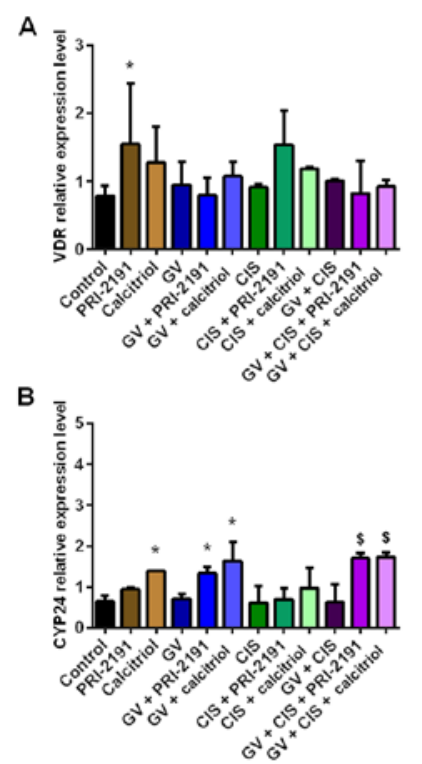

C

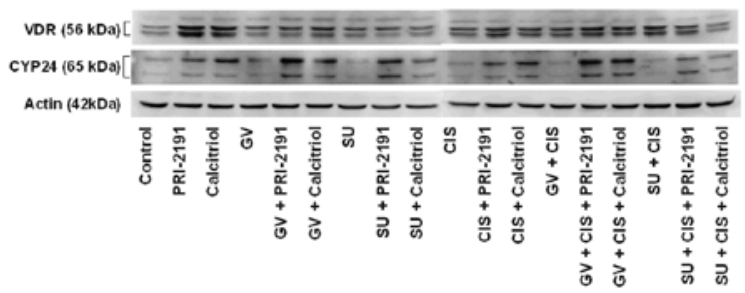

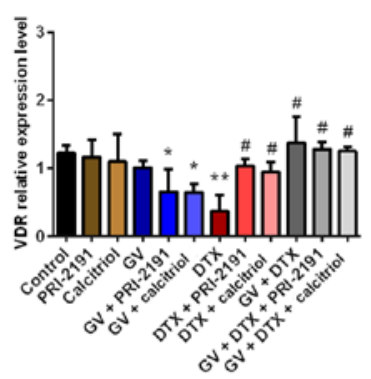
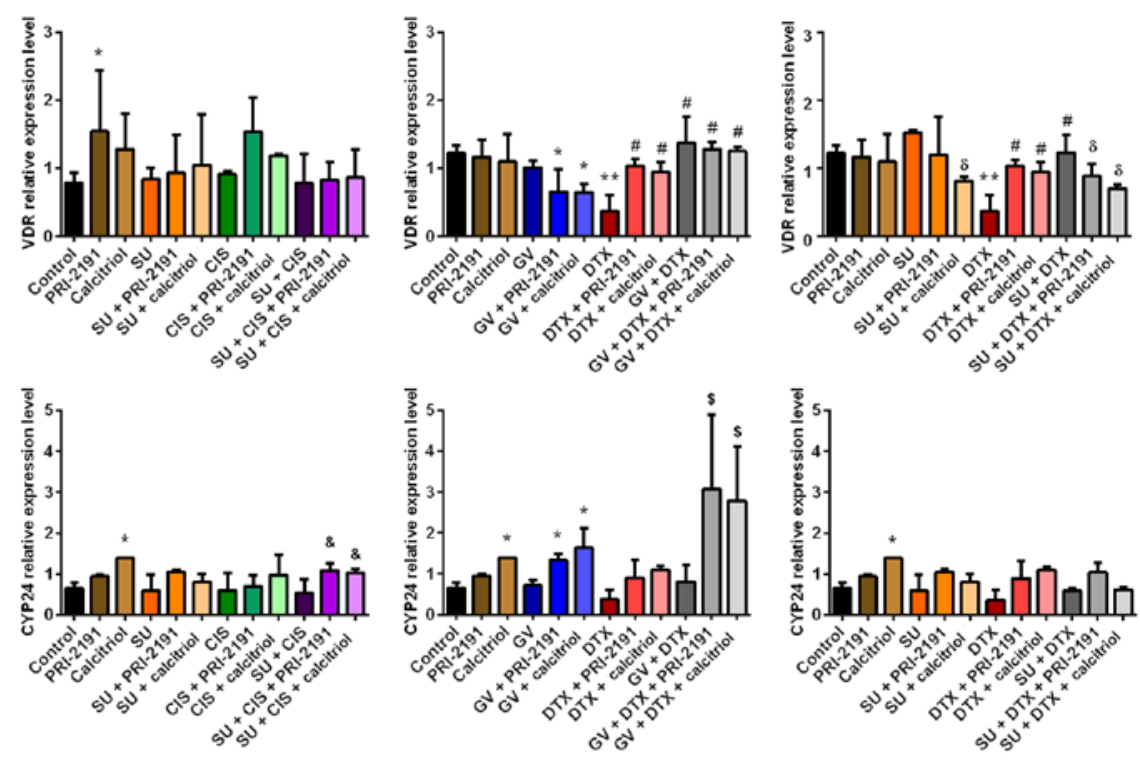

Figure 12. Effect of GV, SU, CIS, DTX, PRI-2191 and calcitriol on (A) VDR and (B) CYP24 expression in A549 cells. Densitometric analysis was performed using ImageJ 1.46v software; the results were normalized to actin; bars represent the means $\pm \mathrm{SD}, \mathrm{n}=3$ repeats. ${ }^{*} \mathrm{p}<0.05$, compared with control; ${ }^{* *} \mathrm{p}<0.05$, compared with control and TKI; ${ }^{\#} \mathrm{p}<0.05$, compared with CYT; ${ }^{8} \mathrm{p}<0.05$, compared with TKI; ${ }^{*} \mathrm{p}<0.05$, compared with TKI + CYT; ${ }^{\$} \mathrm{p}<0.05$, compared with, TKI, CYT, and TKI + CYT (one-way ANOVA, Fisher's test). (C) Beneath the bar charts, representative immunoblots are presented. Note that not all the data samples were run continuously in adjacent lanes in the same gel, as portrayed in the figure. PRI-2191, 1,24(OH) $\mathrm{D}_{3} ; \mathrm{Calcitriol}, 1,25(\mathrm{OH})_{2} \mathrm{D}_{3}$. 

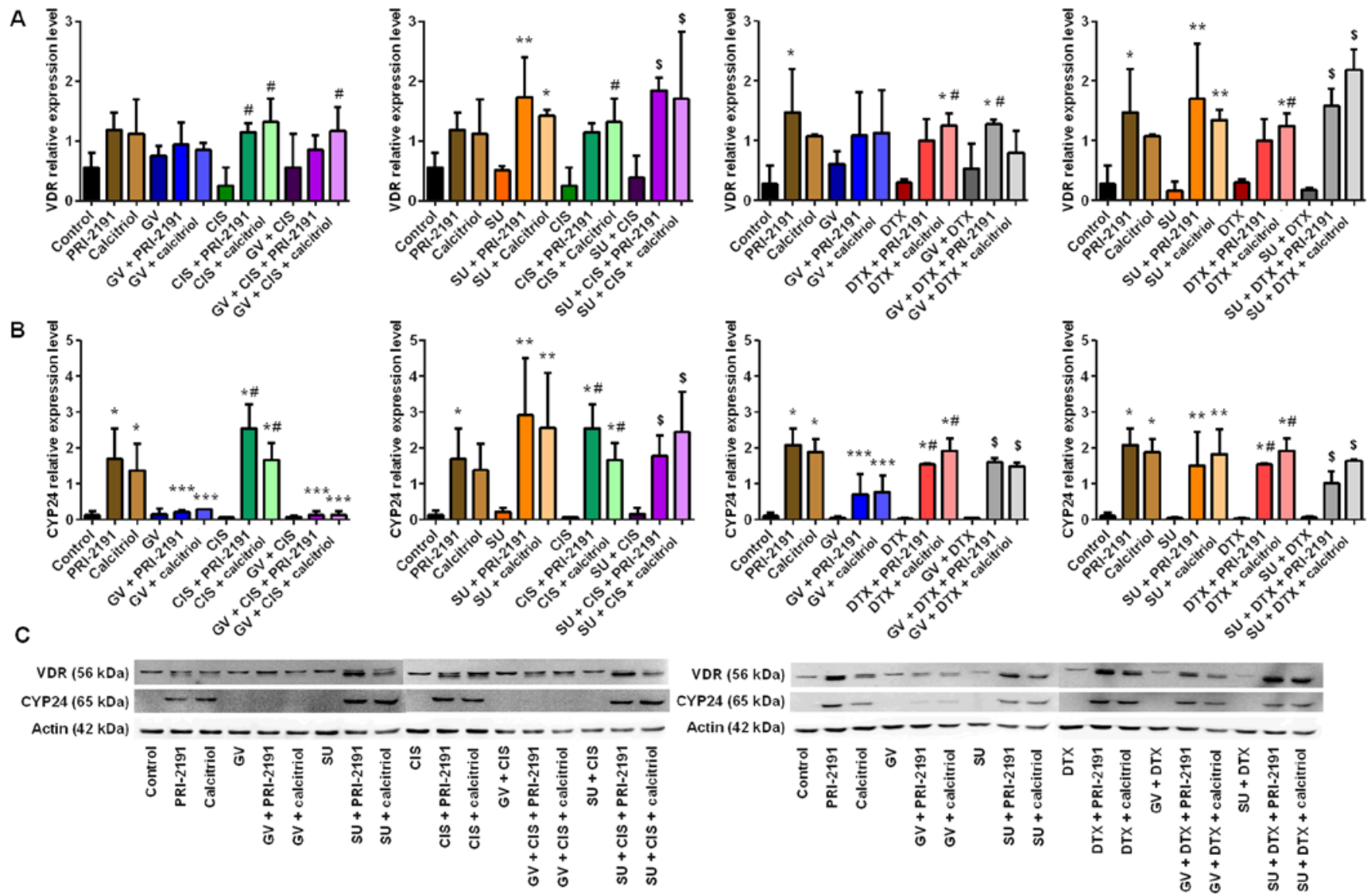

Figure 13. Effect of GV, SU, CIS, DTX, PRI-2191 and calcitriol on (A) VDR and (B) CYP24 expression in human lung microvascular endothelial cells (HLMECs). Densitometric analysis was performed using ImageJ 1.46v software; the results were normalized to actin; bars represent the means \pm SD, $\mathrm{n}=3$ repeats. " $\mathrm{p}<0.05$, compared with control; ${ }^{* *} \mathrm{p}<0.05$, compared with control and TKI; ${ }^{* * *} \mathrm{p}<0.05$, compared with vitamin D compounds; ${ }^{\sharp} \mathrm{p}<0.05$, compared with CYT; ${ }^{\$} \mathrm{p}<0.05$, compared with, TKI, CYT and TKI + CYT (one-way ANOVA, Fisher's test). (C) Beneath the bar charts, representative immunoblots are presented. Note that not all the data samples were run continuously in adjacent lanes in the same gel, as portrayed in the figure. PRI-2191, $1,24(\mathrm{OH})_{2} \mathrm{D}_{3}$; Calcitriol, $1,25(\mathrm{OH})_{2} \mathrm{D}_{3}$.

expression level of each studied mRNA was normalized to the expression level of RPLPO (selected as the most stable endogenous control gene, based on the screening analysis of 16 endogenous control candidates with the TaqMan Array Human Endogenous Control Panel array). GV, CIS and DTX did not affect the expression of TP53, VEGFA and MYC in the A549 cells, while SU significantly upregulated the expression of all the tested genes. The downregulation of TP53 in the A549 cells was observed following combined treatment with $\mathrm{GV}$, CIS and $1,24(\mathrm{OH})_{2} \mathrm{D}_{3}$ compared with the untreated and CIS-treated cells. When SU was used in combination with CIS and the vitamin D compounds or with DTX and $1,25(\mathrm{OH})_{2} \mathrm{D}_{3}$, the level of TP53 was lower compared with that in the cells treated with SU used alone (Fig. 14A). Similarly, CIS combined with SU prevented the increase in the VEGFA or MYC mRNA level caused by SU ( $<<0.05$, one-way ANOVA, Fisher's test) (Fig. 14B and C).

Sunitinib alone or in combination with docetaxel and $1,24(\mathrm{OH})_{2} \mathrm{D}_{3}$ inhibits 4549 tumor growth in vivo. Mice treated with SU and DTX with or without $1,24(\mathrm{OH})_{2} \mathrm{D}_{3}$ from D23 of the experiment had significantly smaller tumors than those in the control group mice and mice treated with $1,24(\mathrm{OH})_{2} \mathrm{D}_{3}$ alone. From D26, the mean tumor volume in the $\mathrm{SU}+1,24(\mathrm{OH})_{2} \mathrm{D}_{3^{-}}$- treated mice was significantly lower than that of the mice in the control group and mice treated with $1,24(\mathrm{OH})_{2} \mathrm{D}_{3}$ alone. Mice treated with SU alone had significantly smaller tumors than those of the control group mice on D23 and between D28 and $\mathrm{D} 47$, and compared with $1,24(\mathrm{OH})_{2} \mathrm{D}_{3}$ from $\mathrm{D} 26$ to the end of experiment. In addition, the mice treated with the triple combination of SU, DTX and $1,24(\mathrm{OH})_{2} \mathrm{D}_{3}$ were found to have significantly smaller tumors that the mice treated with DTX and DTX $+1,24(\mathrm{OH})_{2} \mathrm{D}_{3}$ from D23 of the experiment till the end. The mean tumor volume in the SU + DTX-treated group was significantly lower than that of the DTX-treated mice between D26 and D44 of the experiment (except for D42) and compared with DTX $+1,24(\mathrm{OH})_{2} \mathrm{D}_{3}$ from $\mathrm{D} 23$ to the final day of the experiment. In the case of the $\mathrm{SU}+1,24(\mathrm{OH})_{2} \mathrm{D}_{3}$-treated mice, the mean tumor volume was found to be significantly lower than that of the DTX-treated mice (D26 and D30) and the DTX $+1,24(\mathrm{OH})_{2} \mathrm{D}_{3}$-treated mice (D26-D30 and D35-D49 of the experiment), whereas the mean tumor volume of the SU-treated mice was significantly lower than that of the $\mathrm{DTX}+1,24(\mathrm{OH})_{2} \mathrm{D}_{3}$-treated mice between D23 and D49 of the experiment (except for D33) ( $\mathrm{p}<0.05$, Kruskal-Wallis test) (Fig. 15A).

We also performed a comparative statistical analysis of the 4 groups of mice treated with SU (alone or with different 

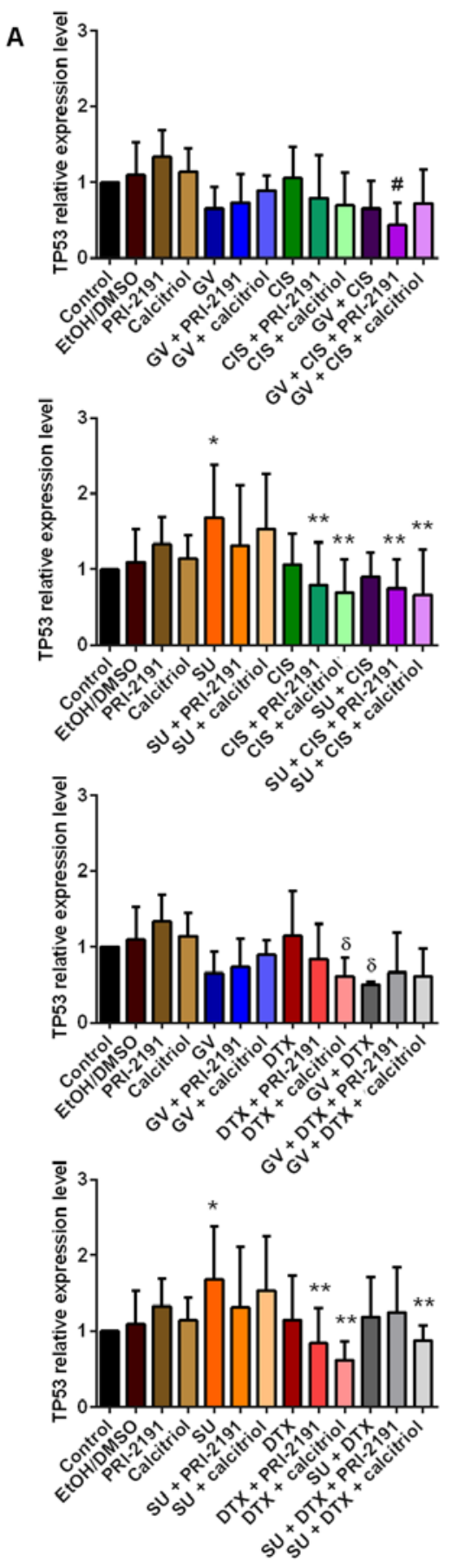
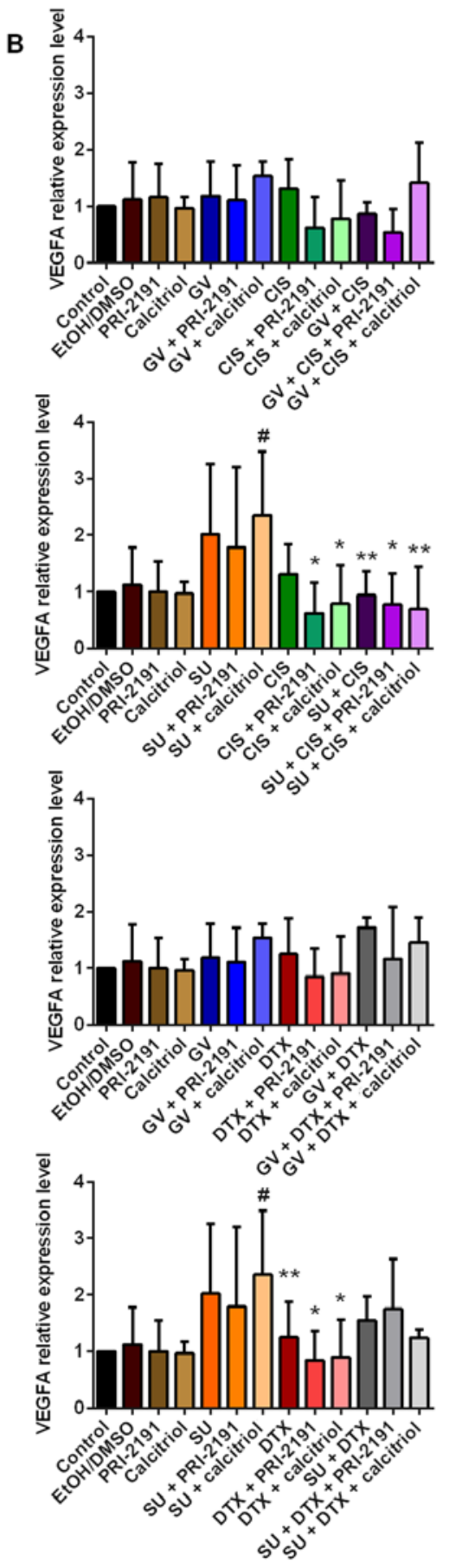
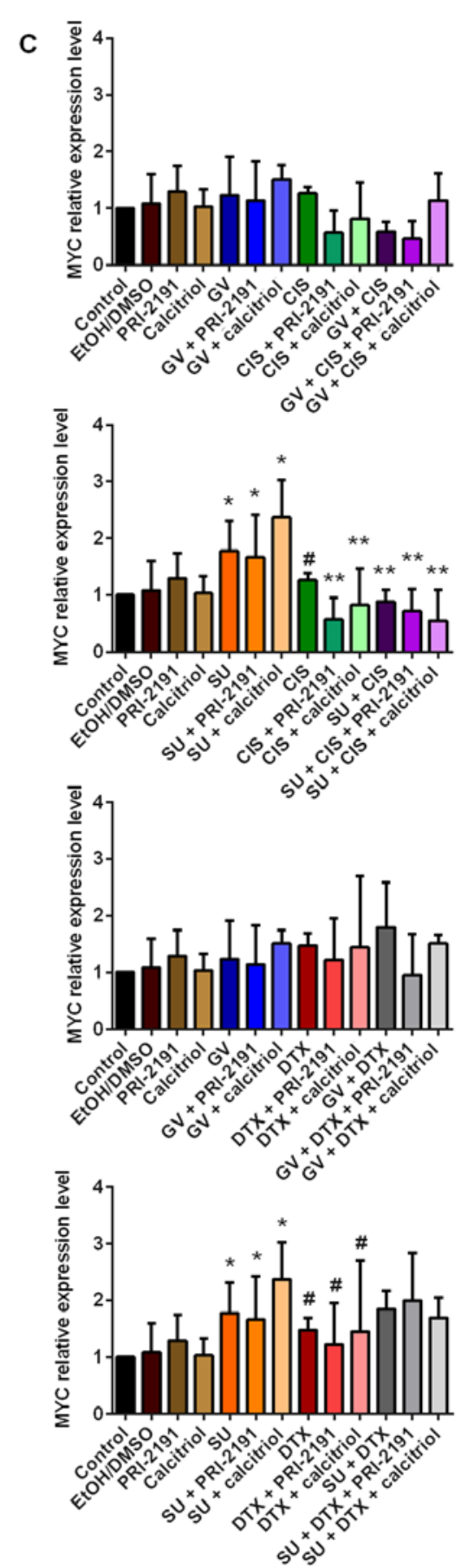

Figure 14. Real-time PCR analysis of (A) TP53, (B) VEGFA and (C) MYC levels in A549 cells after 72 h of incubation with GV, SU, CIS, DTX, PRI-2191 and calcitriol and their combinations. Bars represent relative quantification (RQ) calculated in Expression Suite v1.0.3 software with the $\Delta \Delta \mathrm{Ct}$ method. (A) ${ }^{*} \mathrm{p}<0.05$, compared with control; ${ }^{* *} \mathrm{p}<0.05$, compared with TKI; ${ }^{*} \mathrm{p}<0.05$, compared with control and CYT; ${ }^{8} \mathrm{p}<0.05$, compared with CYT; (B) ${ }^{\#} \mathrm{p}<0.05$, compared with control; ${ }^{*} \mathrm{p}<0.05$, compared with SU and SU + calcitriol; ${ }^{* *} \mathrm{p}<0.05$, compared with SU + calcitriol; (C) ${ }^{*} \mathrm{p}<0.05$, compared with control; ${ }^{* *} \mathrm{p}<0.05$, compared with SU and SU + vit; " ${ }^{p}<0.05$, compared with SU + calcitriol (one-way ANOVA, Fisher's test). GV, imatinib; SU, sunitinib; CIS, cisplatin; DTX, docetaxel; TKI, tyrosine kinase inhibitor; CYT, cytostatic drug; vit, vitamin D compound (PRI-2191, 1,24(OH) $\left.{ }_{2} \mathrm{D}_{3} ; \mathrm{Calcitriol}, 1,25(\mathrm{OH})_{2} \mathrm{D}_{3}\right)$.

combinations). According to the results, the mean tumor volume in the $\mathrm{SU}+\mathrm{DTX}+1,24(\mathrm{OH})_{2} \mathrm{D}_{3}$-treated mice was significantly lower than that of the mice receiving SU alone on D33, D37-D42, D49 and D51; and it was significantly lower than that of the $\mathrm{SU}+1,24(\mathrm{OH})_{2} \mathrm{D}_{3}$-treated mice on $\mathrm{D} 28$ and D33-D40 of the experiment $(\mathrm{p}<0.05$, Kruskal-Wallis test) (Fig. 15B).

On D51 of the experiment, tumors were harvested and weighted on a scale. Mice receiving $\mathrm{SU}+\mathrm{DTX}+1,24(\mathrm{OH})_{2} \mathrm{D}_{3}$ had the smallest tumors with a mean tumor mass of $0.271 \pm 0.065 \mathrm{~g}$, which was significantly lower than that of the mice in the control group, and the $1,24(\mathrm{OH})_{2} \mathrm{D}_{3}$, $\mathrm{DTX}+1,24(\mathrm{OH})_{2} \mathrm{D}_{3}(\mathrm{p}<0.01)$ and DTX-treated mice $(\mathrm{p}<0.05)$. The mean tumor mass in mice treated with SU + DTX and $\mathrm{SU}+1,24(\mathrm{OH})_{2} \mathrm{D}_{3}$ was $0.510 \pm 0.225$ and $0.412 \pm 0.152 \mathrm{~g}$, respectively, and was significantly lower than that of the mice in the control group $(\mathrm{p}<0.05)$ and $1,24(\mathrm{OH})_{2} \mathrm{D}_{3}(\mathrm{p}<0.01)$. The mean tumor mass in the mice treated with SU alone $(0.565 \pm 0.326 \mathrm{~g})$ 
A

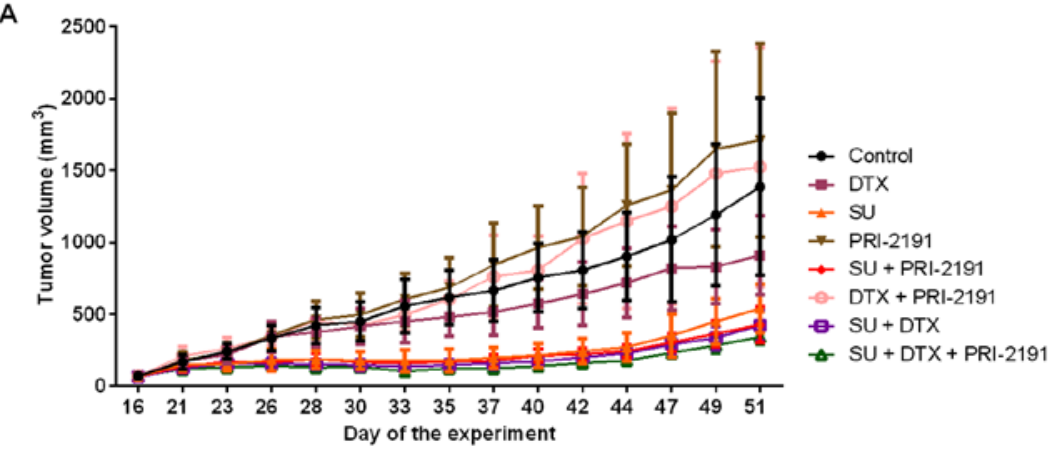

B
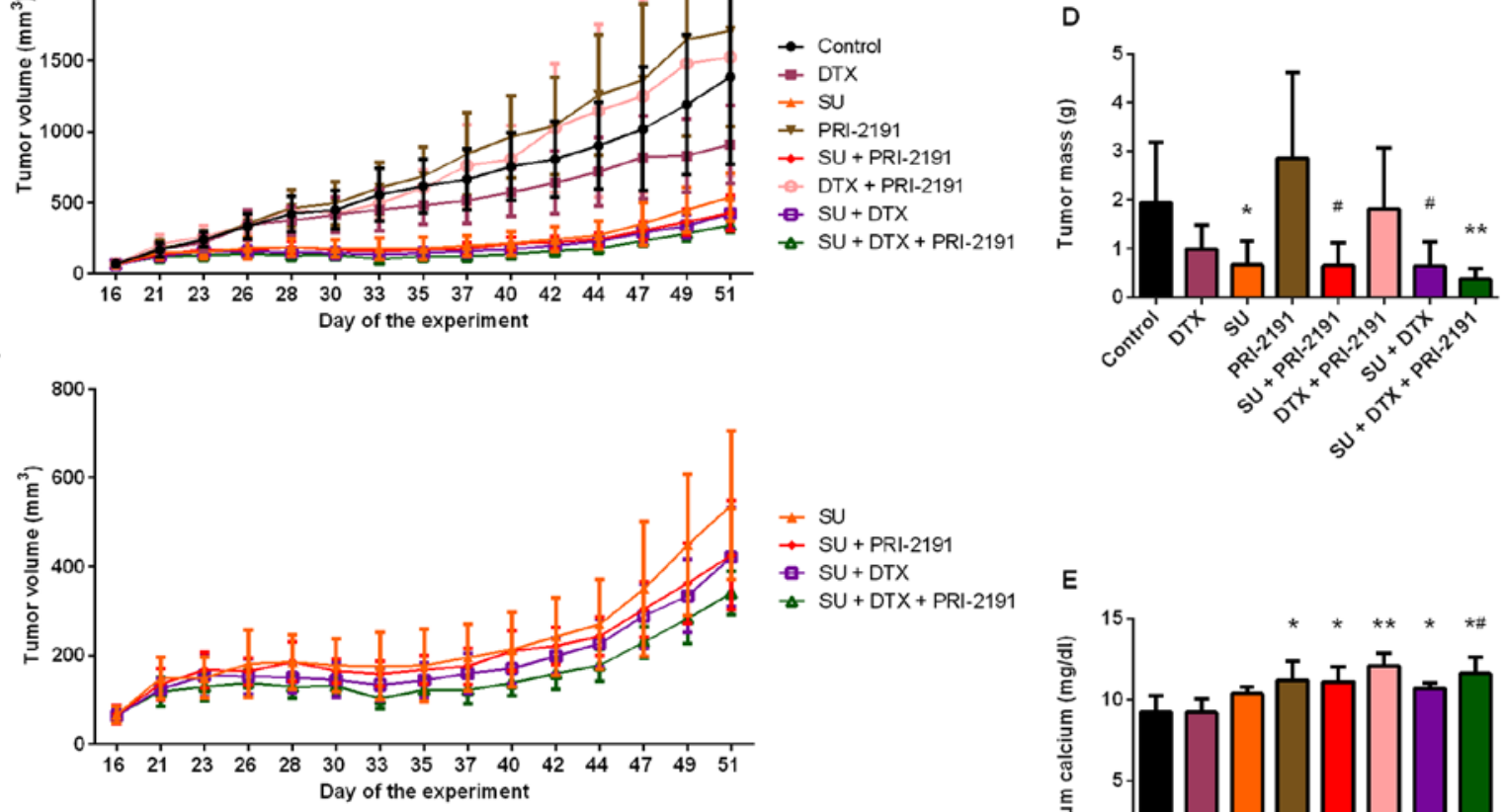

- SU
- SU + PRI-2191
* SU+DTX
- SU + DTX + PRI-2191

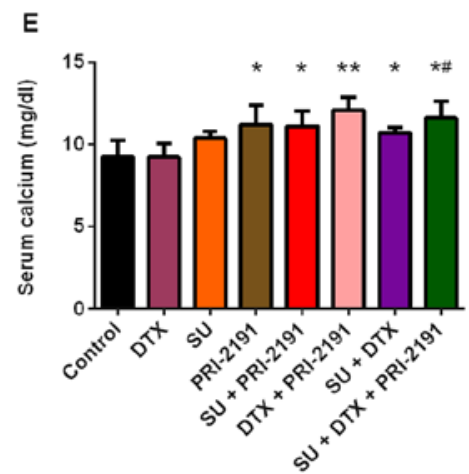

C

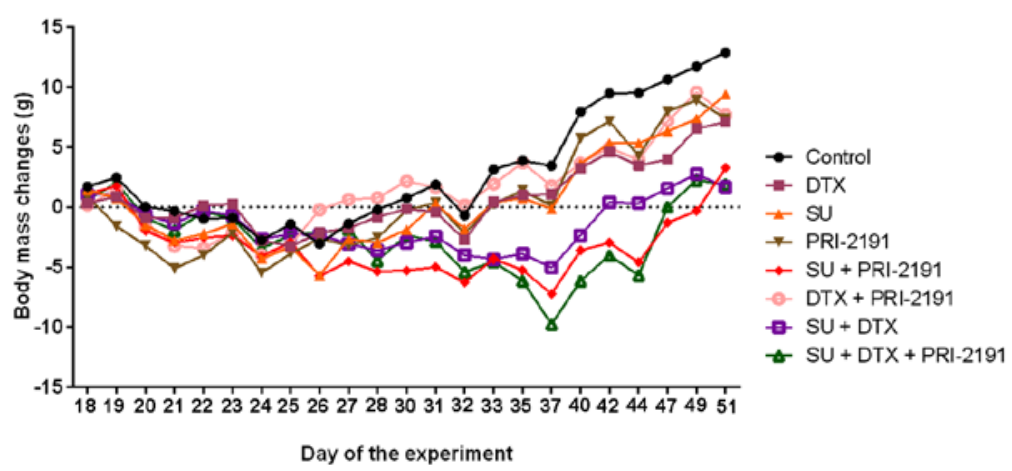

Figure 15. Antitumor activity of SU, DTX and vitamin D analog PRI-2191 in an A549 lung cancer model in vivo. SU was administered at the dose of $40 \mathrm{mg} / \mathrm{kg} /$ body weight daily, DTX at $5 \mathrm{mg} / \mathrm{kg} /$ body weight once a week, and PRI-2191 at $1 \mu \mathrm{g} / \mathrm{kg} / \mathrm{body}$ weight 3 times a week. (A) Kinetics of A549 tumor growth in all experimental groups; (B) comparison of groups receiving SU alone or in combination with DTX and/or PRI-2191; (C) body weight loss of mice bearing A549 tumors treated with SU, DTX, and/or vitamin D analog PRI-219; (D) comparison of tumor mass on the final day of the experiment [day (D)51]; ${ }^{*} \mathrm{p}<0.05$, compared to PRI-2191; ${ }^{\#} \mathrm{p}<0.05$, compared to control and PRI-2191 group; ${ }^{* *} \mathrm{p}<0.05$, compared to control, PRI-2191, DTX + PRI-2191, and DTX (Kruskal-Wallis test); (E) comparison of calcium concentration in serum collected from mice bearing A549 tumors on the final day of the experiment (D51) treated with SU, DTX, and/or vitamin D analog PRI-2191 alone or in combinations, ${ }^{*} \mathrm{p}<0.05$, compared to control group and DTX; ${ }^{* *} \mathrm{p}<0.05$, compared to control group, DTX, SU and SU + DTX, ${ }^{*} \mathrm{p}<0.05$, compared to SU (Tukey's test). SU, sunitinib; DTX, docetaxel; PRI-2191, 1,24(OH $)_{2} \mathrm{D}_{3}$.

was significantly lower than that of the $1,24(\mathrm{OH})_{2} \mathrm{D}_{3}$-treated mice $(\mathrm{p}<0.01)$ (Kruskal-Wallis test) (Fig. 15D).

Analysis of body weight loss during the experiment. To evaluate the possible toxic effects of the studied compounds, we measured the body mass of all mice during the experiment and performed hematological and biochemical analysis of the blood collected at the end of the experiment. The loss of body weight was observed during the experiment, but it did not exceed $10 \%$. In the mice treated with $\mathrm{SU}$ or $1,24(\mathrm{OH})_{2} \mathrm{D}_{3}$ alone, loss of body weight ranged from 3 to $6 \%$ (D24-D28). For the mice treated with $\mathrm{SU}+1,24(\mathrm{OH})_{2} \mathrm{D}_{3}$, loss of body weight was between 3-7\% from D21 and D44. Treatment with SU + DTX was well-tolerated; maximal body weight loss was found to be $5 \%$ on D37, whereas for the mice treated with SU + DTX $+1,24(\mathrm{OH})_{2} \mathrm{D}_{3}$, it was between $3-10 \%$ from D28 and D40. From
D37, the administration of SU and DTX was terminated, and the mice began to recover with a gain in body weight (Fig. 15C).

Analysis of internal organs. We did not observe any splenomegaly and hepatomegaly during the dissection of the animals at the end of the experiment or any macroscopic changes in the internal organs. However, there were some differences in liver mass between the following treatment groups: SU vs. control, $1,24(\mathrm{OH})_{2} \mathrm{D}_{3}$, and DTX $+1,24(\mathrm{OH})_{2} \mathrm{D}_{3}$ and $\mathrm{SU}+\mathrm{DTX}$ vs. DTX $+1,24(\mathrm{OH})_{2} \mathrm{D}_{3}$. The mean kidneys mass in the SU + DTX-treated mice was lower than that of the control group mice $(\mathrm{p}<0.05$, multiple comparison Kruskal-Wallis test) (Table V).

Hematological analysis of blood harvested from mice treated with $\mathrm{SU}, \mathrm{DTX}$ and $1,24(\mathrm{OH})_{2} \mathrm{D}_{3}$. We performed 
Table V. Analysis of the mass of different internal organs ( $\mathrm{g}$ ) harvested from mice treated with SU, DTX and vitamin D analog PRI-2191 at the end of the experiment [day (D)51].

\begin{tabular}{lccccc}
\hline Group/tissue & Liver $(\mathrm{g})$ & Spleen $(\mathrm{g})$ & Kidneys $(\mathrm{g})$ & Heart $(\mathrm{g})$ & Body mass on D51 $^{\mathrm{a}}(\mathrm{g})$ \\
\hline Control & $1.22 \pm 0.10$ & $0.100 \pm 0.061$ & $0.222 \pm 0.022$ & $0.274 \pm 0.033$ & $0.127 \pm 0.025$ \\
DTX & $1.16 \pm 0.09$ & $0.089 \pm 0.042$ & $0.193 \pm 0.029$ & $0.263 \pm 0.019$ & $0.121 \pm 0.021$ \\
SU & $1.05 \pm 0.07^{\mathrm{b}}$ & $0.083 \pm 0.030$ & $0.175 \pm 0.015^{\mathrm{d}}$ & $0.245 \pm 0.025$ & $0.111 \pm 0.013$ \\
PRI-2191 & $1.23 \pm 0.14$ & $0.160 \pm 0.071$ & $0.184 \pm 0.034$ & $0.255 \pm 0.042$ & $0.116 \pm 0.035$ \\
SU + PRI-2191 & $1.15 \pm 0.14$ & $0.104 \pm 0.069$ & $0.189 \pm 0.031$ & $0.238 \pm 0.035$ & $0.105 \pm 0.016$ \\
DTX + PRI-2191 & $1.27 \pm 0.16$ & $0.129 \pm 0.041$ & $0.198 \pm 0.045$ & $0.257 \pm 0.025$ & $0.107 \pm 0.028$ \\
SU + DTX & $1.02 \pm 0.17^{\mathrm{c}}$ & $0.105 \pm 0.026$ & $0.174 \pm 0.032^{\mathrm{d}}$ & $0.220 \pm 0.031^{\mathrm{d}}$ & $0.100 \pm 0.019$ \\
SU + DTX + PRI-2191 & $1.05 \pm 0.10$ & $0.098 \pm 0.028$ & $0.194 \pm 0.019$ & $0.240 \pm 0.031$ & $0.102 \pm 0.009$ \\
\hline
\end{tabular}

${ }^{\mathrm{a} D}$ 51, final day of experiment; ${ }^{\mathrm{b}}$ compared to control, PRI-2191, and DTX + PRI-2191; c compared to DTX + PRI-2191; ${ }^{\mathrm{d}}$ compared to control $(\mathrm{p}<0.05 \text {, multiple comparison Kruskal-Wallis test). SU, sunitinib; DTX, docetaxel; PRI-2191, 1,24(OH) })_{2} \mathrm{D}_{3}$.

Table VI. Analysis of red blood cell parameters in blood collected from mice treated with SU, DTX and/or vitamin D analog PRI-2191.

\begin{tabular}{|c|c|c|c|c|c|c|c|}
\hline Group/parameter & $\begin{array}{c}\mathrm{RBC} \\
\left(\mathrm{x} 10^{6} / \mu \mathrm{l}\right)\end{array}$ & $\begin{array}{l}\mathrm{Hgb} \\
(\mathrm{g} / \mathrm{dl})\end{array}$ & $\begin{array}{l}\mathrm{Ht} \\
(\%)\end{array}$ & $\begin{array}{l}\text { MCV } \\
\text { (fl) }\end{array}$ & $\begin{array}{c}\mathrm{MCH} \\
(\mathrm{pg})\end{array}$ & $\begin{array}{c}\mathrm{MCHC} \\
(\mathrm{g} / \mathrm{dl})\end{array}$ & $\begin{array}{c}\text { RDW } \\
(\%)\end{array}$ \\
\hline Control & $7.0 \pm 1.3$ & $12.6 \pm 1.4$ & $34.9 \pm 6.1$ & $50.2 \pm 3.4$ & $18.6 \pm 4.2$ & $37.2 \pm 8.7$ & $16.9 \pm 1.6$ \\
\hline DTX & $7.4 \pm 0.4$ & $13.3 \pm 0.6$ & $36.3 \pm 1.9$ & $49.1 \pm 1.0$ & $17.9 \pm 0.7$ & $36.5 \pm 0.8$ & $17.0 \pm 0.6$ \\
\hline SU & $6.6 \pm 1.7$ & $12.1 \pm 1.7$ & $34.3 \pm 3.7$ & $51.7 \pm 1.7^{\mathrm{b}}$ & $18.2 \pm 0.9^{d}$ & $35.1 \pm 1.9$ & $19.3 \pm 1.0^{\mathrm{e}}$ \\
\hline PRI-2191 & $6.6 \pm 1.0$ & $11.0 \pm 1.6^{a}$ & $30.6 \pm 4.8^{\mathrm{a}}$ & $46.5 \pm 2.0^{c}$ & $16.8 \pm 0.6^{c}$ & $36.3 \pm 1.2$ & $16.8 \pm 1.1$ \\
\hline SU + PRI-2191 & $6.5 \pm 0.7$ & $11.9 \pm 1.4$ & $33.3 \pm 3.7$ & $51.1 \pm 2.1$ & $18.3 \pm 0.9$ & $35.8 \pm 0.6$ & $18.8 \pm 0.7$ \\
\hline DTX + PRI-2191 & $7.5 \pm 1.3$ & $12.8 \pm 2.1$ & $35.9 \pm 5.7$ & $47.9 \pm 1.5$ & $17.1 \pm 0.4$ & $35.7 \pm 1.2$ & $17.7 \pm 1.0$ \\
\hline $\mathrm{SU}+\mathrm{DTX}$ & $6.6 \pm 0.7$ & $12.0 \pm 1.3$ & $33.7 \pm 3.6$ & $50.8 \pm 1.2^{b}$ & $18.1 \pm 0.3$ & $35.6 \pm 0.4$ & $19.8 \pm 1.5^{\mathrm{e}}$ \\
\hline SU + DTX + PRI-2191 & $6.7 \pm 0.7$ & $12.1 \pm 1.0$ & $33.5 \pm 2.7$ & $49.8 \pm 1.8$ & $17.9 \pm 0.7$ & $36.1 \pm 0.4$ & $19.1 \pm 0.7^{\mathrm{e}}$ \\
\hline
\end{tabular}

RBC, red blood cell; Hgb, hemoglobin; Ht, hematocrit; MCV, mean corpuscular volume; MCH, mean corpuscular hemoglobin; MCHC, mean corpuscular hemoglobin concentration; RDW, red blood cell distribution width. ${ }^{\mathrm{a}}$ Compared to DTX; ${ }^{\mathrm{b}}$ compared to DTX + PRI-2191; ${ }^{c}$ compared to SU, SU + PRI-2191 and SU + DTX; ${ }^{\mathrm{d}}$ compared to PRI-2191 and DTX+PRI-2191; ${ }^{\mathrm{e}}$ compared to control, DTX and PRI-2191 ( $\mathrm{p}<0.05 ;$ Kruskal-Wallis test). Bold font indicates statistical significance.

hematological analysis of blood collected from all mice. No significant changes in red blood cell (RBC) count were observed between the treatment groups. The mean hemoglobin $(\mathrm{Hgb})$ concentration and hematocrit $(\mathrm{Ht})$ were found to be the highest in the DTX-treated mice and differed significantly from those of the $1,24(\mathrm{OH})_{2} \mathrm{D}_{3}$-treated mice: $\mathrm{Hgb}, 13.25 \pm 0.57 \mathrm{~g} / \mathrm{dl}$; and $\mathrm{Ht}, 36.34 \pm 1.92 \%$ for DTX-treated mice; and $\mathrm{Hgb}, 11.05 \pm 1.58 \mathrm{~g} / \mathrm{dl}$; and $\mathrm{Ht}, 30.57 \pm 4.76 \%$ for $1,24(\mathrm{OH})_{2} \mathrm{D}_{3}$-treated mice. Furthermore, statistical analysis revealed that the mean corpuscular volume (MCV) and mean corpuscular hemoglobin $(\mathrm{MHC})$ in the $1,24(\mathrm{OH})_{2} \mathrm{D}_{3}$ treated mice were significantly lower than those of the SU-, $\mathrm{SU}+1,24(\mathrm{OH})_{2} \mathrm{D}_{3}$ - and $\mathrm{SU}+\mathrm{DTX}$-treated mice. In addition, the MCV in the SU- and SU + DTX-treated mice was significantly higher than that of the DTX $+1,24(\mathrm{OH})_{2} \mathrm{D}_{3}$-treated mice. In case of $\mathrm{MCH}$, statistically significant difference was found between SU and DTX $+1,24(\mathrm{OH})_{2} \mathrm{D}_{3}$-treated mice. Moreover, hematological analysis indicated that the red blood cell distribution width (RDW) in the SU-, SU + DTX- and $\mathrm{SU}+\mathrm{DTX}+1,24(\mathrm{OH})_{2} \mathrm{D}_{3}$-treated mice was higher than that of the mice in the control group, and the DTX- and $1,24(\mathrm{OH})_{2} \mathrm{D}_{3}$ treated mice $(\mathrm{p}<0.05$, Kruskal-Wallis test). No significant differences were found in the case of the mean corpuscular hemoglobin concentration (MCHC) between the experimental groups (Table VI).

In the case of the white blood cell (WBC) count, we found that treatment with $1,24(\mathrm{OH})_{2} \mathrm{D}_{3}$ resulted in a higher count than that of the control group and SU-treated mice, and also resulted in a higher number of lymphocytes (Lymph) compared with the control group. Moreover, treatment with $1,24(\mathrm{OH})_{2} \mathrm{D}_{3}$ resulted in a significantly higher number of granulocytes (Gran) and monocytes (Mono) in peripheral blood compared with the $\mathrm{SU}$ and $\mathrm{SU}+1,24(\mathrm{OH})_{2} \mathrm{D}_{3}$-treated mice. Treatment with $1,24(\mathrm{OH})_{2} \mathrm{D}_{3}$ also resulted in a significantly higher number of granulocytes compared to the control group and DTX group ( $p<0.05$, Kruskal-Wallis test). A significantly higher 
Table VII. Analysis of white blood cell parameters in blood collected from mice treated with SU, DTX and/or vitamin D analog PRI-2191.

\begin{tabular}{|c|c|c|c|c|c|c|c|}
\hline Group/parameter & $\begin{array}{c}\text { WBC } \\
\left(\times 10^{3} / \mu 1\right)\end{array}$ & $\begin{array}{c}\text { Lymph } \\
\left(\mathrm{x} 10^{3} / \mu 1\right)\end{array}$ & $\begin{array}{c}\text { Mono } \\
\left(\mathrm{x} 10^{3} / \mu 1\right)\end{array}$ & $\begin{array}{c}\text { Gran } \\
\left(\times 10^{3} / \mu 1\right)\end{array}$ & $\begin{array}{c}\text { Lymph } \\
(\%)\end{array}$ & $\begin{array}{c}\text { Mono } \\
(\%)\end{array}$ & $\begin{array}{c}\text { Gran } \\
(\%)\end{array}$ \\
\hline Control & $6.5 \pm 3.7$ & $2.4 \pm 1.2$ & $1.0 \pm 0.4$ & $3.2 \pm 2.4$ & $37.4 \pm 8.1$ & $16.8 \pm 4.1$ & $45.8 \pm 8.9$ \\
\hline DTX & $7.7 \pm 4.6$ & $3.5 \pm 1.8$ & $1.1 \pm 0.8$ & $3.1 \pm 2.5$ & $47.9 \pm 15.9$ & $15.0 \pm 4.0$ & $37.1 \pm 12.9$ \\
\hline SU & $5.6 \pm 2.3$ & $2.7 \pm 1.2$ & $0.8 \pm 0.4$ & $2.1 \pm 1.0$ & $48.9 \pm 9.1$ & $14.7 \pm 3.8$ & $36.5 \pm 6.8$ \\
\hline PRI-2191 & $13.6 \pm 5.7^{\mathrm{a}}$ & $4.9 \pm 1.8^{\mathrm{a}}$ & $2.1 \pm 1.1^{b}$ & $6.7 \pm 3.1^{b}$ & $36.9 \pm 6.0$ & $14.9 \pm 2.6$ & $48.2 \pm 6.2^{d}$ \\
\hline SU + PRI-2191 & $6.8 \pm 2.6$ & $3.7 \pm 1.7$ & $0.9 \pm 0.4$ & $2.2 \pm 1.2$ & $53.9 \pm 10.8^{c}$ & $13.9 \pm 4.5$ & $32.2 \pm 9.2$ \\
\hline DTX + PRI-2191 & $9.4 \pm 2.2$ & $3.7 \pm 1.0$ & $1.3 \pm 0.5$ & $4.3 \pm 1.7$ & $40.2 \pm 9.1$ & $14.3 \pm 3.4$ & $45.6 \pm 10.5$ \\
\hline SU + DTX & $7.1 \pm 1.5$ & $3.0 \pm 0.5$ & $1.2 \pm 0.3$ & $2.9 \pm 0.8$ & $42.5 \pm 4.4$ & $16.8 \pm 1.5$ & $40.7 \pm 3.9$ \\
\hline SU + DTX + PRI-2191 & $7.9 \pm 2.3$ & $3.9 \pm 1.0$ & $1.3 \pm 0.5$ & $2.7 \pm 0.9$ & $50.6 \pm 5.5^{c}$ & $16.1 \pm 2.2$ & $33.2 \pm 3.4^{c}$ \\
\hline
\end{tabular}

WBC, white blood cell; Lymph, lymphocytes; Mono, monocytes; Gran, granulocytes. ${ }^{\mathrm{a} C o m p a r e d}$ to control and SU; ${ }^{\mathrm{b}}$ compared to SU and SU + PRI-2191; ' compared to control and PRI-2191; ${ }^{\mathrm{d}}$ compared to SU ( $\mathrm{p}<0.05$, Kruskal-Wallis test). Bold font indicates statistical significance.

Table VIII. Analysis of platelets parameters in blood collected from mice treated with SU, DTX and/or vitamin D analog PRI-2191.

\begin{tabular}{|c|c|c|c|c|}
\hline Group/parameter & $\operatorname{PLT}\left(\times 10^{3} / \mu 1\right)$ & MPV (fl) & PDW (fl) & $\mathrm{PCT}(\%)$ \\
\hline Control & $1270.9 \pm 233.4$ & $5.1 \pm 0.4$ & $14.8 \pm 1.6$ & $0.65 \pm 0.12$ \\
\hline DTX & $1202.2 \pm 186.6$ & $5.1 \pm 0.3$ & $15.2 \pm 1.8$ & $0.61 \pm 0.11$ \\
\hline SU & $1142.5 \pm 184.0$ & $5.2 \pm 0.2$ & $14.4 \pm 1.7$ & $0.59 \pm 0.09$ \\
\hline PRI-2191 & $1345.9 \pm 183.9$ & $5.5 \pm 0.2^{\mathrm{a}}$ & $18.3 \pm 2.5^{\mathrm{c}}$ & $0.74 \pm 0.10$ \\
\hline SU + PRI-2191 & $1181.3 \pm 176.8$ & $5.2 \pm 0.3$ & $14.6 \pm 1.9$ & $0.62 \pm 0.11$ \\
\hline DTX + PRI-2191 & $1010.1 \pm 292.2$ & $5.5 \pm 0.2^{b}$ & $19.5 \pm 4.1^{\mathrm{d}}$ & $0.55 \pm 0.15$ \\
\hline SU + DTX & $1260.5 \pm 212.5$ & $5.5 \pm 0.2^{\mathrm{a}}$ & $16.2 \pm 1.7$ & $0.69 \pm 0.12$ \\
\hline SU + DTX + PRI-2191 & $1301.1 \pm 224.8$ & $5.4 \pm 0.2$ & $16.0 \pm 2.0$ & $0.70 \pm 0.12$ \\
\hline
\end{tabular}

PLT, platelets; MPV, mean platelet volume; PDW, platelet distribution width; PCT, plateletcrit. ${ }^{\mathrm{a} C o m p a r e d ~ t o ~ c o n t r o l ; ~}{ }^{\mathrm{b}}$ compared to control and DTX; 'compared to control and SU; ${ }^{\mathrm{d}}$ compared to control, SU and SU + PRI-2191 ( $\mathrm{p}<0.05$, Kruskal-Wallis test). Bold font indicates statistical significance.

percentage of lymphocytes and lower percentage of granulocytes was observed in blood collected from mice treated with a combination of SU and $1,24(\mathrm{OH})_{2} \mathrm{D}_{3}$ with or without DTX compared with the mice in the control group and mice treated with $1,24(\mathrm{OH})_{2} \mathrm{D}_{3}$ alone [Gran only in the case of triple combination of SU $+\mathrm{DTX}+1,24(\mathrm{OH})_{2} \mathrm{D}_{3}$ ]. The percentage of Gran in the $1,24(\mathrm{OH})_{2} \mathrm{D}_{3}$-treated mice was significantly higher than that of the SU-treated mice. No significant differences were observed in the percentage of monocytes between the treatment groups ( $\mathrm{p}<0.05$, Kruskal-Wallis test) (Table VII).

The analysis of platelet parameters revealed no significant changes in the number of platelets (PLT) and plateletcrit (PCT) between the experimental groups. However, we found that the mean platelet volume (MPV) in the SU + DTX-, $1,24(\mathrm{OH})_{2} \mathrm{D}_{3}$ - and DTX $+1,24(\mathrm{OH})_{2} \mathrm{D}_{3}$-treated mice was significantly higher than that of the control group mice and DTX-treated mice (DTX only in case of DTX $+1,24(\mathrm{OH})_{2} \mathrm{D}_{3}$ ). In addition, the $1,24(\mathrm{OH})_{2} \mathrm{D}_{3}$ - and DTX $+1,24(\mathrm{OH})_{2} \mathrm{D}_{3}$-treated mice were characterized by a higher platelet distribution width
(PDW), the parameter reflecting how uniform the platelets are in size, than that of the control group mice, and SU- and $\mathrm{SU}+1,24(\mathrm{OH})_{2} \mathrm{D}_{3}$-treated mice (only for DTX $+1,24(\mathrm{OH})_{2} \mathrm{D}_{3}$ ) ( $\mathrm{p}<0.05$, Kruskal-Wallis test) (Table VIII).

Biochemical analysis of blood harvested from mice treated with $S U, D T X$ and $1,24(\mathrm{OH})_{2} D_{3}$. The lowest serum calcium level was found to be in the control group and DTX-treated mice, $9.25 \pm 1.00$ and $9.25 \pm 0.82 \mathrm{mg} / \mathrm{dl}$, respectively, whereas the highest concentration $(12.09 \pm 0.76 \mathrm{mg} / \mathrm{dl})$ was found to be in the DTX $+1,24(\mathrm{OH})_{2} \mathrm{D}_{3}$-treated mice and was significantly higher than the control group mice and DTX-, SU-, or $\mathrm{SU}+$ DTX-treated mice. The mean serum calcium concentration was found to be in mice treated with $1,24(\mathrm{OH})_{2} \mathrm{D}_{3}$, $\mathrm{SU}+1,24(\mathrm{OH})_{2} \mathrm{D}_{3}, \mathrm{SU}+\mathrm{DTX}$, and $\mathrm{SU}+\mathrm{DTX}+1,24(\mathrm{OH})_{2} \mathrm{D}_{3}$, which was significantly higher than the control group and DTX-treated mice. In addition, mice treated with the triple combination of SU, DTX and $1,24(\mathrm{OH})_{2} \mathrm{D}_{3}$ had a significantly higher level of serum calcium than that of the SU-treated 
mice $(11.62 \pm 1.00$ and $10.38 \pm 0.40 \mathrm{mg} / \mathrm{dl}$, respectively) ( $<<0.05$, Tukey's test) (Fig. 15E). No significant changes were observed in the phosphate levels between the treatment groups (Table IX). In addition, no significant changes were observed for alanine (ALT) and aspartate (AST) aminotransferase activity, as well as the total bilirubin content. The highest alkaline phosphatase (ALP) activity was noted in the mice treated with $\mathrm{SU}$ and $\mathrm{SU}+\mathrm{DTX}+1,24(\mathrm{OH})_{2} \mathrm{D}_{3}$ (57.8 \pm 15.7 and $59.0 \pm 15.9 \mathrm{U} / 1$, respectively), which differed significantly compared to that of the $1,24(\mathrm{OH})_{2} \mathrm{D}_{3}$-treated mice $(34.5 \pm 10.0 \mathrm{U} / \mathrm{l})(\mathrm{p}<0.05$, Kruskal-Wallis test $)$. The mice treated with SU + DTX had a significantly higher plasma urea concentration $(8.15 \pm 1.33 \mathrm{mmol} / \mathrm{l})$ than that of the DTX-treated mice ( $p<0.05$, Kruskal-Wallis test). In the case of uric acid, the statistically significant higher level of plasma uric acid was observed in the $1,24(\mathrm{OH})_{2} \mathrm{D}_{3}$-treated mice compared with the control group mice $(196.6 \pm 28.3$ and $274.1 \pm 48.6 \mu \mathrm{mol} / 1$, respectively) ( $<<0.05$, Tukey's test) (Table IX). No significant changes were observed in the case of the creatinine concentration.

The lowest total cholesterol concentration was found to be in the $1,24(\mathrm{OH})_{2} \mathrm{D}_{3}$-treated mice $(1.96 \pm 0.39 \mathrm{mmol} / \mathrm{l})$, which was significantly lower than that of the mice treated with the triple combination of SU, DTX, and $1,24(\mathrm{OH})_{2} \mathrm{D}_{3}$ $(2.52 \pm 0.21 \mathrm{mmol} / \mathrm{l})(\mathrm{p}<0.05$, Kruskal-Wallis test). No significant changes were observed in the case of the plasma glucose concentration and lactate dehydrogenase (LDH) activity between the experimental groups (Table IX).

$S U$ and $1,24(\mathrm{OH})_{2} D_{3}$ downregulate VEGF-A expression in A549 tumors. The analysis of VEGF-A expression in A549 tumor lysates using ELISA revealed that treatment with $1,24(\mathrm{OH})_{2} \mathrm{D}_{3}$ alone or in combination with $\mathrm{SU}$, as well as $\mathrm{SU}$ and DTX resulted in the downregulation of VEGF-A expression. The mean VEGF-A level in these A549 tumor homogenates was significantly lower than that of the DTX-treated mice and control group mice [only $\mathrm{SU}+1,24(\mathrm{OH})_{2} \mathrm{D}_{3}$ ] (one-way ANOVA followed by Fisher's test). In addition, the mice treated with SU alone and SU + DTX $+1,24(\mathrm{OH})_{2} \mathrm{D}_{3}$ had a lower mean VEGF-A level in their tumors compared with the control group and DTX-treated mice, although the difference was not statistically significant (Fig. 16A).

We performed ELISA to detect the levels of PDGF-BB in the tumor homogenates. The lowest level of PDGF-BB was found to be in tumors harvested from the mice treated with $\mathrm{SU}+\mathrm{DTX}+1,24(\mathrm{OH})_{2} \mathrm{D}_{3}(34.4 \pm 22.7 \mathrm{pg} / \mathrm{mg}$ total protein $)$; however, this was not statistically significant when compared to the other experimental groups (one-way ANOVA followed by Fisher's test) (Fig. 16B).

Western blot analysis of tumor lysates. We performed western blot analysis to detect the expression of VDR and enzymes involved in the metabolism of vitamin $\mathrm{D}$, such as 1 $\alpha$-hydroxylase CYP27B1 and 24-hydroxylase CYP24. Densitometric analysis revealed no significant differences in VDR levels in the A549 tumor homogenates between the experimental groups (Fig. 17A). In the case of proteins involved in the metabolism of vitamin $\mathrm{D}$, we observed that the levels of CYP27B1 were significantly upregulated in tumor lysates obtained from the DTX $+1,24(\mathrm{OH})_{2} \mathrm{D}_{3}$-treated mice when

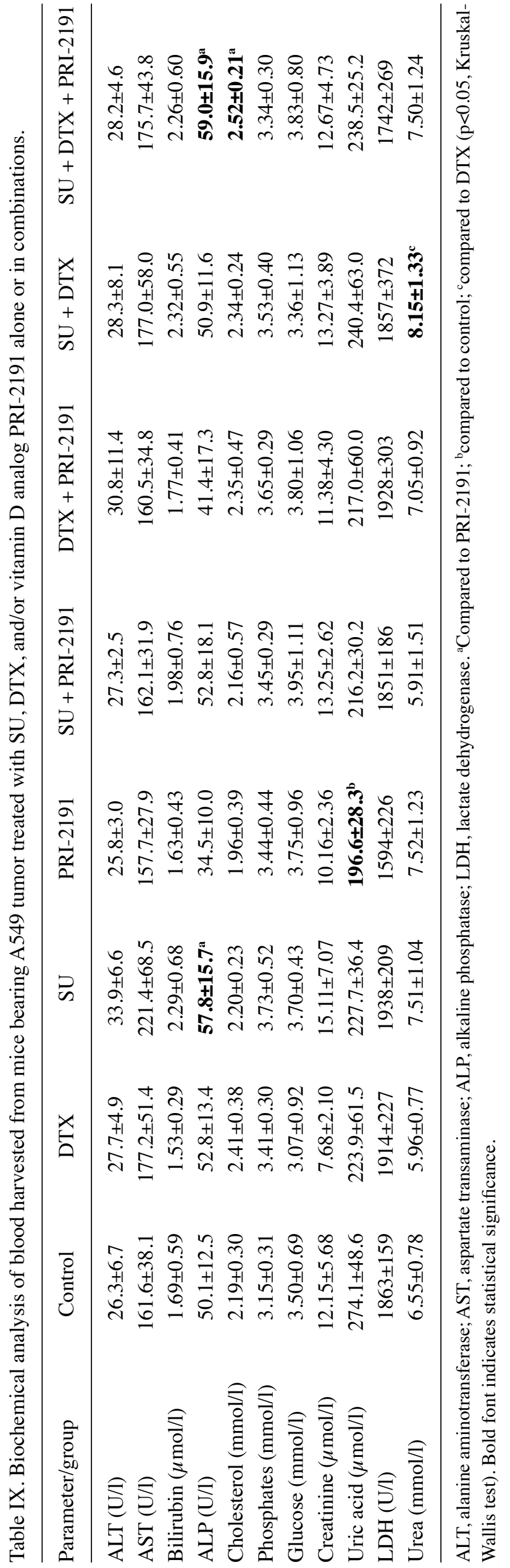



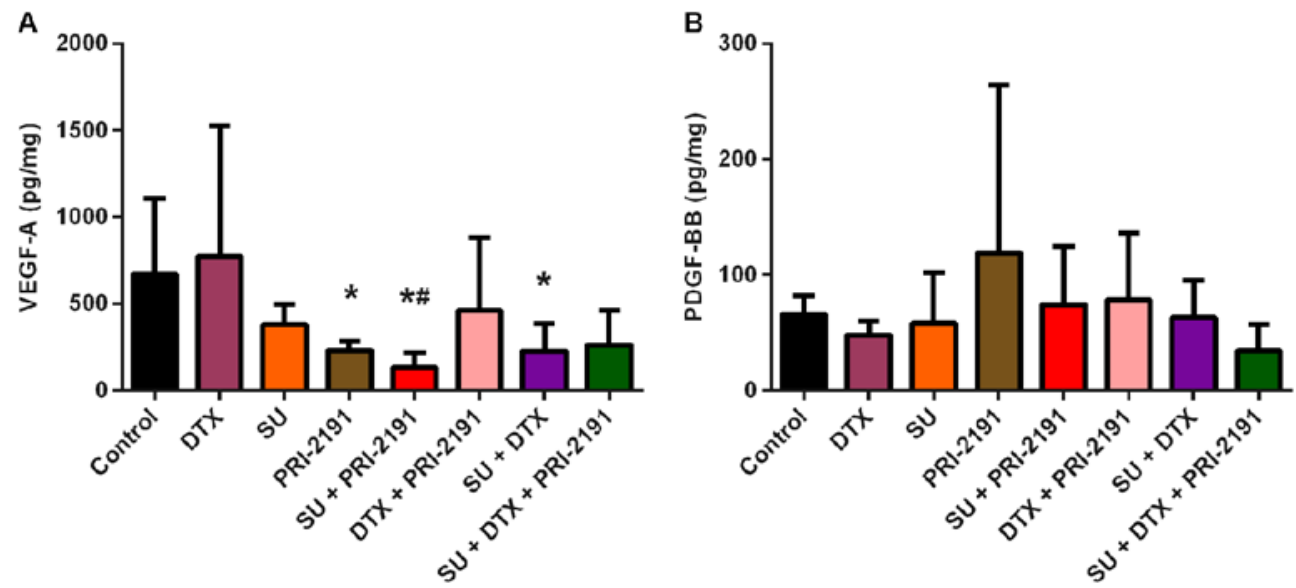

Figure 16. (A) VEGF-A and (B) PDGF-BB expression in A549 tumor lysates harvested from mice treated with SU, DTX, and PRI-2191 at the end of the experiment (D51). VEGF-A and PDGF-BB levels were normalized to the total protein concentration; bars represent the means \pm SD; " $\mathrm{p}<0.05$, compared to DTX; $\mathrm{p}<0.05$, compared to control group (one-way ANOVA followed by Fisher's test) (n=4 lysates in each group). SU, sunitinib; DTX, docetaxel; PRI-2191, 1,24(OH) ${ }_{2} \mathrm{D}_{3}$.

compared to those from mice treated with $\mathrm{SU}, 1,24(\mathrm{OH})_{2} \mathrm{D}_{3}$ and SU + DTX $+1,24(\mathrm{OH})_{2} \mathrm{D}_{3}$ (Fig. 17B). However, the expression of CYP24 was downregulated in the tumors harvested from the mice treated with $\mathrm{SU}+\mathrm{DTX}+1,24(\mathrm{OH})_{2} \mathrm{D}_{3}$, which was statistically significant when compared to the mice treated with DTX, SU + 1,24(OH $)_{2} \mathrm{D}_{3}$, DTX $+1,24(\mathrm{OH})_{2} \mathrm{D}_{3}$ and $\mathrm{SU}+\mathrm{DTX}$ (Fig. 17C) $(\mathrm{p}<0.05$, one-way ANOVA followed by Fisher's test).

We also analyzed the expression of NF- $\kappa$ B and I $\kappa$ B in A549 tumor lysates. Densitometric analysis revealed that $\mathrm{NF}-\kappa \mathrm{B}$ was downregulated in the $1,24(\mathrm{OH})_{2} \mathrm{D}_{3}$-treated mice when compared to the control group mice, although this difference was not statistically significant. However, the upregulation of NF- $\kappa \mathrm{B}$ was observed in the SU-, SU + DTX [compared to $\left.1,24(\mathrm{OH})_{2} \mathrm{D}_{3}\right]$ - and $\mathrm{SU}+\mathrm{DTX}+1,24(\mathrm{OH})_{2} \mathrm{D}_{3}$ treated mice [compared to the control, DTX, 1,24(OH $)_{2} \mathrm{D}_{3}$ and $\mathrm{DTX}+1,24(\mathrm{OH})_{2} \mathrm{D}_{3}$-treated mice] $(\mathrm{p}<0.05$, one-way ANOVA followed by Fisher's test) (Fig. 17D). In addition, treatment with $\mathrm{SU}+\mathrm{DTX}+1,24(\mathrm{OH})_{2} \mathrm{D}_{3}$ resulted in the downregulation of I $\kappa \mathrm{B}$ when compared with the control, SU-, SU + 1,24(OH) $)_{2} \mathrm{D}_{3^{-}}$, and DTX $+1,24(\mathrm{OH})_{2} \mathrm{D}_{3}$-treated mice $(\mathrm{p}<0.05$, one-way ANOVA followed by Fisher's test) (Fig. 17E).

Treatment with $1,24(\mathrm{OH})_{2} \mathrm{D}_{3}$ alone or in combination with DTX resulted in the upregulation of PTEN expression in the A549 tumor lysates. The administration of $1,24(\mathrm{OH})_{2} \mathrm{D}_{3}$ alone resulted in a significant increase in PTEN expression compared to all the experimental groups except for the $\mathrm{DTX}+1,24(\mathrm{OH})_{2} \mathrm{D}_{3}$-treated mice, whereas the administration of $1,24(\mathrm{OH})_{2} \mathrm{D}_{3}$ in combination with DTX caused a significant upregulation in PTEN expression when compared to the 4 groups treated with $\mathrm{SU}$ ( $\mathrm{p}<0.05$, one-way ANOVA followed by Fisher's test) (Fig. 17F).

Western blot analysis of Bcl-2 expression in the A549 tumor lysates revealed no significant differences between the experimental groups (Fig. 17G). However, it was observed that treatment with SU + DTX with or without $1,24(\mathrm{OH})_{2} \mathrm{D}_{3}$ upregulated Bax expression (bands running at approximately $40 \mathrm{kDa}$ probably corresponding to a Bax dimer) compared to control, DTX, SU, 1,24(OH) ${ }_{2} \mathrm{D}_{3}$, and DTX $+1,24(\mathrm{OH})_{2} \mathrm{D}_{3}$ treated mice and when compared to $\mathrm{SU}+1,24(\mathrm{OH})_{2} \mathrm{D}_{3}$ for
$\mathrm{SU}+\mathrm{DTX}+1,24(\mathrm{OH})_{2} \mathrm{D}_{3}(\mathrm{p}<0.05$, one-way ANOVA followed by Fisher's test) (Fig. 17H).

\section{Discussion}

Studies regarding the use of vitamin D in the prevention and treatment of malignant diseases began when it was discovered that $1,25(\mathrm{OH})_{2} \mathrm{D}_{3}$ exhibits anti-proliferative activity against cancer cells, and that patients suffering from cancer often have a decreased level of serum 25-hydroxyvitamin $\mathrm{D}_{3}$ (an indicator of nutritional status of vitamin $\mathrm{D})$. In vitro studies have demonstrated that $1,25(\mathrm{OH})_{2} \mathrm{D}_{3}$ inhibits the proliferation of different types of cancer cells, including lung cancer cells, and in vivo studies have indicated that $1,25(\mathrm{OH})_{2} \mathrm{D}_{3}$ inhibits tumor growth and metastasis. Vitamin $\mathrm{D}$ also potentiates the anticancer activity of several known cytostatic drugs. These data indicate vitamin $\mathrm{D}$ may be a promising agent for use in anticancer therapies $(13,40)$.

In this in vitro study, we observed that the addition of $1,24(\mathrm{OH})_{2} \mathrm{D}_{3}$ to the combination of imatinib with cisplatin to the A549 cell culture resulted in the transformation of an additive effect into synergism, while for combinations with docetaxel, only additive or antagonistic effects were observed. In a previous study using HL-60 promyelocytic leukemia cells, $1,24(\mathrm{OH})_{2} \mathrm{D}_{3}$ was shown to enhance the activity of imatinib alone and imatinib in combination with cisplatin or docetaxel, and $1,24(\mathrm{OH})_{2} \mathrm{D}_{3}$ also transformed the additive effect of imatinib and cytostatic interaction to synergism (41). In the case of sunitinib in combination with cisplatin and vitamin D compounds, synergistic interaction was observed, but with docetaxel, similar to the case of imatinib, the interaction was additive or antagonistic. Pan et al demonstrated that the interaction of sunitinib with docetaxel on A549 cells depends on the order in which the drugs are applied to the cells. They also assessed that synergism can be achieved when docetaxel is applied $24 \mathrm{~h}$ prior to the addition of sunitinib (42).

The potentiation of the anticancer activity of different drugs by vitamin $\mathrm{D}$ compounds has also studied in other cancer models; for example, $1,25(\mathrm{OH})_{2} \mathrm{D}_{3}$ was shown to increase the anti-metastatic activity of vaccine consisting 
A
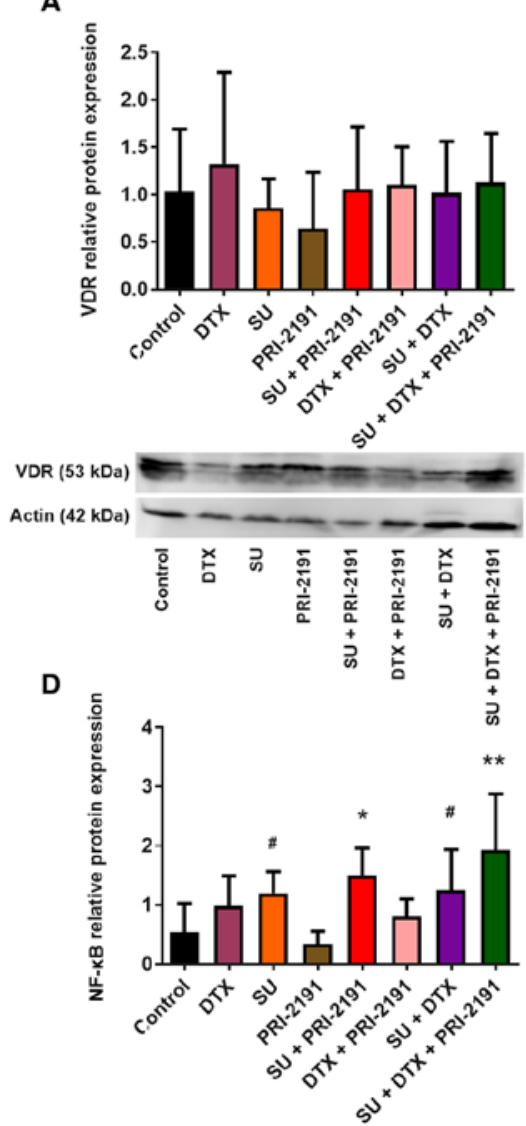

NF-KB ${ }^{(1050 \text { kDa) }}$

Actin (42 kDa)

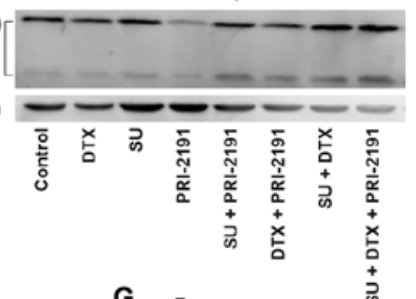

G
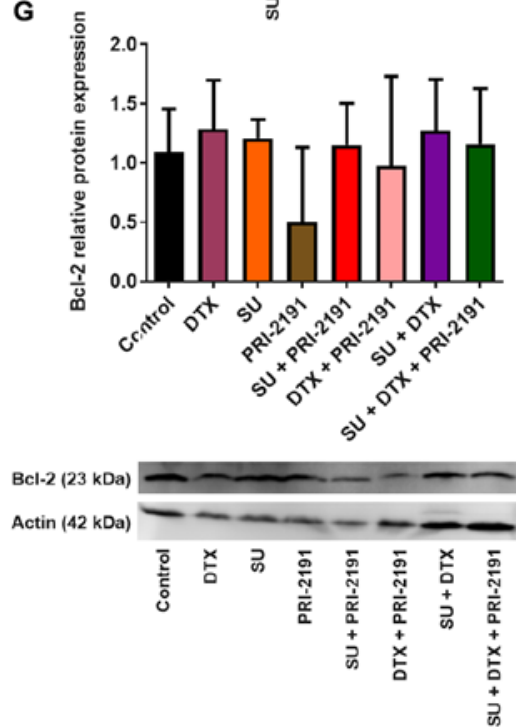

B

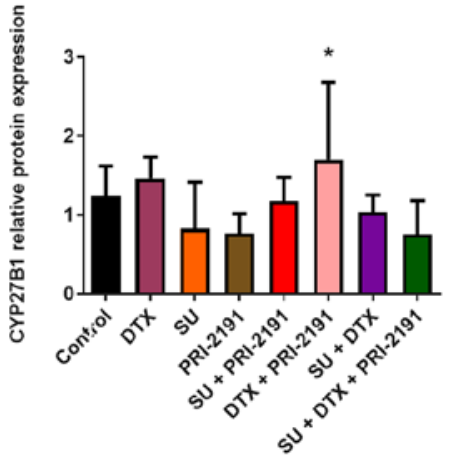

E

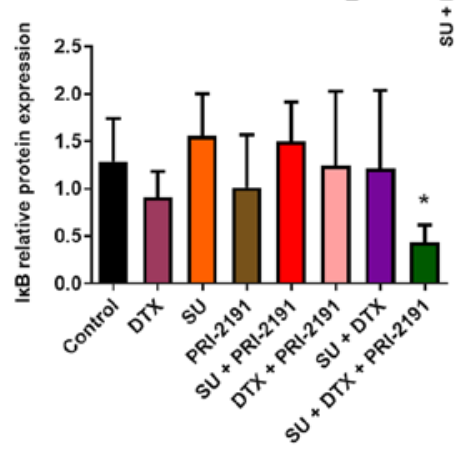

IKB (40 kDa)

Actin (42 kDa)

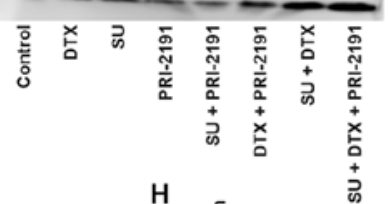

C

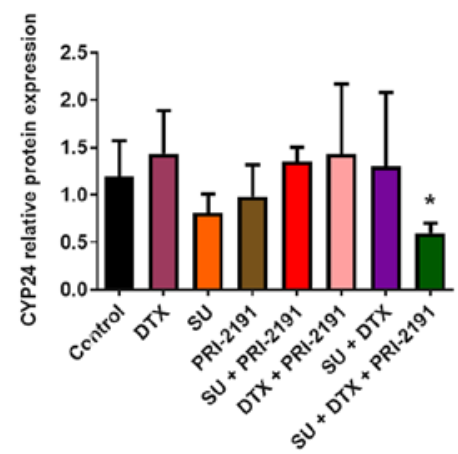

CYP24 (65 kDa)

Actin (42 kDa)

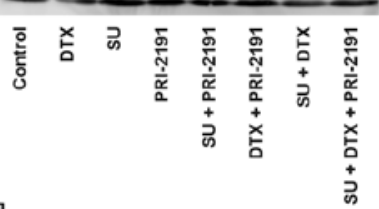

F

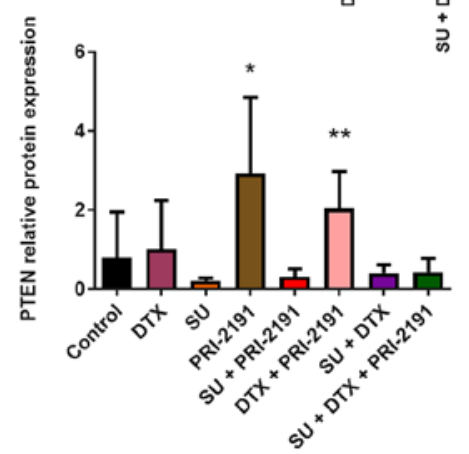

PTEN (55 kDa)

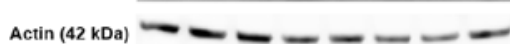

Actin (42 kDa)

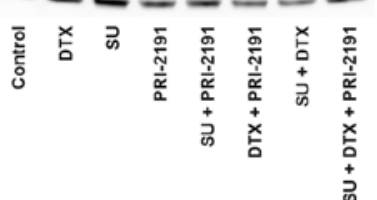

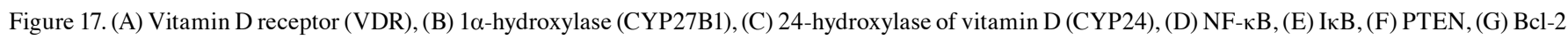
and $(\mathrm{H})$ Bax expression in A549 tumor lysates harvested from mice treated with SU, DTX and vitamin D analog PRI-2191 at the end of experiment (D51). Densitometric analysis was performed in ImageJ 1.46v software; blots were normalized to actin; means \pm SD, n=3-4 lysates in each group; (B) "p $<0.05$, compared to SU, PRI-2191, and SU + DTX + PRI-2191; (C) "p<0.05, compared to DTX, SU + PRI-2191, DTX + PRI-2191 and SU + DTX; (D) " p<0.05, compared to PRI-2191; "p $<0.05$, compared to control and PRI-2191; ${ }^{* *}$ p $<0.05$, compared to control, DTX, PRI-2191 and DTX + PRI-2191; (E) *p<0.05, compared to control, SU, SU + PRI-2191 and DTX + PRI-2191; (F) "p<0.05, compared to control, DTX, SU, SU + PRI-2191, SU + DTX and SU + DTX + PRI-2191; ** $\mathrm{p}<0.05$, compared to all groups receiving SU (alone or in combinations with DTX and PRI-2191); (H) *p<0.05, compared to control, DTX, SU and PRI-2191, DTX + PRI-2191 and SU + PRI-2191 (only for SU + DTX + PRI-2191) (one-way ANOVA followed by Fisher's test). Beneath the bar charts representative immunoblots are presented. SU, sunitinib; DTX, docetaxel; PRI-2191, 1,24(OH $)_{2} \mathrm{D}_{3}$. 
of murine beta-defensin-2 (mBD-2) and 3LL cell lysate in a murine model of LLC. Vitamin D analogs also potentiated the anticancer activity of cisplatin in an LLC model or 5 -fluorouracil (5-FU) in a murine and human colon cancer model $(26,29,30,43)$. However, the combination of vitamin D analogs with cisplatin in a murine model of LLC was shown to result in toxicity that manifested in body weight loss, leucopenia and hypercalcemia (26). Therefore, in this in vivo study using a A549 lung cancer model, we decided to explore docetaxel as a third agent in triple-combination therapy.

In lung cancer, the signaling pathways of VEGF and PDGF are often dysregulated, which is associated with a worse prognosis. In a preclinical study, it was demonstrated that the simultaneous inhibition of receptors for both VEGF and PDGF by sunitinib was beneficial in anticancer treatment (44). In this study, we demonstrated that sunitinib significantly inhibited A549 tumor growth, and the effect of sunitinib was potentiated by $1,24(\mathrm{OH})_{2} \mathrm{D}_{3}$, which is concurrent to the results of our previous study on imatinib using a A549 lung cancer model (31). Chemotherapy with sunitinib, similar to other drugs aimed at multiple targets, is often accompanied by certain adverse effects (19). In turn, combining sunitinib at low doses with other chemotherapeutic agents can prevent undesirable side-effects and can simultaneously achieve synergism in the drug-drug interaction (24). In this study, to the best of our knowledge, we demonstrate for the first time the use of a triple treatment scheme in a NSCLC A549 model, in which sunitinib, docetaxel and $1,24(\mathrm{OH})_{2} \mathrm{D}_{3}$ were employed together. Cytotoxic drugs, such as docetaxel, that have been used typically in anticancer therapy at the maximum tolerated dose (MTD), are also toxic to normal healthy cells. However, when the drug is administered more frequently and at lower doses, the so-called metronomic doses, it causes an 'anti-angiogenic side effect'. Moreover, such a therapy scheme appears to be more effective than the MTD schedule (45-47). Therefore, in this study, we decided to use docetaxel at 3 -fold lower doses in our experiments. In addition, the type of interaction between sunitinib and docetaxel depends on the sequence in which agents are added to culture cells, and that synergism can be observed when docetaxel is applied $24 \mathrm{~h}$ prior to sunitinib (42). Therefore, in this study, we administered docetaxel first, followed by sunitinib and then $1,24(\mathrm{OH})_{2} \mathrm{D}_{3}$. Triple combination therapy, consisting of sunitinib, docetaxel and $1,24(\mathrm{OH})_{2} \mathrm{D}_{3}$ revealed a more potent A549 tumor growth inhibitory effect than that of single- or double-drug scheme.

In order to achieve the therapeutic effect of sunitinib or other small molecule kinase inhibitors, chemotherapeutic agents must be administered daily for an extended period of time as terminating TKI administration may result in a rapid relapse. However, the continuous usage of TKIs may result in adverse effects, such as fatigue, body weight loss, neutropenia, hepatotoxicity, neurotoxicity, cardiotoxicity and others $(48,49)$. The toxicity of the triple combination of sunitinib, docetaxel and $1,24(\mathrm{OH})_{2} \mathrm{D}_{3}$, as assessed by body weight loss, was not found to be higher than that of sunitinib in combination with $1,24(\mathrm{OH})_{2} \mathrm{D}_{3}$ or with docetaxel. In addition, the toxicity of the triple combination did not differ from the toxicity of sunitinib used alone, particularly at the beginning of the experiment. The application of triple-compound therapy did not influence the serum calcium level in comparison to $1,24(\mathrm{OH})_{2} \mathrm{D}_{3}$ used alone, as well as no significant changes in main biochemical or morphological parameters of blood, which also suggests that some toxicity of tested treatment scheme was observed. The toxicity of $1,24(\mathrm{OH})_{2} \mathrm{D}_{3}$ in comparison to that of $1,25(\mathrm{OH})_{2} \mathrm{D}_{3}$ in terms of calcium deposits was analyzed previously (50). Histological analysis then revealed that the injection of $1,24(\mathrm{OH})_{2} \mathrm{D}_{3}$ or $1,25(\mathrm{OH})_{2} \mathrm{D}_{3}$ at a dose of $10 \mu \mathrm{g} / \mathrm{kg} /$ day s.c. resulted in moderate calcification of the kidneys and heart (50), while in the present study, $1,24(\mathrm{OH})_{2} \mathrm{D}_{3}$ was administered at a lower dose of $1 \mu \mathrm{g} / \mathrm{kg} /$ day.

$1,25(\mathrm{OH})_{2} \mathrm{D}_{3}$ and vitamin $\mathrm{D}$ derivatives may induce apoptosis through interaction with pro-apoptotic and antiapoptotic pathways; for example, $1,25(\mathrm{OH})_{2} \mathrm{D}_{3}$ has been shown to increase the level of the pro-apoptotic protein, Bak, which belongs to the Bcl-2 family, or to decrease the activity of anti-apoptotic $\beta$-catenin $(51,52)$. In this study, no changes in the Bcl-2 protein level in A549 tumor lysates between the treatment groups were observed, although a significant increase in Bax expression was observed in tumor lysates harvested from mice treated with sunitinib in combination with docetaxel or with docetaxel and $1,24(\mathrm{OH})_{2} \mathrm{D}_{3}$. Sunitinib has been shown to induce the expression of pro-apoptotic proteins (Bax, Bak and PUMA) and to inhibit the expression of anti-apoptotic proteins (Bcl-2) in HL-60 and KG-1 leukemia cells (53). Nishikawa et al demonstrated that PC3 prostate cancer cells, with a decreased expression of Akt1, were more sensitive to sunitinib and expressed higher levels of Bax (54). Uzu et al demonstrated that sunitinib activated Bax in H28-T mesothelioma cells transfected with the $\mathrm{Cx} 43$ conexin gene (transmembrane protein involved in rapid intercellular communication), which resulted in the induction of apoptosis in those cells (55). Therefore, the influence of sunitinib on the expression of proteins engaged in apoptosis differs depending on the cell type and other additional factors.

Differential mechanisms involved in the effects of vitamin $D$ analogs in combination with TKIs and cytostatic drugs on cell death. According to the results of this study, a more potent anti-proliferative activity of TKIs combined with cytostatics against A549 cells correlated mostly with an increased percentage of cells in the $\mathrm{G}_{2} / \mathrm{M}$ phase of the cell cycle and with an increased percentage of cells in the sub- $\mathrm{G}_{1}$ phase. Cells arrested at a specific phase of the cell cycle could then be directed towards cell death. Apoptosis, one of the most frequently studied types of cell death, is regulated by many factors and can proceed primarily through intrinsic or extrinsic pathways. The common elements of these pathways are initiator caspases (caspase-2, caspase-8, caspase-9, or caspase-10) and executioner caspases (caspase-3, caspase-6, and caspase-7). Caspase-3 is the most important executioner caspase, activated by any of the initiator caspases $(56,57)$. In this study, incubation of the A549 lung cancer cells with imatinib and docetaxel alone or in combination resulted in an increase in caspase-3 activity. The tested vitamin D compounds decreased the activity of the protease that was induced by imatinib or imatinib in combination with cisplatin or docetaxel. Koren et al demonstrated that $1,25(\mathrm{OH})_{2} \mathrm{D}_{3}$ decreased caspase-3 activity in HT-29 colon cancer cells treated with $\mathrm{H}_{2} \mathrm{O}_{2}$, whereas it increased caspase-independent cytotoxicity (58). In turn, $1,25(\mathrm{OH})_{2} \mathrm{D}_{3}$ has been shown to 
protect keratinocytes against osmotic shock-, oxidative stress-, or TNF $\alpha$-induced apoptosis (59). In this study, despite the decreased activity of caspase- 3 in A549 cells by vitamin D compounds used in combination with imatinib, we did not find a decrease in the percentage of dead cells (as assessed by the analysis of the sub- $\mathrm{G}_{1}$ population). This indicates that vitamin $\mathrm{D}$ did not reduce the cytotoxicity of imatinib; therefore, following incubation with imatinib in combination with $1,24(\mathrm{OH})_{2} \mathrm{D}_{3}$ or $1,25(\mathrm{OH})_{2} \mathrm{D}_{3}$ there was caspase-independent cell death, which was not due to apoptosis.

In this study, sunitinib and cisplatin did not influence caspase-3 activity. Furthermore, we found that caspase-3 activity was lower when sunitinib was combined with docetaxel than when the cells were exposed to docetaxel alone. In this case, cell death was found to be caspase-independent. Lavallard et al demonstrated that imatinib induced the apoptosis of Bcr-Ablpositive leukemia cells by increasing caspase- 3 activity. They also demonstrated that despite the inhibition of caspase with specific caspase inhibitor using imatinib, there was excessive cell death, which suggests that it was caspase-independent cell death (60). Costa et al demonstrated using neuroblastoma cells that the silencing of miR-21 expression sensitized the cells to the cytotoxicity of sunitinib. After the expression of miR-21 was silenced, treatment with sunitinib resulted in an increase in caspase-3 activity compared to the cells treated with sunitinib without miR-21 silencing. In addition, as a result of miR-21 silencing, the upregulation of p21 expression, and therefore p53 activation were observed (61). Moreover, miR-21 is often overexpressed in cancer, including NSCLC, for example, in the A549 cell line $(62,63)$. Therefore, the inability of sunitinib to induce caspase-3 activity in A549 cells may result from the overexpression of miR-21. In addition, when sunitinib was used in combination with cisplatin, an increase in caspase- 3 activity was observed. Treatment of the A549 cells with cisplatin has been shown to result in the downregulation of miR-21 expression (64). In this regard, an increase in caspase-3 activity after combined use with sunitinib with cisplatin may be associated with a decreased level of miR-21.

Following inappropriate mitosis of the cell (incorrect chromosomal segregation, invalid centrosome duplication) in response to DNA damage, mitotic cell death or the so-called mitotic catastrophe can occur. The examples of mitotic catastrophe inducers are agents that cause hyperpolarization, for example, taxanes (docetaxel), or the depolarization of microtubules, for example, vinca alkaloids (vincristine) and colchicine. Cells that are formed are larger in size than normally dividing cells and are multinucleated $(56,65)$. In this study, the death of the A549 lung cancer cells treated with docetaxel alone or with docetaxel in different combinations with TKIs and vitamin D compounds was a result of mitotic catastrophe. DAPI staining of the A549 cells revealed the appearance of multi-nucleated cells. Opinions differ about the prerequisite of caspases for the occurrence of mitotic catastrophe. In cells proceeding through mitotic catastrophe, the final stage of death may occur through apoptosis or necrosis (65). Therefore, cells treated with docetaxel in combination with sunitinib, in which we did not observe caspase-3 activity, may die through necrosis.

Factors determining the sensitivity of A549 lung cancer cells to vitamin $D$ analogs. A549 lung cancer cells were resistant to the test vitamin D compounds in vitro: incubation of the A549 lung cancer cells with $1,24(\mathrm{OH})_{2} \mathrm{D}_{3}$ or $1,25(\mathrm{OH})_{2} \mathrm{D}_{3}$ for $72 \mathrm{~h}$ did not result in the inhibition of proliferation. $1,25(\mathrm{OH})_{2} \mathrm{D}_{3}$ reveals its activity through VDR; therefore, the expression of VDR was analyzed in different types of normal and cancer cells to determine whether they are sensitive to the anti-proliferative activity of $1,25(\mathrm{OH})_{2} \mathrm{D}_{3}$. It was shown that a lower level of VDR correlated with cancer progression, whereas a higher level of VDR and a higher serum 25-hydroxyvitamin $\mathrm{D}_{3}$ concentration positively correlated with the survival of patients suffering from lung adenocarcinoma (66). In this study, the A549 lung cancer cells expressed VDR; however, the level of its expression was not significantly altered even after treatment with different combinations of the test compounds, apart from treatment with docetaxel which resulted in the downregulation of VDR. Even if VDR is expressed in some cells, the activity of the receptor depends on its appropriate structure, which in turn, is determined by the gene sequence. Few polymorphisms of $V D R$ are known, and some of these can correlate with a greater response for $1,25(\mathrm{OH})_{2} \mathrm{D}_{3}$; for example, osteoblasts stimulated with $1,25(\mathrm{OH})_{2} \mathrm{D}_{3}$ have been shown to secrete different amounts of osteocalcin depending on the inherited $V D R$ allele $(67,68)$. The correlation between $V D R$ polymorphism and the risk of lung cancer has also been the subject of many studies (69-72); however, to date, the literature in this field indicates that the TaqI allele may be the risk factor in lung cancer development, whereas in other studies, it was assumed that this allele may be a protective factor. These conflicting data may be due the different numbers of studied populations, the criteria of analysis, different genetic backgrounds, and others $(69,70)$. There are also alternative to the VDR nuclear receptors, that have been shown to bind derivatives of vitamin $\mathrm{D}$, such as the retinoid acid-related orphan receptors (RORs) $\alpha$ and $\gamma$. RORs have been shown to regulate a number of physiological processes, such as embryonic development, differentiation, immune response and metabolism (73-75). The expression levels of RORs are downregulated and/or hypoactivated in breast cancer or melanoma compared to normal tissue and RORs have also been identified as tumor suppressors $(74,76)$. Vitamin D derivatives have been shown to act as antagonists or inverse agonists of RORs, but $1,25(\mathrm{OH})_{2} \mathrm{D}_{3}$ to some degree only. There are other potent ligands of RORs, that are novel non-calcemic vitamin $\mathrm{D}$ derivatives produced by CYP11A1 hydroxylase, such as $20(\mathrm{OH}) \mathrm{D} 3$ and $20,23(\mathrm{OH})_{2} \mathrm{D}_{3}$, which in turn act as partial agonists of VDR (77-80). However, to date, at least to the best of our knowledge, there are no available studies regarding the role of RORs in the anticancer activity of vitamin D derivatives in lung cancer.

The lack of the response of A549 cells to the anti-proliferative activity of $1,24(\mathrm{OH})_{2} \mathrm{D}_{3}$ and $1,25(\mathrm{OH})_{2} \mathrm{D}_{3}$ may be due to the inactivation of vitamin $\mathrm{D}$ compounds by 24-hydroxylase CYP24. Zhang et al demonstrated the correlation between mutation present in lung cancer cells (KRAS and EGFR) and the level of VDR and CYP24 expression. Cells with KRAS mutation (e.g., A549) expressed low levels of VDR and high levels of CYP24, whereas cells with EGFR mutation (e.g., HCC827) expressed high levels of VDR and low levels of CYP24. Therefore, the authors of that study concluded that patients with lung cancer with EGFR mutations can be treated with vitamin $\mathrm{D}(81)$. In this study, western blot analysis revealed 
that A549 cells following incubation with $1,24(\mathrm{OH})_{2} \mathrm{D}_{3}$ or $1,25(\mathrm{OH})_{2} \mathrm{D}_{3}$ expressed higher levels of CYP24, whereas the highest level of CYP24 expression was observed in cells treated with imatinib in combination with vitamin D compounds and/ or with cisplatin or docetaxel. CYP24 is sometimes recognized as an oncogene as it is often overexpressed in tumors and a high level of CYP24 enzyme inactivates $1,25(\mathrm{OH})_{2} \mathrm{D}_{3}$, which in turn limits its availability, and as a result its anti-proliferative, prodifferentiation and pro-apoptotic activity. Therefore, the use of other compounds, which can inhibit CYP24 activity, together with $1,25(\mathrm{OH})_{2} \mathrm{D}_{3}$ has also been investigated (82-84). For example CTA091, an inhibitor of CYP24, has been shown to enhance the anti-proliferative activity of $1,25(\mathrm{OH})_{2} \mathrm{D}_{3}$ against H292, A549, and HCC827 lung cancer cells (85). In the present study, we demonstrated that the use of vitamin D compounds with sunitinib and/or with docetaxel did not increase the expression of CYP24 in vitro. Furthermore, in in vivo A549 mouse model, it was observed that the level of CYP24 expression in tumors harvested from mice treated with sunitinib in combination with $1,24(\mathrm{OH})_{2} \mathrm{D}_{3}$ and docetaxel was the lowest compared to other groups, which could be the reason for the best antitumor effect achieved.

Anti-angiogenic mechanisms of action of vitamin D analogs in combination with TKIs and cytostatic drugs. The improved activity of sunitinib in combination with $1,24(\mathrm{OH})_{2} \mathrm{D}_{3}$ in the A549 lung cancer model may have resulted due to the influence of vitamin D analog on endothelial cells. A previous study using tumor-derived endothelial cells (TDECs) demonstrated that $1,25(\mathrm{OH})_{2} \mathrm{D}_{3}$ arrested cells in the $\mathrm{G}_{0} / \mathrm{G}_{1}$ phase of the cell cycle and induced apoptosis. Following treatment with $1,25(\mathrm{OH})_{2} \mathrm{D}_{3}$, the expression of VDR in these cells increased, and the VDR signaling pathway was activated (86). In in vivo studies, VDR knockout (KO) mice have been shown to have tumors with differing vessel structure from VDR wild-type mice. The vessels of KO-VDR mice were enlarged, surrounded with less pericytes, and tumors harvested from KO-VDR mice contained higher levels of pro-angiogenic factors, such as HIF-1 $\alpha$, VEGF, angiopoietin 1 (Ang1) and PDGF-BB (17). In this study $1,25(\mathrm{OH})_{2} \mathrm{D}_{3}$ and $1,24(\mathrm{OH})_{2} \mathrm{D}_{3}$ inhibited the proliferation of HLMECs and arrested the cells in the $G_{0} / G_{1}$ phase of the cell cycle. The tested vitamin $\mathrm{D}$ compounds enhanced the cytotoxic activity of imatinib, sunitinib, cisplatin and docetaxel, shifting the interaction of the test agents towards synergism.

$1,24(\mathrm{OH})_{2} \mathrm{D}_{3}$ and $1,25(\mathrm{OH})_{2} \mathrm{D}_{3}$ also improved the induction of caspase-3 activity by cisplatin or docetaxel in HLMECs. TKIs (sunitinib or imatinib) used alone did not activate caspase-3 and did not improve the activity of the tested cytostatics in the induction of the protease, but when vitamin D compounds were added to the combination of a given TKI with cytostatic drugs, the observed caspase-3 activity was higher than that of cytostatic compounds (cisplatin or docetaxel) used in combination only with vitamin D compounds. The increased activity of caspase-3 following incubation of the HLMECs with sunitinib, cytostatic and $1,24(\mathrm{OH})_{2} \mathrm{D}_{3}$, or $1,25(\mathrm{OH})_{2} \mathrm{D}_{3}$ correlated with an increased percentage of cells in the sub- $\mathrm{G}_{1}$ phase, suggesting that the cell death was a result of apoptosis. The role of VEGF in endothelial cells is to protect them from apoptosis (87). Therefore, in this study, suppressing VEGFR activity by sunitinib additionally increased the response of HLMECs to the cytotoxic effects of cisplatin or docetaxel in combination with vitamin $\mathrm{D}$ compounds.

Role of p53 protein in the regulation of tumor angiogenesis. Cancer cells, including lung cancer cells, produce a number of growth factors engaged in tumor angiogenesis, for example, VEGF (88). Uncontrolled angiogenesis is in turn associated with cancer progression. One of the mechanisms involved in the regulation of angiogenesis is p53, for example, through the regulation of growth factor expression; the downregulation of pro-angiogenic factors, for example, VEGF; and the upregulation of anti-angiogenic factor expression. Tumors with mutant p53 are more vascularized than those of wild-type p53 (25). Kieser et al demonstratd that murine fibroblasts NIH3T3, expressing mutant p53 constantly, produced high level of VEGF (89), whereas Mukhophadhyay et al demonstrated that wild-type p53 decreases the activity of VEGF promoter (90). Studies have also shown that there is a correlation between mutant p53 and the level of VEGF in NSCLC (91-93). A number of studies have aimed at inducing p53 pathway to activate the processes regulated by $\mathrm{p} 53$ protein (cell cycle arrest, apoptosis, DNA damage repair, autophagy, gene transcription regulation etc.) (94). In this study, we assessed the effects of TKIs, cytostatics and vitamin D compounds and their combinations on VEGF-A production by A549 cells in vitro and correlated with the changes in p53 expression. The results demonstrated that sunitinib and cisplatin downregulated VEGF-A protein expression, and the combination of both even multiplied the effect. At the mRNA level, treatment with sunitinib upregulated VEGFA mRNA expression compared to untreated cells. In addition, the decrease in the protein level may not have been undergone at the transcription level but may be by the processes of protein translation, posttranslational modification, or excessive protein degradation. There was also no correlation between the downregulation of VEGF-A and p53 expression as after treatment of A549 cells with sunitinib, we did not observe p53 expression. Calero et al demonstrated that sunitinib downregulated the secretion of VEGF by SK-N-BE(2) neuroblastoma cells. The authors stated that the decrease in VEGF expression correlated with PI3K/Akt signaling pathway inhibition by sunitinib followed by increased MYC protein degradation (24). MYC has also been shown to regulate the expression of VEGF and other angiogenic factors. However, according to cell type the regulation may differ at the level of transcription or post-translational modifications and also may be determined by different physiological and pathological factors (95). In this study, we observed that after sunitinib treatment, the level of MYC mRNA in A549 cells increased (the expression of MYC at the protein level was not analyzed yet). Mahalingam et al did not observe any changes in c-MYC protein level in Caki-1 or 786-O kidney cancer cells following treatment with sunitinib. However, after c-MYC expression was silenced by siRNA or PIM-1 kinase inhibitor (the function of PIM-1 is to stabilize c-MYC protein through phosphorylation), the cells became more sensitive to sunitinib (96). In this study, we observed the downregulation of MYC mRNA expression following treatment of the A549 cells with cisplatin. In the study by Xie et al, treatment with cisplatin resulted in a decrease in MYC protein expression in 
the A549 cells compared to the control cells (97). Therefore, the use of cisplatin in combination with sunitinib may sensitize A549 lung cancer cells to sunitinib.

The function of $\mathrm{p} 53$ protein is regulated at the level of transcription, translation, stabilization and post-translational modifications. The other important issue for p53 activity is its localization inside the cell, that is, when a stress factor affects the cell, p53 protein should be transferred to the nucleus to induce the transcription of given target genes. However, in some types of cancer with wild-type p53, its activity is inhibited by arresting it in the cytoplasm or excessive export from the nucleus, and thus, it renders cancer cells resistant to radio- or chemotherapy (98). In this study, as shown in Fig. 11, following incubation of the A549 lung cancer cells with cisplatin or docetaxel alone or with the tested TKIs and/or vitamin D compounds, p53 protein was localized in the nucleus, where it plays the role of transcription factor (p21 expression level increased as assessed by western blot analysis).

The activity of $\mathrm{p} 53$ protein is regulated by MDM2 protein (the human protein is often termed HDM2), which inhibits the transcriptional activity of $\mathrm{p} 53$ through binding with $\mathrm{N}$-terminal domain, or induces p53 export from nucleus, or due to E3 ubiquitin ligase activity, HDM2 directs p53 to proteasomal degradation. Moreover, HDM2 and p53 are linked through an autoregulatory negative feedback loop. One of the concepts in recovering p53 activity is the inhibition of the p53-HDM2 interaction $(99,100)$. In a kidney cancer model, sunitinib revealed only transient anticancer activity and temporarily increased the expression of p53 and p $21^{\text {waf1 }}$, and additionally, increased the expression of HDM2, while tumors developed resistance to sunitinib. Only after using MI-319, a HDM2 antagonist, a better effectiveness of sunitinib was observed (101). In this study, in A549 lung cancer cells incubated with sunitinib, the expressoin of TP53 mRNA increased; however, we did not observe an increased level of p53 protein. Probably, despite of the induction of TP53 expression, newly formed protein can be rapidly ubiquitinated by HDM2 and degraded. Only when sunitinib was applied together with cisplatin or docetaxel, we observed an increase in the $\mathrm{p} 53$ protein level: the cytostatics activated DNA damage response mechanisms that in turn induced the upregulation of $\mathrm{p} 53$ protein expression; $\mathrm{p} 53$ was then translocated to the nucleus and induced p21 protein expression. Gan et al demonstrated that docetaxel stabilized p53 protein in LNCaP prostate cancer cells. Treatment of LNCaP cells with docetaxel resulted in the upregulation of p53 and p21 and the downregulation of HDM2. The increase in p53 level did not result from elevated TP53 transcription as there was no increase in mRNA observed. When the authors measured the half-life of p53, they demonstrated that as a result of docetaxel treatment the half-life increased from $2 \mathrm{~h}$ to more than $8 \mathrm{~h}$ (102). In this study, treatment of the A549 cells with docetaxel also did not increase TP53 mRNA, whereas the level of p53 protein increased significantly. In A549 cells, docetaxel may stabilize $\mathrm{p} 53$ protein by affecting HDM2 activity.

The analysis of the VEGF-A level in A549 tumor lysates harvested from mice treated with different combinations of sunitinib, docetaxel and $1,24(\mathrm{OH})_{2} \mathrm{D}_{3}$ indicated that sunitinib and $1,24(\mathrm{OH})_{2} \mathrm{D}_{3}$ used alone or in combination decreased the VEGF-A level in A549 tumors, whereas in tumors harvested from mice treated with sunitinib in combination with docetaxel, the expression was found to be slightly low compared to that of the control mice. We also analyzed the expression of the tumor suppressor PTEN, and we observed its increase in tumor lysates from mice treated with $1,24(\mathrm{OH})_{2} \mathrm{D}_{3}$ or $1,24(\mathrm{OH})_{2} \mathrm{D}_{3}$ in combination with docetaxel. $1,25(\mathrm{OH})_{2} \mathrm{D}_{3}$ and 19-nor-1,25(OH) $)_{2} \mathrm{D}_{2}$ (paricalcitol) have been shown to induce PTEN expression in leukemia cell lines (103). PTEN through the PI3K/Akt pathway influences the process of angiogenesis. Ma et al demonstrated that silencing PTEN in pancreatic cancer cells resulted in the upregulation of VEGF (104). Therefore, a low level of VEGF-A in tumors harvested from mice treated with $1,24(\mathrm{OH})_{2} \mathrm{D}_{3}$ may result from the upregulation of PTEN expression.

Mechanisms of acquired resistance to anticancer therapy. One of the important obstacles in anticancer therapy is the acquired resistance of the tumor to the applied treatment. In case of anti-VEGF therapy, the resistance involves the activation of alternative signaling pathways engaged in angiogenesis that are independent of the VEGF pathway. Therefore, combining drugs with different mechanisms of action and aiming at multiple signaling pathways may provide a more effective control of tumor angiogenesis $(25,105,106)$. For example, the use of sunitinib in the treatment of kidney cancer leads to acquired resistance after a few months since the therapy is introduced. The suggested mechanisms of resistance to sunitinib are as follows: the activation of angiogenic signaling pathways, resistance of cells of tumor microenvironment, increased invasiveness of cancer cells and acquisition the ability to metastasis, activation of alternative signaling pathways, incomplete inhibition of drug targets, or the changes in expression of some microRNAs (107). Huang et al explored serum harvested from mice xenografted with kidney cancer sensitive or resistant to sunitinib and ascertained significantly elevated IL-8 level in serum from mice with sunitinib resistant kidney cancer. After the application of IL-8 neutralizing antibody, they observed sensitization of the tumor to sunitinib (108). IL-8 expression is regulated, among other things, by NF- $\mathrm{KB}(109,110)$. In this study using a A549 lung cancer model, we observed an upregulation in NF- $\kappa B$ expression in tumors harvested from mice treated with sunitinib, with the highest level of NF- $\mathrm{\kappa B}$ and simultaneously the lowest level of I $\kappa \mathrm{B}$ in those receiving triple combination of sunitinib,

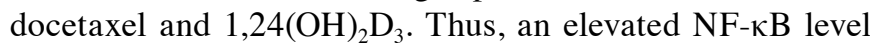
may be associated with the activation of alternative signaling pathways after treatment with sunitinib. NF- $\mathrm{kB}$ is an important mediator of lung carcinogenesis. Efforts are being made to inhibit the activity of NF- $\mathrm{kB}$ or for application in cancer chemoprevention that can also affect the NF- $\mathrm{BB}$ pathway. However, there are some doubts regarding the validity of this concept due to undesired side-effects resulting from the violation of immune system function. In addition, it turned out that NF- $\kappa \mathrm{B}$ may reveal distinct activity depending on the cell or tissue type (111). For example, the increased survival of neuronal cells has been shown to correlate with the upregulation of NF- $\mathrm{\kappa B}$ expression following treatment with sunitinib (112). Other studies disclosed the double role of NF- $\mathrm{KB}$ in the regulation of apoptosis. Depending on the cell type and external stimulus influencing on the cell, NF- $\mathrm{kB}$ may induce or inhibit apoptosis (113). Aoki et al showed that increased activity of NF- $\mathrm{KB}$ may be connected with hypoxia-induced endothelial cells apoptosis. In these cells 
authors observed increase in the ratio of $\mathrm{Bax}$ to $\mathrm{Bcl}-2$ and higher level of p53 (114). NF- $\kappa$ B may play a role in the regulation of p53 expression in response to different stress factors, as it was discovered that the $\mathrm{NF}-\kappa \mathrm{B}$ binding region in TP53 promoter overlaps genotoxic stress response region (115). NF- $\kappa \mathrm{B}$ stimulates the expression of genes inducing apoptosis for example, Fas and Fas-ligand. In response to UV-C or daunorubicine, $\mathrm{NF}-\kappa \mathrm{B}$ downregulates the expression of anti-apoptotic Bcl-xL, and thus under some circumstances the activation of $\mathrm{NF}-\kappa \mathrm{B}$ sensitizes cells to programmed cell death (116). Therefore, in this study, the increased NF- $\kappa \mathrm{B}$ expression level in A549 tumors obtained from mice treated with the triple combination of sunitinib, docetaxel and $1,24(\mathrm{OH})_{2} \mathrm{D}_{3}$ may have contributed to the induction of apoptosis in tumors, particularly since the simultaneously increased expression of pro-apoptotic Bax was observed.

In this study, $1,24(\mathrm{OH})_{2} \mathrm{D}_{3}$ used alone slightly decreased $\mathrm{NF}-\kappa \mathrm{B}$ level in A549 tumors compared to the controls, but it did not lower the level of NF- $\kappa \mathrm{B}$ that was upregulated by sunitinib. $1,25(\mathrm{OH})_{2} \mathrm{D}_{3}$ has been found to modulate the immune response, for example, through the influence on activity of NF- $\mathrm{NB}$ in lymphocytes, fibroblasts and monocytes. $1,25(\mathrm{OH})_{2} \mathrm{D}_{3}$ induces the expression of $\mathrm{I} \kappa \mathrm{B} \alpha$ in macrophages and peripheral blood mononuclear cells and also inhibits the expression of pro-inflammatory cytokines, for example IL-8 in prostate cancer cells through interaction with $\mathrm{NF}-\kappa \mathrm{B}$ signaling. The inhibition of $\mathrm{NF}-\kappa \mathrm{B}$ activity by $1,25(\mathrm{OH})_{2} \mathrm{D}_{3}$ may be achieved through the blocking of p65 subunit translocation to nucleus, and in this manner, the binding with target DNA sequences, for example, $I L-8$ promoter, is inhibited. Another possible mechanism of $N F-\kappa B$ inhibition by $1,25(\mathrm{OH})_{2} \mathrm{D}_{3}$ is the induction of the expression of proteins that interfere with $\mathrm{NF}-\kappa \mathrm{B}$, for example, insulin-like growth factor binding protein IGFBP-3 (117). The analysis of the IL-8 level in A549 tumors may clarify if the level of the IL- 8 was downregulated or not despite the upregulation of $N F-\kappa B$.

In conclusion, the results of this study provide new knowledge of the combination of drugs with different mechanisms of action in an A549 lung cancer model in vitro and in vivo. The tested TKIs exhibited differential mechanisms of induction of cell death: imatinib induced caspase-dependent, whereas sunitinib induced caspase-independent cell death. $1,24(\mathrm{OH})_{2} \mathrm{D}_{3}$ and $1,25(\mathrm{OH})_{2} \mathrm{D}_{3}$ augmented caspase activity only in HLMECs. Sunitinib and cisplatin decreased the secretion of VEGF-A from A549 cells via a p53-independent and p53-dependent pathway, respectively. Moreover, to the best of our knowledge, we demonstrated for the first time the use and the efficacy of the triple combination of sunitinib, docetaxel and $1,24(\mathrm{OH})_{2} \mathrm{D}_{3}$ in an A549 lung cancer model, which showed that $1,24(\mathrm{OH})_{2} \mathrm{D}_{3}$ enhanced the anticancer activity of TKI sunitinib and sunitinib in combination with docetaxel in a NSCLC A549 model in vivo. The observed anticancer activity may be the result of the influence of tested agents on the process of tumor angiogenesis, for example, through the downregulation of VEGF-A expression in tumor or through direct influence on the proliferation of endothelial cells, and also on the induction of cell death inside the tumor. The use of sunitinib and docetaxel in combination with $1,24(\mathrm{OH})_{2} \mathrm{D}_{3}$ downregulates CYP24 expression, which may result in the decreased inactivation of vitamin $\mathrm{D}$ analog inside the tumor and its greater availability as a consequence.

\section{Acknowledgements}

This study was supported by a grant from the Polish National Science Center (NCN)-No. 2013/09/N/NZ4/01720. Publication supported by Wroclaw Center of Biotechnology within a Program 'The Leading National Research Center (KNOW)' for 2014-2018.

\section{References}

1. Adler I: Primary Malignant Growths of the Lungs and Bronchi; A Pathological and Clinical Study. Longmans, Green, New York, NY, 1912.

2. Debakey M: Carcinoma of the lung and tobacco smoking: A historical perspective. Ochsner J 1: 106-108, 1999.

3. Proctor RN: The history of the discovery of the cigarette-lung cancer link: Evidentiary traditions, corporate denial, global toll. Tob Control 21: 87-91, 2012.

4. Dubey AK, Gupta U and Jain S: Epidemiology of lung cancer and approaches for its prediction: A systematic review and analysis. Chin J Cancer 35: 71, 2016.

5. Siegel RL, Miller KD and Jemal A: Cancer statistics, 2016. CA Cancer J Clin 66: 7-30, 2016.

6. Gadgeel SM, Ramalingam SS and Kalemkerian GP: Treatment of lung cancer. Radiol Clin North Am 50: 961-974, 2012.

7. Feldman D, Krishnan AV, Swami S, Giovannucci E and Feldman BJ: The role of vitamin D in reducing cancer risk and progression. Nat Rev Cancer 14: 342-357, 2014.

8. Slominski AT, Brożyna AA, Zmijewski MA, Jóźwicki W, Jetten AM, Mason RS, Tuckey RC and Elmets CA: Vitamin D signaling and melanoma: Role of vitamin $\mathrm{D}$ and its receptors in melanoma progression and management. Lab Invest 97: 706-724, 2017.

9. Higashimoto Y, Ohata M, Nishio K, Iwamoto Y, Fujimoto $\mathrm{H}$ Uetani K, Suruda T, Nakamura Y, Funasako M and Saijo N: 1 alpha, 25-dihydroxyvitamin D3 and all-trans-retinoic acid inhibit the growth of a lung cancer cell line. Anticancer Res 16 (5A): 2653-2659, 1996.

10. Güzey M, Sattler C and DeLuca HF: Combinational effects of vitamin D3 and retinoic acid (all trans and 9 cis) on proliferation, differentiation, and programmed cell death in two small cell lung carcinoma cell lines. Biochem Biophys Res Commun 249: 735-744, 1998.

11. Young MRI, Ihm J, Lozano Y, Wright MA and Prechel MM: Treating tumor-bearing mice with vitamin D3 diminishes tumorinduced myelopoiesis and associated immunosuppression, and reduces tumor metastasis and recurrence. Cancer Immunol Immunother 41: 37-45, 1995

12. Young MRI, Lozano Y, Ihm J, Wright MA and Prechel MM: Vitamin D3 treatment of tumor bearers can stimulate immune competence and reduce tumor growth when treatment coincides with a heightened presence of natural suppressor cells. Cancer Lett 104: 153-161, 1996.

13. Norton R and O'Connell MA: Vitamin D: Potential in the prevention and treatment of lung cancer. Anticancer Res 32: 211-221, 2012.

14. Mernitz H, Smith DE, Wood RJ, Russell RM and Wang XD: Inhibition of lung carcinogenesis by 1 alpha,25-dihydroxyvitamin D3 and 9-cis retinoic acid in the A/J mouse model: Evidence of retinoid mitigation of vitamin D toxicity. Int J Cancer 120: 1402-1409, 2007.

15. Yudoh K, Matsuno $H$ and Kimura T: 1alpha,25-dihydroxyvitamin D3 inhibits in vitro invasiveness through the extracellular matrix and in vivo pulmonary metastasis of B16 mouse melanoma. J Lab Clin Med 133: 120-128, 1999.

16. Ben-Shoshan M, Amir S, Dang DT, Dang LH, Weisman Y and Mabjeesh NJ: 1alpha,25-dihydroxyvitamin D3 (Calcitriol) inhibits hypoxia-inducible factor-1/vascular endothelial growth factor pathway in human cancer cells. Mol Cancer Ther 6: 1433-1439, 2007.

17. Chung I, Han G, Seshadri M, Gillard BM, Yu WD, Foster BA, Trump DL and Johnson CS: Role of vitamin D receptor in the antiproliferative effects of calcitriol in tumor-derived endothelial cells and tumor angiogenesis in vivo. Cancer Res 69: 967-975, 2009.

18. Bao BY, Yao J and Lee YF: 1alpha, 25-dihydroxyvitamin D3 suppresses interleukin-8-mediated prostate cancer cell angiogenesis. Carcinogenesis 27: 1883-1893, 2006. 
19. Crino L and Metro G: Therapeutic options targeting angiogenesis in nonsmall cell lung cancer. Eur Respir Rev 23: 79-91, 2014.

20. McMahon G: VEGF receptor signaling in tumor angiogenesis. Oncologist 5 (Suppl 1): 3-10, 2000.

21. Sandler A, Yi J, Dahlberg S, Kolb MM, Wang L, Hambleton J, Schiller J and Johnson DH: Treatment outcomes by tumor histology in Eastern Cooperative Group Study E4599 of bevacizumab with paclitaxel/carboplatin for advanced non-small cell lung cancer. J Thorac Oncol 5: 1416-1423, 2010.

22. Sandler A, Gray R, Perry MC, Brahmer J, Schiller JH, Dowlati A, Lilenbaum R and Johnson DH: Paclitaxel-carboplatin alone or with bevacizumab for non-small-cell lung cancer. N Engl J Med 355: 2542-2550, 2006

23. Aggarwal C, Somaiah N and Simon G: Antiangiogenic agents in the management of non-small cell lung cancer: Where do we stand now and where are we headed? Cancer Biol Ther 13: 247-263, 2012

24. Calero R, Morchon E, Johnsen JI and Serrano R: Sunitinib suppress neuroblastoma growth through degradation of MYCN and inhibition of angiogenesis. PLoS One 9: e95628, 2014.

25. Teodoro JG, Evans SK and Green MR: Inhibition of tumor angiogenesis by p53: A new role for the guardian of the genome. J Mol Med (Berl) 85: 1175-1186, 2007.

26. Wietrzyk J, Nevozhay D, Filip B, Milczarek M and Kutner A: The antitumor effect of lowered doses of cytostatics combined with new analogs of vitamin D in mice. Anticancer Res 27 (5A): 3387-3398, 2007.

27. Wietrzyk J, Nevozhay D, Milczarek M, Filip B and Kutner A: Toxicity and antitumor activity of the vitamin D analogs PRI-1906 and PRI-1907 in combined treatment with cyclophosphamide in a mouse mammary cancer model. Cancer Chemother Pharmacol 62: 787-797, 2008.

28. Milczarek M, Rosinska S, Psurski M, Maciejewska M, Kutner A and Wietrzyk J: Combined colonic cancer treatment with vitamin D analogs and irinotecan or oxaliplatin. Anticancer Res 33: 433-444, 2013.

29. Milczarek M, Psurski M, Kutner A and Wietrzyk J: Vitamin D analogs enhance the anticancer activity of 5-fluorouracil in an in vivo mouse colon cancer model. BMC Cancer 13: 294, 2013.

30. Milczarek M, Filip-Psurska B, Swiętnicki W, Kutner A and Wietrzyk J: Vitamin D analogs combined with 5-fluorouracil in human HT-29 colon cancer treatment. Oncol Rep 32: 491-504, 2014.

31. Maj E, Filip-Psurska B, Switalska M, Kutner A and Wietrzyk J: Vitamin D analogs potentiate the antitumor effect of imatinib mesylate in a human A549 lung tumor model. Int J Mol Sci 16: 27191-27207, 2015.

32. Trynda J, Turlej E, Milczarek M, Pietraszek A, Chodyński M, Kutner A and Wietrzyk J: Antiproliferative activity and in vivo toxicity of double-point modified analogs of 1,25-dihydroxyergocalciferol. Int J Mol Sci 16: 24873-24894, 2015.

33. Kieda C, Paprocka M, Krawczenko A, Załecki P, Dupuis P, Monsigny M, Radzikowski C and Duś D: New human microvascular endothelial cell lines with specific adhesion molecules phenotypes. Endothelium 9: 247-261, 2002.

34. Nevozhay D: Cheburator software for automatically calculating drug inhibitory concentrations from in vitro screening assays. PLoS One 9: e106186, 2014.

35. McDaid HM and Johnston PG: Synergistic interaction between paclitaxel and 8-chloro-adenosine 3',5'-monophosphate in human ovarian carcinoma cell lines. Clin Cancer Res 5: 215-220, 1999.

36. Chou TC: Drug combination studies and their synergy quantification using the Chou-Talalay method. Cancer Res 70: 440-446, 2010.

37. Chou TC and Talalay P: Generalized equations for the analysis of inhibitions of Michaelis-Menten and higher-order kinetic systems with two or more mutually exclusive and nonexclusive inhibitors. Eur J Biochem 115: 207-216, 1981.

38. Chou TC and Talalay P: Quantitative analysis of dose-effect relationships: The combined effects of multiple drugs or enzyme inhibitors. Adv Enzyme Regul 22: 27-55, 1984

39. Ekici OD, Li ZZ, Campbell AJ, James KE, Asgian JL, Mikolajczyk J, Salvesen GS, Ganesan R, Jelakovic S, Grütter MG, et al: Design, synthesis, and evaluation of aza-peptide Michael acceptors as selective and potent inhibitors of caspases-2, -3, -6, -7, -8, -9, and -10. J Med Chem 49: 5728-5749, 2006.

40. Ramnath N, Kim S and Christensen PJ: Vitamin D and lung cancer. Expert Rev Respir Med 5: 305-309, 2011.

41. Switalska M, Nasulewicz-Goldeman A,Opolska A,Maciejewska M, Kutner A and Wietrzyk J: The in-vitro antiproliferative effect of PRI-2191 and imatinib applied in combined treatment with cisplatin, idarubicin, or docetaxel on human leukemia cells. Anticancer Drugs 23: 70-80, 2012.
42. Pan F, Tian J, Zhang X, Zhang Y and Pan Y: Synergistic interaction between sunitinib and docetaxel is sequence dependent in human non-small lung cancer with EGFR TKIs-resistant mutation. J Cancer Res Clin Oncol 137: 1397-1408, 2011.

43. Zhuravel E, Efanova O, Shestakova T, Glushko N, Mezhuev O, Soldatkina M and Pogrebnoy P: Administration of vitamin D3 improves antimetastatic efficacy of cancer vaccine therapy of Lewis lung carcinoma. Exp Oncol 32: 33-39, 2010.

44. Socinski MA, Novello S, Brahmer JR, Rosell R, Sanchez JM, Belani CP, Govindan R, Atkins JN, Gillenwater HH, Pallares C, et al: Multicenter, phase II trial of sunitinib in previously treated, advanced non-small-cell lung cancer. J Clin Oncol 26: 650-656, 2008.

45. Kerbel RS, Viloria-Petit A, Klement G and Rak J: 'Accidental' anti-angiogenic drugs. Anti-oncogene directed signal transduction inhibitors and conventional chemotherapeutic agents as examples. Eur J Cancer 36: 1248-1257, 2000.

46. Klement G, Baruchel S, Rak J, Man S, Clark K, Hicklin DJ, Bohlen P and Kerbel RS: Continuous low-dose therapy with vinblastine and VEGF receptor-2 antibody induces sustained tumor regression without overt toxicity. J Clin Invest 105: R15-R24, 2000.

47. Man S, Bocci G, Francia G, Green SK, Jothy S, Hanahan D, Bohlen P, Hicklin DJ, Bergers G and Kerbel RS: Antitumor effects in mice of low-dose (metronomic) cyclophosphamide administered continuously through the drinking water. Cancer Res 62: 2731-2735, 2002.

48. Kollmannsberger C, Soulieres D, Wong R, Scalera A, Gaspo R and Bjarnason G: Sunitinib therapy for metastatic renal cell carcinoma: Recommendations for management of side effects. Can Urol Assoc J 1 (Suppl): S41-S54, 2007.

49. Di Lorenzo G, Porta C, Bellmunt J, Sternberg C, Kirkali Z, Staehler M, Joniau S, Montorsi F and Buonerba C: Toxicities of targeted therapy and their management in kidney cancer. Eur Urol 59: 526-540, 2011.

50. Wietrzyk J, Pełczyńska M, Madej J, Dzimira S, Kuśnierczyk H, Kutner A, Szelejewski W and Opolski A: Toxicity and antineoplastic effect of (24R)-1,24-dihydroxyvitamin D3 (PRI-2191). Steroids 69: 629-635, 2004.

51. Díaz GD, Paraskeva C, Thomas MG, Binderup L and Hague A: Apoptosis is induced by the active metabolite of vitamin D3 and its analogue EB1089 in colorectal adenoma and carcinoma cells: Possible implications for prevention and therapy. Cancer Res 60: 2304-2312, 2000.

52. Pálmer HG, González-Sancho JM, Espada J, Berciano MT, Puig I, Baulida J, Quintanilla M, Cano A, de Herreros AG, Lafarga M, et al: Vitamin $\mathrm{D}(3)$ promotes the differentiation of colon carcinoma cells by the induction of E-cadherin and the inhibition of beta-catenin signaling. J Cell Biol 154: 369-387, 2001.

53. Teng CLJ, Yu CTR, Hwang WL, Tsai JR, Liu HC, Hwang GY and Hsu SL: Effector mechanisms of sunitinib-induced G1 cell cycle arrest, differentiation, and apoptosis in human acute myeloid leukaemia HL60 and KG-1 cells. Ann Hematol 92: 301-313, 2013.

54. Nishikawa M, Miyake $H$ and Fujisawa M: Enhanced sensitivity to sunitinib by inhibition of Akt1 expression in human castrationresistant prostate cancer PC3 cells both in vitro and in vivo. Urology 85: 1215.e1-1215.e7, 2015.

55. Uzu M, Sato H, Yamada R, Kashiba T, Shibata Y, Yamaura K and Ueno K: Effect of enhanced expression of connexin 43 on sunitinib-induced cytotoxicity in mesothelioma cells. J Pharmacol Sci 128: 17-26, 2015.

56. Stepień A, Izdebska M and Grzanka A: The types of cell death. Postepy Hig Med Dosw (Online) 61: 420-428, 2007 (In Polish).

57. Korwek Z and Alster O: The role of the DNA damage response in apoptosis and cell senescence. Postepy Biochem 60: 248-262, 2014 (In Polish).

58. Koren R, Wacksberg S, Weitsman GE and Ravid A: Calcitriol sensitizes colon cancer cells to $\mathrm{H}_{2} \mathrm{O}_{2}$-induced cytotoxicity while inhibiting caspase activation. J Steroid Biochem Mol Biol 101: 151-160, 2006.

59. Diker-Cohen T, Koren R, Liberman UA and Ravid A: Vitamin D protects keratinocytes from apoptosis induced by osmotic shock, oxidative stress, and tumor necrosis factor. Ann N Y Acad Sci 1010: 350-353, 2003.

60. Lavallard VJ, Pradelli LA, Paul A, Bénéteau M, Jacquel A, Auberger P and Ricci JE: Modulation of caspase-independent cell death leads to resensitization of imatinib mesylate-resistant cells. Cancer Res 69: 3013-3020, 2009.

61. Costa PM, Cardoso AL, Nóbrega C, Pereira de Almeida LF, Bruce JN, Canoll P and Pedroso de Lima MC: MicroRNA-21 silencing enhances the cytotoxic effect of the antiangiogenic drug sunitinib in glioblastoma. Hum Mol Genet 22: 904-918, 2013. 
62. Liu ZL, Wang H, Liu J and Wang ZX: MicroRNA-21 (miR-21) expression promotes growth, metastasis, and chemo- or radioresistance in non-small cell lung cancer cells by targeting PTEN. Mol Cell Biochem 372: 35-45, 2013.

63. Xu L, Huang Y, Chen D, He J, Zhu W, Zhang Y and Liu X: Downregulation of miR-21 increases cisplatin sensitivity of nonsmall-cell lung cancer. Cancer Genet 207: 214-220, 2014.

64. Zhang YX, Yue Z, Wang PY, Li YJ, Xin JX, Pang M, Zheng QY and Xie SY: Cisplatin upregulates MSH2 expression by reducing miR-21 to inhibit A549 cell growth. Biomed Pharmacother 67 : 97-102, 2013

65. Vakifahmetoglu H, Olsson M and Zhivotovsky B: Death through a tragedy: Mitotic catastrophe. Cell Death Differ 15: 1153-1162, 2008

66. Kim SH, Chen G, King AN, Jeon CK, Christensen PJ, Zhao L, Simpson RU, Thomas DG, Giordano TJ, Brenner DE, et al: Characterization of vitamin D receptor (VDR) in lung adenocarcinoma. Lung Cancer 77: 265-271, 2012.

67. Naves M, Alvarez-Hernández D, Fernández-Martín JL, Paz-Jiménez J, García-Prado P, Fernández-Coto T, Santamaría I and Cannata-Andía J: Effect of VDR gene polymorphisms on osteocalcin secretion in calcitriol-stimulated human osteoblasts. Kidney Int Suppl 63: S23-S27, 2003.

68. Alvarez-Hernandez D, Naves-Diaz M, Gomez-Alonso C, Coto E and Cannata-Andia JB: Tissue-specific effect of VDR gene polymorphisms on the response to calcitriol. J Nephrol 21: 843-849, 2008.

69. Dogan I, Onen HI, Yurdakul AS, Konac E, Ozturk C, Varol A and Ekmekci A: Polymorphisms in the vitamin D receptor gene and risk of lung cancer. Med Sci Monit 15: BR232-BR242, 2009.

70. Fu Y, Li J and Zhang Y: Polymorphisms in the vitamin D receptor gene and the lung cancer risk. Tumour Biol 35: 1323-1330, 2014.

71. Wu X, Cheng J and Yang K: Vitamin D-related gene polymorphisms, plasma 25-hydroxy-vitamin $\mathrm{D}$, cigarette smoke and non-small cell lung cancer (NSCLC) risk. Int J Mol Sci 17: 20 2016.

72. Vaughan-Shaw PG, O'Sullivan F, Farrington SM, Theodoratou E, Campbell H, Dunlop MG and Zgaga L: The impact of vitamin D pathway genetic variation and circulating 25-hydroxyvitamin D on cancer outcome: Systematic review and meta-analysis. Br J Cancer 116: 1092-1110, 2017.

73. Slominski AT, Kim TK, Takeda Y, Janjetovic Z, Brozyna AA, Skobowiat C, Wang J, Postlethwaite A, Li W, Tuckey RC, et al: $\mathrm{ROR} \alpha$ and ROR $\gamma$ are expressed in human skin and serve as receptors for endogenously produced noncalcemic 20-hydroxyand 20,23-dihydroxyvitamin D. FASEB J 28: 2775-2789, 2014.

74. Brożyna AA, Jóźwicki W, Skobowiat C, Jetten A and Slominski AT: ROR $\alpha$ and ROR $\gamma$ expression inversely correlates with human melanoma progression. Oncotarget 7: 63261-63282, 2016.

75. Slominski AT, Kim TK, Hobrath JV, Oak ASW, Tang EKY Tieu EW, Li W, Tuckey RC and Jetten AM: Endogenously produced nonclassical vitamin D hydroxy-metabolites act as 'biased' agonists on VDR and inverse agonists on ROR $\alpha$ and ROR $\gamma$. J Steroid Biochem Mol Biol 173: 42-56, 2017.

76. Du J and Xu R: ROR $\alpha$, a potential tumor suppressor and therapeutic target of breast cancer. Int J Mol Sci 13: 15755-15766, 2012.

77. Slominski AT, Kim TK, Shehabi HZ, Semak I, Tang EKY Nguyen MN, Benson HAE, Korik E, Janjetovic Z, Chen J, et al: In vivo evidence for a novel pathway of vitamin D-3 metabolism initiated by P450scc and modified by CYP27B1. FASEB J 26: 3901-3915, 2012.

78. Slominski AT, Kim TK, Shehabi HZ, Tang EKY, Benson HAE, Semak I, Lin Z, Yates CR, Wang J, Li W, et al: In vivo production of novel vitamin D2 hydroxy-derivatives by human placentas, epidermal keratinocytes, Caco-2 colon cells and the adrenal gland. Mol Cell Endocrinol 383: 181-192, 2014

79. Slominski AT, Kim TK, Li W, Postlethwaite A, Tieu EW, Tang EKY and Tuckey RC: Detection of novel CYP11A1-derived secosteroids in the human epidermis and serum and pig adrenal gland. Sci Rep 5: 14875, 2015.

80. Slominski AT, Kim TK, Li W and Tuckey RC: Classical and non-classical metabolic transformation of vitamin D in dermal fibroblasts. Exp Dermatol 25: 231-232, 2016.

81. Zhang Q, Kanterewicz B, Shoemaker S, Hu Q, Liu S, Atwood K and Hershberger P: Differential response to $1 \alpha, 25-$ dihydroxyvitamin $\mathrm{D} 3(1 \alpha, 25(\mathrm{OH}) 2 \mathrm{D} 3)$ in non-small cell lung cancer cells with distinct oncogene mutations. J Steroid Biochem Mol Biol 136: 264-270, 2013.
82. Mimori K, Tanaka Y, Yoshinaga K, Masuda T, Yamashita K, Okamoto M, Inoue $\mathrm{H}$ and Mori M: Clinical significance of the overexpression of the candidate oncogene CYP24 in esophageal cancer. Ann Oncol 15: 236-241, 2004.

83. Horváth HC, Lakatos P, Kósa JP, Bácsi K, Borka K, Bises G, Nittke T, Hershberger PA, Speer G and Kállay E: The candidate oncogene CYP24A1: A potential biomarker for colorectal tumorigenesis. J Histochem Cytochem 58: 277-285, 2010.

84. Luo W, Hershberger PA, Trump DL and Johnson CS: 24-Hydroxylase in cancer: Impact on vitamin D-based anticancer therapeutics. J Steroid Biochem Mol Biol 136: 252-257, 2013.

85. Zhang Q, Kanterewicz B, Buch S, Petkovich M, Parise R, Beumer J, Lin Y, Diergaarde B and Hershberger PA: CYP24 inhibition preserves 1 $\alpha, 25$-dihydroxyvitamin $\mathrm{D}(3)$ anti-proliferative signaling in lung cancer cells. Mol Cell Endocrinol 355: 153-161, 2012.

86. ChungI,Yu WD,Karpf AR,Flynn G,BernardiRJ,ModzelewskiRA, Johnson CS and Trump DL: Anti-proliferative effects of calcitriol on endothelial cells derived from two different microenvironments. J Steroid Biochem Mol Biol 103: 768-770, 2007.

87. Spyridopoulos I, Brogi E, Kearney M, Sullivan AB, Cetrulo C, Isner JM and Losordo DW: Vascular endothelial growth factor inhibits endothelial cell apoptosis induced by tumor necrosis factor-alpha: Balance between growth and death signals. J Mol Cell Cardiol 29: 1321-1330, 1997.

88. Aonuma M, Iwahana M, Nakayama Y, Hirotani K, Hattori C, Murakami K, Shibuya M and Tanaka NG: Tumorigenicity depends on angiogenic potential of tumor cells: Dominant role of vascular endothelial growth factor and/or fibroblast growth factors produced by tumor cells. Angiogenesis 2: 57-66, 1998.

89. Kieser A, Weich HA, Brandner G, Marmé D and Kolch W: Mutant p53 potentiates protein kinase $C$ induction of vascular endothelial growth factor expression. Oncogene 9: 963-969, 1994.

90. Mukhopadhyay D, Tsiokas L and Sukhatme VP: Wild-type p53 and v-Src exert opposing influences on human vascular endothelial growth factor gene expression. Cancer Res 55: 6161-6165, 1995.

91. Niklińska W, Burzykowski T, Chyczewski L and Nikliński J: Expression of vascular endothelial growth factor (VEGF) in non-small cell lung cancer (NSCLC): Association with p53 gene mutation and prognosis. Lung Cancer 34 (Suppl 2): S59-S64, 2001.

92. Fontanini G, Boldrini L, Vignati S, Chinè S, Basolo F, Silvestri V, Lucchi M, Mussi A, Angeletti CA and Bevilacqua G: Bcl2 and p53 regulate vascular endothelial growth factor (VEGF)mediated angiogenesis in non-small cell lung carcinoma. Eur J Cancer 34: 718-723, 1998.

93. Yuan A, Yu CJ, Luh KT, Kuo SH, Lee YC and Yang PC: Aberrant p53 expression correlates with expression of vascular endothelial growth factor mRNA and interleukin- 8 mRNA and neoangiogenesis in non-small-cell lung cancer. J Clin Oncol 20: 900-910, 2002.

94. Brown CJ, Lain S, Verma CS, Fersht AR and Lane DP Awakening guardian angels: Drugging the p53 pathway. Nat Rev Cancer 9: 862-873, 2009.

95. Sundaram P, Dang CV and Thomas-Tikhonenko A: Myc and control of tumor neovascularization. In: Cancer Genome and Tumor Microenvironment. Thomas-Tikhonenko A (ed). Springer, New York, NY, pp167-187, 2010.

96. Mahalingam D, Espitia CM, Medina EC, Esquivel JA II, Kelly KR, Bearss D, Choy G, Taverna P, Carew JS, Giles FJ, et al: Targeting PIM kinase enhances the activity of sunitinib in renal cell carcinoma. Br J Cancer 105: 1563-1573, 2011

97. Xie C, Pan Y, Hao F, Gao Y, Liu Z, Zhang X, Xie L, Jiang G, Li $Q$ and Wang E: C-Myc participates in $\beta$-catenin-mediated drug resistance in A549/DDP lung adenocarcinoma cells. APMIS 122: 1251-1258, 2014

98. O'Brate A and Giannakakou P: The importance of p53 location Nuclear or cytoplasmic zip code? Drug Resist Updat 6: 313-322, 2003.

99. Levine AJ and Oren M: The first 30 years of p53: Growing ever more complex. Nat Rev Cancer 9: 749-758, 2009.

100. Patel S and Player MR: Small-molecule inhibitors of the p53-HDM2 interaction for the treatment of cancer. Expert Opin Investig Drugs 17: 1865-1882, 2008.

101. Panka DJ, Liu Q, Geissler AK and Mier JW: Effects of HDM2 antagonism on sunitinib resistance, p53 activation, SDF-1 induction, and tumor infiltration by $\mathrm{CD} 11 \mathrm{~b}^{+} / \mathrm{Gr}-1^{+}$myeloid derived suppressor cells. Mol Cancer 12: 17, 2013. 
102. Gan L, Wang J, Xu H and Yang X: Resistance to docetaxelinduced apoptosis in prostate cancer cells by $\mathrm{p} 38 / \mathrm{p} 53 / \mathrm{p} 21$ signaling. Prostate 71: 1158-1166, 2011.

103. Kumagai T, O'Kelly J, Said JW and Koeffler HP: Vitamin D2 analog 19-nor-1,25-dihydroxyvitamin D2: Antitumor activity against leukemia, myeloma, and colon cancer cells. J Natl Cancer Inst 95: 896-905, 2003.

104. Ma J, Sawai H, Ochi N, Matsuo Y, Xu D, Yasuda A, Takahashi H, Wakasugi $\mathrm{T}$ and Takeyama $\mathrm{H}$ : PTEN regulates angiogenesis through PI3K/Akt/VEGF signaling pathway in human pancreatic cancer cells. Mol Cell Biochem 331: 161-171, 2009.

105. Clarke JM and Hurwitz HI: Understanding and targeting resistance to anti-angiogenic therapies. J Gastrointest Oncol 4: 253-263, 2013.

106. Giuliano S and Pagès G: Mechanisms of resistance to antiangiogenesis therapies. Biochimie 95: 1110-1119, 2013.

107. Joosten SC, Hamming L, Soetekouw PM, Aarts MJ, Veeck J, van Engeland $\mathrm{M}$ and Tjan-Heijnen VC: Resistance to sunitinib in renal cell carcinoma: From molecular mechanisms to predictive markers and future perspectives. Biochim Biophys Acta 1855 : $1-16,2015$.

108.Huang D, Ding Y, Zhou M, Rini BI, Petillo D, Qian CN, Kahnoski R, Futreal PA, Furge KA and Teh BT: Interleukin- 8 mediates resistance to antiangiogenic agent sunitinib in renal cell carcinoma. Cancer Res 70: 1063-1071, 2010.

109. Wysoczynski M, Shin DM, Kucia M and Ratajczak MZ: Selective upregulation of interleukin- 8 by human rhabdomyosarcomas in response to hypoxia: Therapeutic implications. Int J Cancer 126: 371-381, 2010.

110. Hoesel B and Schmid JA: The complexity of NF- $\kappa$ B signaling in inflammation and cancer. Mol Cancer 12: 86, 2013.
111. Chen W, Li Z, Bai L and Lin Y: NF-kappaB in lung cancer, a carcinogenesis mediator and a prevention and therapy target. Front Biosci (Landmark Ed) 16: 1172-1185, 2011.

112. Sanchez A, Tripathy D, Yin X, Luo J, Martinez JM and Grammas P: Sunitinib enhances neuronal survival in vitro via $\mathrm{NF}-\kappa \mathrm{B}-$ mediated signaling and expression of cyclooxygenase-2 and inducible nitric oxide synthase. J Neuroinflammation 10: 93, 2013.

113. Barkett $\mathrm{M}$ and Gilmore TD: Control of apoptosis by Rel/ NF-kappaB transcription factors. Oncogene 18: 6910-6924, 1999.

114. Aoki M, Nata T, Morishita R, Matsushita H, Nakagami H, Yamamoto K, Yamazaki K, Nakabayashi M, Ogihara T and Kaneda Y: Endothelial apoptosis induced by oxidative stress through activation of NF-kappaB: Antiapoptotic effect of antioxidant agents on endothelial cells. Hypertension 38: 48-55, 2001.

115. Royds JA, Dower SK, Qwarnstrom EE and Lewis CE: Response of tumour cells to hypoxia: Role of p53 and NFkB. Mol Pathol 51: 55-61, 1998 .

116. Perkins ND and Gilmore TD: Good cop, bad cop: The different faces of NF-kappaB. Cell Death Differ 13: 759-772, 2006.

117. Krishnan AV and Feldman D: Molecular pathways mediating the anti-inflammatory effects of calcitriol: Implications for prostate cancer chemoprevention and treatment. Endocr Relat Cancer 17: R19-R38, 2010.

This work is licensed under a Creative Commons Attribution-NonCommercial-NoDerivatives 4.0 International (CC BY-NC-ND 4.0) License. 